\title{
DRUMMOND'S
}

OBSER VAT I O N

\section{NATURAL SYSTEMS}

OF BOTANY.

Three Shillings. 


$$
209301
$$

Panntan 

Digitized by the Internet Archive in 2017 with funding from Wellcome Librąry 


\section{OBSERVATIONS}

ON

NATURAL SYSTEMS

OF

BOTANY. 
LONIONN :

SrotriswuUde and SHAw, New-street-Square. 


\section{OBSERVATIONS}

ON

\section{NATURAL SYSTEMS}

\section{BOTANY.}

PROFESSOR OF ANATOMY AND PHYSIOLOGY IN THE ROYAI. PELFAST INSTITUTION;

ALTHOR OT

"FIRST STEPS TO BOTANY," "I.ETTERS TO A TOUNG NATURATIST," " mirst steps to Anatomy," etc.

\section{LONDON:}

LONGMAN, BROWN, GREEN, AND IONGMANS, PATERNOSTER-ROW. 


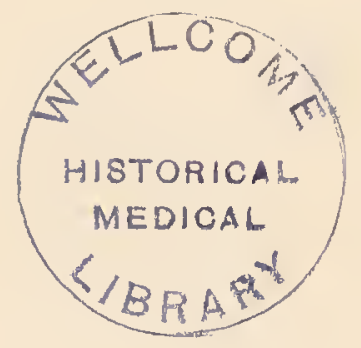

"It has been the fashion in modern times, to depreciate the discoveries of Linnæus, and to put forward other eminent naturalists as rivals for popular favour at his expense. Nothing can be more unjust towards the memory of departed greatness, nothing can be less acceptable to existing merit, than the attempt to build up their fame by disparaging that of another."

Magazine of Nat. Hist. vol. i. p. 10. 


\section{OBSERVATIONS}

ox

\section{NATURAL SYSTEMS OF BOTANY.}

WHeN the Linnaan system of botany came to be understood, (and from its simplicity and clearness, this took place in a wonderfully short period of time,) it was enthusiastically embraced by almost every botanist in the civilised world, and in no country, perhaps, more cordially than in England. So beautiful, indeed, so manageable, and so attractive was it, that thousands became attached to the pursuit of botanical science, who, but for it, would never have spent a thought upon the subject. It became a favourite occupation with the learned, and indeed of the comparatively unlearned, to examine flowers, and refer them to their classes and orders, and finally, through this easy introduction, to ascertain their names and history; and thus a love of nature was increased, or generated, to an extent before unknown. The love of plants may almost be considered as inherent 
in woman's nature, and here was a key by which what was before admired, could now be understood; by which, without other assistance, the gentler sex could ascertain what the plants were which occurred in their daily walks, and by which they could soon become acquainted with the vegetable productions of the groves, and fields, and woods around them. To every ramble was thus superadded a source of pleasure before unknown, and numerous plants hitherto overlooked, or disregarded, assumed an interest and importance before unthought of. So attractive, indeed, was botany thus rendered, that not only were there many female botanists, but female authors, who conferred great benefits on the science, more especially in enlarging our knowledge of the Algæ or sea-weeds. There is, however, I am sorry to say, little of this now; the enthusiasm is gone, and the culture of the science among the female sex has become, I am much afraid, almost extinct.

I believe that this has arisen chiefly from an idea, promulgated far and wide, that the system of Linnæus, being an artificial one, should be abandoned, and what has been called the Jussieuan, or Natural System, adopted in its place. But the great and important question ought to be, I conceive, what system is best calculated for leading the student to a knowledge of such plants as he may wish to examine; and this is easily answered, 
for there never was, nor perhaps ever can be, invented, a method that will so completely answer such an end as the system laid down by Linnæus. All former methods sank into insignificance before it; and although it is the fashion of the present day to vilify, ridicule, and speak of it as useless, I greatly fear that, until it again comes into favour, and obtains the countenance it deserves, Botany, as a popular pursuit, will become as dead a letter as it was before the system of Linnæus engaged the attention, and struck with admiration and delight almost all the naturalists of Europe.

I have not myself, for many years, been attending to botanical pursuits, except occasionally by fits and starts, and then in a great measure for the purpose of renewing the delightful feelings I experienced, when young, in learning my early lessons from Priscilla Wakefield's introduction to the science; and what has principally urged me to write the present observations is the hope that, however feeble the effort may be, it may have some effect in assisting to excite similar feelings in the mind of the young botanist, by attracting him, if possible, to study the only easy method of gaining a knowledge of plants that has ever been the offspring of human genius.

According to an aphorism of Linnæus, the great and important step in understanding any science is to know things themselves. How can we 
reasun about plants unless we know what these plants are? We must first have a knowledge of the things we speak, or write, or think, or philosophise about, before we can do any of these to a good purpose, and, therefore, the most useful and important introduction to any science is that which leads us fairly to a knowledge of the things themselves. Here the Linnæan system is pre-eminent over all other introductions to a knowledge of plants; but what good thing has there ever been that has not had its enemies, and how often does its very excellence raise against it a host of dissentients? In allusion to the Linnæan system, one of the most laborious and learned botanists of our own times observes that this system, though "well adapted to captivate the superficial inquirer" - " yet exercises so baneful an influence upon Botany, as to have rendered it doubtful whether it even deserved a place among the sciences." Now this passage, which would aim a death-blow at the system of Linnæus, seems to me, though intended otherwise, to be highly complimentary. Every beginner, in the study of any science whatever, must necessarily be a superficial inquirer, and whatever system is "well adapted to captivate" him to its farther prosecution must, indeed, be highly valuable, and I believe that in $n o$ science can there be found any introduction, at all to be compared in this respect to the botanical 
system of Linnæus. But if it captivate the superficial inquirer to enter on the study of plants, does it follow that his inquiries are to be afterwards of a superficial nature? Was Linnæus a superficial inquirer? or Hudson, or Lightfoot, or Sir J. E. Smith, or Turner, or Templeton, or Sir W. Hooker, or Dr. Greville? And how many others might be named, all of the Linnæan school, by whose labours the Botany of these islands has been more completely elucidated than that, perhaps, of any country in the world!

In the second edition of Dr. Lindley's book on the Natural System of Botany, published in 1836, the author says in the Preface, page vii. "In the first edition of this work I entered into some explanation of the fallacy of the common opinion that the artificial system of Linnæus is easy, and the natural system difficult of application. Within the last five or six years, however, the sentiments of the public have undergone so great a change upon this subject, that I no longer find it necessary to go into such details."

That it has become the fashion to cry up what is called the natural system, for the purpose of suppressing the comparatively easy and efficient system of Linnæus, is but too true, and the consequence is, as already stated, that botanical pursuits, except amongst those who choose to devote a lifetime to them, have fallen into general neglect. In an Is 3 
excellent review in the Dublin Quarterly Journal of Medical Science for February 1848, of a work lately published by Dr. Steele, entitled "A Handbook of Field Botany," I find the following corroboration of what I now advance :- "Dr. Steele may mean, when speaking of the advanced and advancing state of botanical science, that botany is becoming popular amongst the masses - that it is a favourite study of the million. We regret that we must dissent from this opinion. We venture to assert that botany was much more popular in Dublin forty, or even eighty years ago, than it is now. The members of the Medico-Physical, and other societies of the former period, had an herbcollector, and frequent mention is made in their Transactions of rare plants brought to them for inspection. They were in the habit of going out on herbarizing excursions; and Dr. Rutty thought it, in one instance, a great grievance that a sufficient number did not attend on one of these occasions. What chance would we have, at the present day, of getting half a dozen members of the Royal Irish Academy to attend an herbarizing excursion? And be it remembered this Medico-Physical Society numbered in its ranks the first physicians and surgeons of the day. We are informed by our respected friend, Mr. Mackay, of the many pleasant tours having a botanical object, in which, some forty years ago, he accompanied Dr. Whit- 
ley Stokes, Dr. Percival, and other eminent men of that period. Ah ! we beg to assure Dr. Steele that botany is not advanced or advancing in popularity."

What is here said of Dublin may, I am afraid, be applied to most other parts. In Belfast, which has gained some credit for the culture of natural history, especially through the late Mr. Templeton, and my esteemed friend William Thompson, Esq., I am not aware that there is a single person attending to botany, with the exception of some medical students, and their teacher, in the Royal Institution. That such a change should have taken place with regard to this beautiful science, I can only account for by attributing it, principally at least, to the assiduously repeated assertions that Linnæan botany is of no value. Dr. Lindley has written so much in its disparagement, and so highly extolled the natural system, that, without sufficient inquiry, the conclusion has become almost unavoidable that it is worthless: this author, indeed, exults in its entire overthrow, and observes that "fifteen years have sufficed to render the once popular, but superficial and useless system of Linnæus a mere matter of history." * And yet this same writer states in the preface to his "School Botany," that "whatever the future intention of a student of botany may be, it is in-

* Vegetable Kingdom, Preface.

B 4 
dispensable that the first step to be taken should be that of gaining an acquaintance with the common plants of his own country. In the absence of that, he cannot make a single move in advance. He must first master the rudiments of the science, and master them correctly. This little book has been prepared for the purpose of enabling him to do so."* Now I have no hesitation in saying that this little book never will do so; let it be compared with any introduction to Linnæan botany, and it will be apparent as noon-day, that, with the object mentioned in view, the latter is beyond all comparison its superior. Read Rose's or Hull's Elements, or Lee's or Sir J. Smith's Introduction, or the first volume of Withering's Arrangement, or Rousseau's Letters, or Priscilla Wakefield, and the superiority of all or any of them, in imparting the rudiments of botanical knowledge, and, what is of not less importance, in imbuing the student with a love for the science, will be clearly seen; whereas I firmly believe that Dr. Lindley's "School Botany" must have the very opposite tendency.

After taking considerable pains to comprehend the natural system, as it is called, I have not been able to find out one single advantage which it possesses ; it contradicts itself at every turn, is full

* School Botany, Preface, p. iv. 
of misrepresentation, and so far from being natural, brings together into the same orders plants possessed of the most different qualities and appearance. We are candidly enough, indeed, told that, of this system, "Nature herself who creates species only, knows nothing. Our genera, orders, classes and the like, are mere contrivances to facilitate the arrangements of our ideas with regard to species. A genus, order or class, is therefore called natural, not because it exists in nature, but because it comprehends species naturally resembling each other more than they resemble anything else." *

Of these resemblances I will give some examples from Dr. Lindley's "Vegetable Kingdom;" but these, let it be observed, are only a small sample from a multitude, as I will refer only to such plants as almost every one is familiar with. We all know a rose, and we are equally well acquainted with the strawberry; but few persons, I apprehend, would say that they "resemble each other more than they do anything else," or that they should belong to a family of plants called natural. They belong, however, to the order Rosacex, as do many others as unlike roses as can be imagined, and among these is the meadowsweet, which has no more resemblance to a rose

* Lindley's Nat. Syst. of Botany, 2d ed., Preface. 
than it has to a beech-tree. Heath is not very like a rhododendron, yet by the magic power of the natural system, the heaths, rhododendrons, azaleas, and arbutuses are all domesticated together in one family or order, along with others as unlike each other as possible; and so it is with almost every one of the 303 orders described in the "Vegetable Kingdom." In the order Primulacex we have the primrose, the cyclamen, and the water violet. In Ranunculacex, we find united in similar bonds the butter-cup, the traveller's joy, the anemone, the hellebore, and the marsh-marigold, which do bear some similarity to each other; but then, along with these plants, we have the columbine, the larkspur, the aconite, and the peony, which an uninitiated person would pronounce to be very unlike to those preceding. The butter-cup and the larkspur have certainly little resemblance to each other. In the other orders we find similar anomalies throughout; the snow-drop, united with the American aloe-the lily, with the asparagus and butcher's broom the lupin and trefoil, with the laburnum - the privet, with the ash - the potato, with capsicum and the deadly night-shade - the beautiful little speedwell (veronica), with the tall shepherd's club, snapdragon, globe-flowered buddlea, eyebright, yellow-rattle, and digitalis. But it is unnecessary to point out any more of these most 
unnatural combinations, and I will only further observe that the honeysuckle meets in the same order with the laurustinus and the elder.

Supposing that the latter plants, and others in the order in which they have been placed, had a considerable number of certain characters in their structure independent of their outward appearance, there might be some shadow of reason for connecting them together; but here, and throughout the whole system, uncertainty and discrepancies are predominant. To illustrate this I will copy from the "Vegetable Kingdom" the description given of this order, (the Caprifolia of Jussieu, Caprifoliaceæ of Richard, and Lonicereæ of Endlicher, ) and mark in italics the discrepancies I allude to; but I must observe that much more striking examples of this ordered disorder might be selected.

"Shrubs or herbaceous plants with opposite leaves, destitute of stipules. Flowers usually corymbose, and often sweet-scented. Calyx superior, 4-5-cleft, usually with two or more bracts at its base. Corolla superior monopetalous, or polypetalous, rotate or tubular, regular or irregular. Stamens epipetalous, equal in number to the lobes of the corolla, and alternate with them. Ovary with from 1 to 5 cells, one of which is often 1-seeded, the others being many-seeded; in the former the ovule is pendulous; style 1 ; 
stigmas 3 or 5 . Fruit indehiscent, 1 or morecelled, either dry, fleshy or succulent, crowned by the persistent lobe of the calyx. Seeds either solitary and pendulous, or numerous and attached to the axis; testa often bony; embryo very small, in fleshy albumen; radicle next the hilum.

"As left by Jussieu, this order was a heterogeneous assemblage; as altered and better limited, it seems to be less objectionable. It possesses a striking affinity with Cinchonads," \&c. But why go on farther with this series of learned puzzles which can lead to nothing but doubts and darkness?

One, if not the most prominent, advantage arising from this natural system is stated to be, that all the species of any one natural order of plants are possessed of similar properties; that if we know the qualities of any one of these species, we may calculate with confidence on those qualities or properties being the same in all the other species of the same order; and on this subject Dr. Lindley speaks very decidedly. "This science," he says, (that is the natural system, " it is which teaches the physician how to discover in every region the medicines that are best adapted for the maladies that prevail in it; and which, by furnishing him with a certain clue to the knowledge of the tribes in which particular properties are, or are not to be found, renders him as much at ease alone, and seemingly without resources, 
in a land of unknown herbs, as if he were in the midst of a magazine of drugs in some civilised country." Nearly the same thing has been repeated by this author in his other works + ; but supposing it to be true, which it is not, still it would be of little avail, as not one in a hundred of the medical men in our navy or army care any thing about botany; though there can be no doubt that every physician and surgeon, whether in the service or not, should possess a certain degree of botanical knowledge. Still, however, botany "has no skill in surgery," and every hour which its pursuit would detain the student from his paramount duties of attending hospital, and studying disease, would be much more disadvantageous than beneficial; a good botanist may be a very ignorant practitioner, and the best physicians or surgeons in the world be very ignorant of botany. Every professor of botany, to be sure, will trumpet forth to his students the incalculable advantages attending the cultivation of that science; but the text of all professors is of a complexion with that of the currier in the besieged town, and would, mutatis mutandis, have it believed that "there is nothing like leather." Still every

* Introduction to Botany, Preface, p. vi.

$\dagger$ In preface to 1 st and $2 d$ editions of Introduction to the Natural System, and of the Vegetable Kingdom. 
medical practitioner should be well acquainted, at least with the plants common in his own neighbourhood, and this he can readily be, by adopting the easy system of Linnæus.

We may conceive a case to occur two or three times in a century, in which an army surgeon, on a foreign station, would be desirous of a substitute for one of his medicines that had run short, say the Peruvian bark. Now, among the trees of the country he was in, there might be one or more of the species which produce this bark, and, if any thing of a botanist, and having a Linnæan Flora, he would without much trouble ascertain the genus, and then he would, to a certain degree, be sure of his object, for all the species of the genus Cinchona of Linnæus possess, more or less powerfully, the same properties.

But we are told that in the natural system all the plants included in the same order are possessed of similar properties. "The advantages (says Dr. Lindley) of the natural system in applying botany to useful purposes are immense, especially to medical men, who depend so much upon the vegetable kingdom for their remedial agents. A knowledge of the properties of one plant enables the practitioner to judge scientifically of the qualities of other plants naturally allied to it, and therefore the physician, acquainted with the natural system of botany, may direct his inquiries, when 
on foreign stations, not empirically, but upon fixed principles into the qualities of the medicinal plants which have been provided in every region for the alleviation of the maladies peculiar to it. $\mathrm{He}$ is thus enabled to read the hidden characters with which nature has labelled all the hosts of species that spring from her teeming bosom. Every one of these bears inscribed upon it the uses to which it may be applied, the dangers to be apprehended from it, or the virtues with which it has been endowed. The language in 'which they are written, is not indeed human, it is in the living hieroglyphics of the Almighty, which the skill of man is permitted to interpret. The key to their meaning lies enveloped in the folds of the natural system, and is to be found in no other place." *

This is a very high eulogium on the natural system, and, according to it, all the plants contained in the order to which the Peruvian bark belongs ought to possess the same febrifuge, and other qualities. This order in Dr. Lindley's work is termed Cinchonaceæ (anglified, or vulgarised rather, into Cinchonads). The order is very large, containing trees, shrubs and herbs, and includes most of the plants belonging to Jussieu's Rubiaceæ, and is the long-named order Lygo-

* Vegetable Kingdom, Preface, p. viii. 
dysodeaceæ of Bartling's Ordines Naturales Plantarum. Dr. Lindley states (Veg. Kingd. p. 762.) that many of the plants in this order are very valuable as "tonics, febrifuges, emetics, or purgatives." These surely are very opposite properties, and the physician, depending on the above eulogium, might find to his cost, or at least his patient might chance to do so, that little dependence should be placed in the supposed similarity of properties of different plants belonging to the order of which the Cinchona forms the type. But we are told farther of the same order, that "other species, having their secretions in a state of great concentration, prove to be formidable poisons." (p. 762.) Some, however, have "properties analogous to those of Cinchona," viz. the Portlandia hexandria, and Coutarea speciosa, \&c.; but then again, Ophiorhiza Mungos, of the same order, "is so intensely bitter that the plant is called by the Malays earth-gall." The emetic ipecacuanha also belongs to it, and "Sir R. Schomburgk assures us that Indians have been poisoned by using the wood of Evosimia corymbosa to make spits for roasting meat on." What a valuable substitute for Peruvian bark! Some plants of the order are used for poisoning fish, some for destroying rats and mice, others are used for dying, and to it the coffee shrub belongs; and such are the opposite and discordant qualities of the plants belonging 
to this natural, but which many in their simplicity might consider most unnatural, order, and that opinion would not be lessened by what we are farther told concerning it, viz. "The fragrance or beauty of some of the plants of this order, especially of the Gardenias, Hindsias, Posoquerias, Ixoras, Cinchonas, Bouvardias, Catesbreas, \&c., is unsurpassed in the vegetable kingdom, and forms a strange contrast with the Spermacoces, Richardsonias, \&c., which are amongst the meanest weeds we know." Very strange, certainly, and may be considered as unnatural as strange.

The plants contained in this order are not the only ones possessing the properties of Peruvian bark. Thus, in Dr. Lindley's $232 \mathrm{~d}$ order, Loganiaceæ, p. 602., he tells us that the Strychnos pseudo-quina "is universally employed instead of Cinchona, and is asserted to be fully equal to Peruvian bark in the cure of the intermittents of Brazil." But then, as is stated in the same page, the dreadfully poisonous nux vomica is the produce of another species of Strychnos, while the famous Wooraly or Ourali poison is prepared from another, the Strychnos toxifera. The same author informs us, that "from the bark of the root of Strychnos Tieuté, another frightful poison is prepared in Java ;" but he adds that, notwithstanding this, other plants of the order are used in medicine with advantage. 
And this is the natural system which is to teach us the properties of all the plants belonging to any order whatever, if we can only find the key by ascertaining the qualities of any one species belonging to it. For my own part, I must say that I can scarcely find a single order of the flowering plants which is not a heterogeneous and incongruous assemblage, and there is scarcely one of them that is not far better calculated to puzzle, bewilder, and disgust the student, than to enlighten him. To a beginner in botany this boasted natural system is, and necessarily must be, almost if not entirely useless. There is not, and never can be, any system deserving the title of natural; for, even as Dr. Lindley himself admits, Nature knows nothing but species, and the only use that any system can be of is, that it may lead the student or inquirer to a knowledge of species, for which purpose that of Linnæus (and it pretended to nothing farther, though it accomplished more, is the most valuable and efficient that has ever been contrived. I will have more than one occasion to advert to this subject, and by doing so I trust that my remarks may have some little influence in stemming the torrent of learned mystery that is orerwhelming all popular taste for botanical science, and making the latter little better than a system of free-masonry that can only be made arailable, if at all, by the favoured few, who, with 
every advantage of gardens, nurseries, libraries and museums, make it the sole business of their lives.

But supposing that there should be any good reason for adopting the system of Jussieu as applied to the vegetable world at large, there cannot be the slightest that I can imagine for adopting it in the arrangement, either of a local Flora, or one comparatively limited, such as that of either Great Britain or Ireland; yet such is the influence of fashion, that various Floras of this description have been published, yet not altogether perhaps from fashion alone, but probably in a great measure from fear, since so great has been the senseless outcry against Linnæan botany, that an author continuing to adopt it at the present day, would run every risk of being considered as behind what would be called the present advanced state of botanical science, and his book be accordingly condemned.

In 1847, Dr. Steele, Lecturer on Botany in the Richmond Hospital School of Medicine and Surgery, published his "Handbook of Field Botany, comprising the flowering plants and ferns indigenous to the British Isles, arranged according to the natural system." There has been so much boasting of the advantages of this natural system in almost every work written to explain it, that people are led into the belief that it must possess superior advantages to any other, and even

$$
\text { c } 2
$$


blindly to think that it will easily lead to a knowledge of plants. Dr. Steele, accordingly, following his leader, Dr. Lindley, says, "In preparing the following pages for publication, I have been desirous to supply the student in botany with a guide to the floral productions of the British Isles, which, arranged according to the principles of the natural system, should embrace all that might be found necessary to enable him to identify species with ease and certainty." * Now it seems to me a most extraordinary infatuation that writers will continue to maintain the delusion, that this system is a natural one, and more extraordinary still, that it will enable the student "to identify species with ease and certainty." I do not believe that a plan could be invented, though done for the express purpose, that would more effectually be productive of difficulty and uncertainty, or that could by its difficulties more effectually deter the student from the study of botany, or give him a dislike to that science. I do believe that the socalled natural system has gained its popularity (if that can be called popularity, which is limited to a very small portion of the community, ) by an unceasing practice of puffing itself, and condemning every thing but itself.

In the review of Dr. Steele's book already mentioned, the reviewer gives a very good illus- 
tration of the easy steps by which the student is to arrive at a knowledge of plants, before he can find out the order, genus, or species of one not previously seen. He must first ascertain its order. ${ }^{6}$ But it is said (observes the reviewer), we can simplify the investigation by which we can assign a plant to its natural order; and how is this to be done? By forming an analysis of the vegetable kingdom upon some few differential characters; by requiring the student to interrogate the plant, in what may be called a dichotomous manner, through a great number of questions. For example: if the learner take up the common Seacatch-fly, and wishes to ascertain what family it belongs to, he has, first, to observe whether it be a flowering plant: secondly, whether it be a tree, or shrub, with distinct bark, wood, and pith, or an herb; whether the leaves are branch-ribbed or straight-ribbed, whether the flowers be tertiary, or sextenary, or not: thirdly, he will have to see whether the flowers have both stamens and pistils: fourthly, whether the ovary be inferior or superior: fifthly, whether the corolla be apopetalous or synpetalous : sixthly, he will have to determine whether the petals are, or are not larger than the sepals: seventhly, - but there is no use in fatiguing our readers. It is sufficient to say, that the student will require to proceed to fifteenthly, before he can satisfy himself that the family is that 
of the Caryophyllex; and he must subsequently determine the genus and the species." This, certainly, is no royal road to botany, though Dr. Steele, in the introduction to his book, states that it has been prepared, "merely to facilitate the labours of the young exploring botanist." * I fear that before the young explorer has acquired a knowledge of one half of the ninety-eight orders of flowering plants in the "Field Book," he will find the labour rather too much for him.

Let us now see how the young botanist is to find out the Sea-catch-fly by the Linnæan system: let him put in his pocket, when he goes to the sea-shore, the Irish Flora of Miss Bailey (now Lady Kane), published in Dublin in 1833 :- well, he finds springing up from among the stones, or rough gravel above high-water mark, a plant with handsome white flowers, which he had never before seen; he pulls one of these flowers, and by a single glance he at once knows its class and order: he sees that it has ten stamens, and belongs to the class Decandria, and that it has three styles, and therefore is in the order Trigynia. He then opens his Flora, and finds that in this class and order there are three native (Irish) genera, namely, Arenaria, Stellaria, and Silene, and he therefore knows that to one of these three, the plant he has

* Page xi。 
found must belong. In the small space of five lines and a half (page 83.), he finds the generic distinctions of the whole three - that Arenaria has its petals undivided, but the specimen in his hand has them cloven; it cannot, therefore, belong to the genus Arenaria; that the capsule of Stellaria consists of one cell, but the flower he is examining has one of three incomplete cells, and the petals have claws, and thus he is certain that it belongs to the genus Silene. Thus, without trouble, and in the shortest time, he ascertains the class, order, and genus of this, to him previously unknown plant, and now he has only to discover the species, of which there are four in the book he is consulting. Of these, one is hairy and viscid, but his plant is not so; another has ovate leaves, in his specimen they are lanceolate; and in the fourth species the stems are moss-like; and now he is certain, that of the four species his plant is the Silene maritima, or Sea-catch-fly.

How a system that is so beautiful, interesting and easy, should ever be pronounced as useless, is altogether an enigma to my plain understanding, and I am equally at a loss to account for Dr. Lindley's long and persevering abuse of it; but I have no doubt in stating my confirmed opinion that botany never can become a popular science, while beset by the innumerable difficulties, doubts and discrepancies, which the system of Jussieu 
involves. The more easily we can get to a knowledge of the plants around us, the more generally will it be cultivated as an elegant, delightful, and fascinating pursuit; but this must be acquired by other means than the dry, laborious, and frigid processes to be followed in the study of this natural unnatural system, in which nothing can be found stable enough to return the slightest recom. pense for the labour that must be bestowed upon it. Among its other boasted merits, it is said to be more philosophical than the Linnæan system; but I cannot in any way discover in what its philosophy consists, and notwithstanding all the flattering encomiums lavished upon it on this account, I must agree with Professor Rennie that "Philosophy it cannot be, in any genuine acceptation of the term." * As to each order containing plants possessed of similar medical and other properties, it is entirely a delusion, not to give it a more opprobrious name, and as to incongruities and contradictions, they are among its most striking characteristics.

One great advantage attending the study of Linnæan botany is, that not being very difficult to master and understand, the student is at every step satisfied and delighted with his progress, and the farther he advances, the more pleasure does

* Alphabet of Botany, p. 109. 
he experience. No higher praise could be bestowed on an improver of science, than to say, that he had contrived a method of rendering that plain which was before intricate, and of easy acquirement what was previously difficult; and this praise is eminently due to Linnæus, his sexual system having at once cleared away obstacles hitherto almost insuperable; and while it captivated many to the study of plants, it retained others, who feeling the difficulties of the natural system of Tournefort then generally followed, were about to abandon the study altogether, but continued to cultivate it with increased ardour, encouraged by the new views, and seeing the clear and easy road now opened to them.

The amiable and enthusiastic naturalist, Dr. Garden, who was located as a physician in South Carolina, states in a letter to Linnæus, dated March 1755, that during that time he had made daily excursions into the country, studying botany after the natural method of Tournefort, which, according to Linnæus, was the best at the time that had ever been contrived, and which was generally adopted. "But," (says Dr. Garden) "the immense labour of reducing the plants I collected into proper orders, to say nothing of the uncertainty attending the investigation of genera and species, and still more of determining varieties according to the Tournefortian system, was all 
so very tiresome, that at length my patience was exhausted, and had I not by good fortune met with your most excellent works, I might have been stopped in my progress, and might altogether have given up this most pleasing of pursuits. I had already almost yielded to this uncertainty, and want of satisfaction, when my friend Mr. Bull put your writings into my hands. These have first introduced into Botany the science of demonstration founded upon mathematical principles, and, at the same time, a sound as well as easy mode of classification." *

This I conceive to be exactly a parallel instance with what is taking place at the present time. The study of this lauded natural system is found to be so tiresome and unsatisfactory, such a process of mechanical labour, and such a tax upon the memory, while no adequate good results from it, that it is soon abandoned to the very few who have courage to pursue it, and who are so apt to plume themselves on their superior acquirements, and indulge their self-esteem, in depreciating with a frown of authority, as though they were Tritons among the minnows, all advocates and followers of the Linnæan system.

One great advantage of the latter is, that it is in itself consistent, while that of Jussieu, however

* Linnæan Correspondence, vol. i. p. 287. 
modified, is for ever changing, and every promulgator of it, by his writings, adapts it to his own ideas or fancy, and so the system of one year often differs materially from that of the preceding, and will most probably differ as much from that which is to succeed. Dr. Lindley, in the third edition of his "Natural System," and which is entitled "The Vegetable Kingdom," states that the former "was originally written in illustration of the popular system of De Candolle, but daily experience showed the insufficiency of that system, and the necessity of forming sub-divisions of the primary groups of plants higher than their socalled natural orders became so apparent, as to lead to serious attempts to carry out a plan of alliances, in imitation of a few continental writers;" and he states that these attempts were embodied in the second edition, published in 1836, that his views "were favourably received by those best able to judge of their value," which means, I suppose, by those who chose to agree with him, but that, "on the other hand, they have been severely criticised by writers who show a singular want of knowledge of the true bearing of such works. Those persons have imagined that a natural classification of plants is something which is suddenly to start into existence, perfect in all its parts, and their criticisms betray a total ignorance of the difficulties by which such a subject is surrounded." 
Preface, p. xi. Now I can conscientiously say, that, for my part, I am not one of those persons; and so far from imagining a natural classification to start suddenly into existence, I do not believe that there ever was, is, will, or can be, any classification truly deserving the name of natural; the systems hitherto fabricated, are certainly any thing but that.

It is supposed, however, that, in course of tirne, the investigations of numerous observers in this field will at length build up, at least a sufficiently, if not absolutely perfect system; but at all events, the attempts hitherto made have produced little uniformity, and each country has a system of its own adoption. Dr. Lindley himself states that since the publication of his Natural System in 1836 , his views have been in some respects altered, and adds that "this is inevitable in such a science as that of Systematic Botany, when the discovery of a few new facts, or lialf a dozen fresh genera, may instantly change the point of view from which a given object is observed." But let us admit that a system has been at last completed as near perfection as it could possibly be, and which would be quite satisfactory to all the principal botanists in Europe, ought that to be a reason for putting down another system, which, from its ease and simplicity, is calculated to attract persons of every station in life to such a love of plants, as will 
interest them at every step they take into the country, which will add a new sense, as it were, in contemplating the beauties of nature, which is capable of giving delight to the young, as well as to those who have fallen into the "sere and yellow leaf," and of beguiling into a sense of happiness the waning hours of the invalid? I know from various instances that the pursuit of Linnæan botany does so, I know also that many persons have acquired not only a love for, but an extensive knowledge of native botany from books alone, and without a syllable of any other teaching; but it seems, from what Dr. Lindley observes elsewhere, that he had no such faculty of learning what was simple and easy. "I have been always" (he says) "at issue with the Linnæan school of Botany, as to this system accomplishing even the little that it pretends to; and if I may be permitted to appeal to my own personal experience of the difficulties of a beginner who is unassisted by a tutor (and few have had fewer difficulties to contend against than myself), I should say that it is totally opposed to such a conclusion. I began with the Linnæan system, which I was taught to regard as little less than an inspired production; I had plenty of books compiled according to that system to consult, and I was fairly driven to seek refuge in the natural system from the difficulties and inconsistencies of that of Linnæus." Now I cannot attach the slight- 
est importance to this confession of the learned writer, for thousands who never had the access to books on Linnæan botany which he had, have not only found it divested of the difficulties he alludes to, but have from only the most limited number of such books, and from no teaching but what they taught, become zealous and delighted cultivators of the science. For my own part, though I advance this as a mere feather in the scale, I had no such advantages, I had no plenty of books on the subject, yet one single Linnæan lesson inspired me with a warm enthusiasm for the science. A medical friend who, during his collegiate studies had attended a botanical course, pointed out to me, in a morning's excursion, the parts of fructification in several wild flowers, and drew a slight sketch of the principles on which the Linnæan classification is founded:- I was enchanted, all was totally new to me, and I felt delighted at the prospect of being soon able to arrive at a knowledge of the plants I might find in my walks. And that naturally was all I then looked to; but instead of having plenty of books, I could only command Priscilla Wakefield's Introduction, and Birkenhout's Synopsis of the Natural History of Great Britain and Ireland, the second volume of which comprehends the Vegetable Kingdom. With these two books I became at once enamoured, and, boy as I was, the reading of them formed the 
most fascinating and delightful occupation that had ever occupied my youthful mind, and now that the lapse of years has silvered my hairs, I recall with unsubdued pleasure the remembrance of those times, and almost feel young again.

As to any inconsistencies of the Linnæan system, I consider them of but little moment; they were always acknowledged, and as applied to our own Flora, are in reality of no permanent moment. That they will sometimes cause difficulties to the student must be confessed, but they are anything but insurmountable; and it matters not what botanical system may be followed, these are inseparable; but so far as I can see, they are trivial indeed to those which, at every step, we meet with in those systems which have falsely been called natural.

While Dr. Lindley found the system of Linnæus so impracticable, he admits that its principles are clear and simple, and says, "that student must indeed be remarkably dull of apprehension, who could not master them in a day;" but because its application is in some cases not equally easy, because in fact it is not absolutely perfect, what no system on earth ever will be, he would reject it altogether, and supersede it by a system attended by ten thousand times its difficulties, and which no two systematists of the school of Jussieu understand alike. An advocate of this natural sys- 
tem states in the volume of botany, published by the Society for diffusing Useful Knowledge (p. 199.) that the system of Linnæus "is so simple that any body may master it in an hour; the names of its classes and orders generally carry with them their own explanation; the parts upon whose difference the system turns, are readily examined; and the whole scheme is so plain, as to be intelligible to the meanest capacity." That any person of the highest capacity could master it in one day, as asserted by the one writer, and much less in an hour, as stated by the other, I. cannot conceive; but the testimony of both bears me out in what I have stated, with regard to its value in the facilities which it affords for leading any one to the acquirement of a knowledge of the plants he may wish to examine.

And is this the system that should be cast off, and abandoned as "an idle weed?" Is a system that, even from its most inveterate detractors, has received the character of captivating the young inquirer to the acquirement of a love for the study of the vegetable world, to be pronounced as unworthy of regard? Before a student can be led to the knowledge of an unknown plant, must he spend his years in a dry laborious study, and load his memory like an encyclopedia, in order to dis. cover a single species? I should suppose that the facility of understanding and applying this system 
ought to be considered as the very highest commendation; and I trust that the time will yet arrive, when it will obtain that consequence of which it has been despoiled by the idle search after a natural system.

It is stated, however, that Linnæus himself was the strongest advocate for a natural system, and that is to a certain degree true; but at the same time he considered it as a thing all but hopeless, though in his time there were only known about eight thousand plants, while now there are ten times that number, and, on looking at his Fragmenta in the Philosophia Botanica, it will be evident that he would no more have dreamt of founding any such system on the nature of the seeds and seed vessels, than of constructing a system of ornithology on the eggs and nests of birds. But Linnæus never intended, that if even a natural system should be discovered, it was to supersede the sexual system, though the advocates of that called natural would gladly, even at the expense of truth, make it appear otherwise, and do sometimes even state this as an absolute fact. Thus a writer in the fifth volume of the London and Edinburgh Journal makes the following veracious remarks: "If something more than the name of a plant be to be comprehended in botanical arrangements, let us imitate the example of Linnæus, who, conscious of the inadequacy of his 
artificial system to serve the cause of genuine botany, wisely abandoned it, and devoted himself to devising a natural method, and called upon all botanists to assist in accomplishing so desirable an object. Let us no longer cling to this system which has been expelled from almost every other country of Europe, but rather let us cast it, like an idle weed, away, which cannot be suffered longer to deform the fair garden of philosophic truth." *

This assertion, with regard to Linnæus, is most absolutely false, either wilfully so, or originating in the writer's ignorance of Linnæus or his writings; and I think it very probable that he has been not less ignorant of the system of Jussieu: there has been so much boasting in praise of the latter, and so much confident assertion of its superiority, that persons, really unacquainted with any system whatever, may think themselves authorised, and that they cannot be going wrong, in depreciating that of Linnæus to the lowest state of degradation, and of sounding the praises of the Jussieuan to the very welkin. That the "immortal Swede" never for a moment thought of abandoning his sexual system, is very evident, on better authority than mine. "That natural affinities," says Mr. Roscoe, "are to be studied, and that this depart- 
ment of the science cannot be too diligently cultivated, was his decided conviction. He has even frequently contemplated the possibility of an arrangement, which should include, in their natural orders, the whole vegetable kingdom; but, in alluding to such an event, it was always as a mere possibility, of the completion of which he had scarcely a distant hope. Still less would he have been inclined to admit that any such arrangement, even if it could be formed, could supersede that which he had with so much assiduity demonstrated, and to which he invariably adhered to the close of his life. To collect together detached sentiments from his writings, for the purpose of proving that he preferred a natural method to his own, as a general arrangement, is to pervert his opinions, to render him the adversary of his own labours, and the suicide of his own fame. To the firm and inflexible conviction of the practical superiority of his own method, all the passages of these writers are strictly reconcileable; but if any doubt remained on this subject, it could readily be dissipated by a reference to his own works. Even in the brief introduction to his own fragments of natural orders, he has placed it in so clear and perspicuous a light that it is impossible to mistake it. ' Natural orders,' says he, 'cannot constitute a method 
without a key. In distinguishing plants, the artificial method is alone of any avail; a natural method being scarcely, or not at all, possible. Natural orders are useful in acquainting us with the nature of plants, but an artificial method is requisite to their discrimination.' And to this he has added, in language that must for ever remove all ambiguity on this head, "Those persons who, instead of a natural method, have arranged plants in fragments of such a method, and reject an artificial one, seem to me to resemble those who having a convenient and well-roofed house, overturn it in order to build one in the place of it, of which they are unable to finish the roof."

${ }^{6}$ That Linnæus has in many parts of his works highly commended those who have distinguished themselves in investigating the natural relations of plants, is certain; but to suppose that by this he meant to approve of those who pretended to have formed a natural arrangement, is to attribute to him an opinion which he has disavowed in the most pointed terms. 'A real botanist,' says he, 'will investigate the natural order of plants when it can be discovered. But he will not boast of having discovered a system perfectly conformable to the laws of nature.' And among his diagnostics of pretended botanists, he particularly includes 
that of 'presuming that they are acquainted with a natural method.' "**

Now, after all the boasting and misrepresentation that have been made concerning this socalled natural system, can any man tell what the natural system is? Every country seems to have one of its own, and it is so very pliable that every writer models it according to his own fancy. Of these modifications, Dr. Lindley in his Vegetable Kingdom, has given a view from the time of Ray, in 1703, and of Linnæus's Fragmenta in 1751, down to the present period, and a few glances at his statements will show the uncertainty and fluctuation which prevail throughout.

1789. Jussieu's system appeared, founded on the principles of Ray and Tournefort.

1810. Robert Brown's Prodromus Floræ Novæ Hollandix, \&c.

"In this work the system of Jussieu is principally followed, but the classes are omitted, and the sequence of the orders is changed."

1813. De Candolle, Théorie Elémentaire de la Botanique, \&c.

Dr. Lindley adopts the series of classification laid down by De Candolle, because he thinks it "that which is least removed from a natural sequence, and partly because it is

* Wm. Roscoe, Linnæan Transactions, vol. xi. p. 6. D 3 
convenient and easy for study. But let no one imagine (he says) that $\mathbb{I}$ attach the least importance to it."

In 1819, in a second edition of his Théorie, De Candolle proposed certain groups under the name of cohorts, but in another edition published since his death, by his son in 1844, "these cohorts are all broken up, and considerable alterations are made in the sequence of the natural orders." 1825. Agardh - Classes Plantarum.

"The principle of disregarding characters, and trusting merely to (presumed) affinity, is carried to such a length as to diminish the value of the groups."

1827. Dumortier — Florula Belgica.

This author "does not appear to have given any account of its principles."

1830. Bartling — Ordines Naturales Plantarum, \&c.

"In this work the vegetable kingdom is divided into eight principal divisions or alliances, called by the author classes. The latter are furnished with detailed characters drawn up in the same manner as those of the orders, and to the whole is prefixed an abridgment of the plan of classification. The synonyms of the alliances are slightly given ; but it is remarkable that they do not contain any allusion to the anterior works of Perleb and Agardh."

1832. Hess J. Uebersicht der Phanerogamischen, \&c. " essentially an imitation of the method of 
De Candolle, with some changes in the sequence of orders."

1832. Schultz Carl. Heinrich. Natürliches System, \&c.

"In some respects this is like the system of De Candolle. The author first breaks up the vegetable kingdom into Homorgana, which have an exclusively cellular construction, and Heterorgana, which are formed with spiral vessels, and laticiferous vessels in addition. These are evidently the cellular and vascular plants of De Candolle."

1833. John Lindley. - Nixus Plantarum.

"This was an attempt, in imitation of Agardh and Bartling, to reduce the natural orders into groups subordinate to the higher divisions. The author threw aside the distinctions between perigynous and hypogynous insertion as uncertain, and leading to bad' grouping, insisted upon the value of albumen as a primary character, and objected to the general principle that the sections of plants are to furnish their character, and not a character the section. Finally, he maintained that no sections are capable of being positively defined, except such as depend upon physiological peculiarities; and that all other collections of species, by whatever name they are known, whose distinguishing marks are dependant upon structure alone, merely exhibit tendencies to resem. 
blance in certain points, for which tendeneies definitions are impracticable."

1834. Paul Horaninow, Primæ Lineæ Systematis Naturæ, \&c.

"Here the Vegetable Kingdom is divided into four circles:" - "each of these is broken up into classes." - "By this author, as by some of the German naturalists, Fungals and Algals are expelled from the Vegetable Kingdom, and form a part of a kingdom of Phytozoa."

1835. Elias Fries, Corpus Florarum provincialium Suecix.

"In this work, the author has given a general scheme of arrangement according to his own peculiar views, and has applied it to: the Flora of Scania."

1835. Martius, C., Conspectus Regni Vegetabilis, \&c.

"The motto prefixed to this treatise, "Ye shall know them by their fruit,' explains the principles upon which Dr. Von Martius has constructed his system. He assumes 'that because the fruit and its seed, or the parts analogous to them, constitute the crown and end of the whole nature and vitality of plants, on that very account it must be superior to the other parts in dignity." - " Accordingly its variations are scrutinised with much care, and many new terms are proposed for the sake of expressing those variations with great precision:" 
1836. Sir E. French Bromhead, Bart. In the Edinburgh Journal, April 1836, and Magazine of Natural History for 1840. How very simple and self-evident are the principles on which the Baronet has constructed his system, may be gathered from this observation of Dr. Lindley. "He (the Baronet) considers the theory of the circulation of organic forms to be confirmed by his method, but does not look on them as closed, or re-entering circles. He would rather compare them to the approach of the returning parts of a spiral, or to the similarity of the opposite ends of a fusiform figure." This, I presume, is some of the nonsense which owns M'Leay's Horæ Entomologicæ as its original parent.

1836-1840. Stephen Endlicher, Genera Plantarum secundum ordines naturales disposita.

"Upon this system has been published the most important systematical work that has appeared since the Genera Plantarum of Jussieu in 1789." "It has been executed with great skill, but it is too much dependent on mere theoretical considerations, and is difficult to use, in consequence of the looseness of the characters assigned to what the author names classes, which are equivalent to my (Dr. Lindley's) alliances."

1838. John Lindley, Article Exogens in the Penny Cyclopedia.

"In this place the author's views, as ex. 
plained in previous works, were considerably modified, so far as regards Exogens. He proposed, in the first place, to abandon altogether the old divisions of polypetalous, monopetalous, and apetalous plants, and to reconstruct the whole fabric of exogenous classification upon the following principles," \&c. "And thus the three monopetalous, apetalous, and polypetalous divisions were exchanged for five others founded upon totally different principles. It will be seen that this scheme has been partly adopted in the present volume."

1838. C. J. Perler, Clavis Classium ordinum et familiarum, atque index generum regni vegetabilis.

"The alliances are often well constructed, but, not having the genera arranged under them, they are extremely troublesome to use."

1839. John Lindley, Botanical Register, p. 77. "On this occasion the author directed his attention to an extension of the primary classes of plants, which he proposed to raise to eight."

1839. Thomas Baskerville. Affinities of plants.

"In the main, he adopted the scheme of orders in the Nixus Plantarum; but he criticised that arrangement with some skill, and avoided many of its worst errors." This, at all events, is candid.

1841. Trautvetter Ernst. Christian, De novo Systemate Botanico. 
"This is a speculative disquisition upon the philosophical way of classing plants. The author begs that he may be understood to have executed his task, not like a botanist, but like a philosopher."

1843. Adolphe Brongniart, Enumération des Genres de Plantes, \&c.

"The apetalous division of Jussieu is abandoned on the ground that the orders belonging to it are an imperfect state of polypetalous orders (called, after Endlicher, dialypetalous). The impracticability of a lineal natural arrangement is insisted upon. Rules are to be formed upon à posteriori, not $\grave{a}$ priori, considerations. Albumen is regarded of high value, especially the difference between farinaceous albumen and that which is fleshy, oily, and horny, which last are taken to be slight modifications of each other. Finally, the direction of the embryo is regarded of more importance in its relation to the pericarp than to the hilum." This does not command the unqualified approbation of Dr. Lindley, who states that " the great faults of this arrangement in bringing amentaceous into contact with leguminous plants, in separating cloranths from pepperworts, myrtle-blooms from hippurids, and many such instances, need not be insisted on. Such a system cannot be founded on sound principles." I should 
like much to ascertain what these sound principles are, as, unfortunately, so dull is my apprehension, that I have never yet been able to discover one of them.

1843. Paul Horaninow, Tetractys naturæ seu systema quadrimembre omnium naturalium.

"No distinctive characters are proposed for any of the groups, so that means are not afforded by the learned author of judging of the principles which have guided him in the details of his classification."

1845. John Lindley, The Vegetable Kingdom.

I have no opportunity of knowing what other systems, classifications, or floras, have seen the light since the publication of this last, except Dr. Steele's Field Book, Dublin, 1847 ; and he in his Introduction, of course, considers the Linnæan system, not exactly in the light of a "useless weed," but "as the beautiful structure of a past age, but which is altogether unsuited to the requirements of a more enlightened generation." As no two writers, however, in this enlightened generation ever agree in their natural arrangements of plants, though each very generously endeavours to illuminate with his own inward light all the rest of the world, it would be unfair to expect that the author of the Field Book should humbly follow, pari passu, in the steps of his predecessors; and accordingly we find him stating (Introd. p. v.) 
"that, with reference to the arrangement of the orders adopted, it may not be unnecessary to offer a few remarks, as it differs from those natural systems more generally known as such." He does not, however, think it necessary "to state all the reasons" by which he has been influenced in that "now brought forward." I will not attempt stating the principles by which he has been guided in his arrangement: I suppose they are as good as those of any other of the same school: but to do so would take up more time than I wish to spare, and a better reason still is, that I do not understand them any better than I can Dr. Lindley's lucid explanation of his Nixus Plantarum.

From these notices, it must, I think, be pretty evident that what is called the natural system of botany is one chaotic mass of confusion and uncertainty. Every writer on the subject fabricates a system to his own liking, and among them no two are alike. But it will be said that a large number of labourers in the field will in time make all plain, and the true natural system be at length fairly discovered. But is there such a thing in nature herself as a natural system of vegetables? There are now, it is said, nearly one hundred thousand different species of plants known; but when we consider the immense regions of the earth's surface that have never been seen nor investigated by the eye of the naturalist, that 
every country newly visited presents plants never previously known, and that even in those which have been the most thoroughly scrutinized - England, for example, - even to this day new species occasionally come to light, we may not unreasonably conclude that, perhaps, not two thirds of the vegetable kingdom have as yet been discovered; and if this be the case, when is the system to be completed, when every discovery of a few new genera may disconcert the whole fabric? How superior to this is the system of Linnæus, in which, were a million of plants never before seen or heard of, to be discovered, each would at once take its place in its regular class and order.

I must now advert to a little finesse held out on every occasion to the disparagement of Linnæan botany. We are told that it leads the student only to the names of plants. According to Richard some imagine "botany to consist merely of a knowledge of the names of plants," and that, "although they may have learned a great number of names, they have no real knowledge of the plants, and are unable to distinguish them from each other. They are like persons who, in learning a language, get by heart a great number of words without knowing their meaning." * This is one

* Elements of Botany and Vegetable Physiology, by A. Richard, translated by Wm. Macgillivray, preface to lst ed. p. xxiii. 
of the many groundless statements brought forward in the face of truth and common sense against Linnæan botany. Did any person, in learning a language, ever get by heart a great number of words without knowing their meaning? Did any one ever study plants by the Linnæan system, and yet have no real knowledge of them, and not know one from another? Why it is one great excellence of that system that it does teach us to distinguish plants from each other; and it is the only one that has ever effectually accomplished that object. Yet this is the reiterated calumny going from mouth to mouth, and from volume to volume, which, with others having as little regard for truth, are bandied about by the contrivers of what are called natural systems.

I will agree so far, however, with these writers, that the mere knowing of a name is of little or no value. If I hear of a place on the globe called Ireland, if I know nothing of its geographical position, of its scenery, its zoology, its botany, its history, or its inhabitants, then I know it by name only, whatever that may be, Hibernia, Ireland, or the Emerald Isle, and this is knowing it by its name or names, but nothing more. But it I read of it under any of its appellations, though I had never heard of any of them before, and wish to learn something farther respecting it, I would 
have recourse to a gazetteer, a geography, a maps, and a history of the country, and so learn whatever is known relating to it, though, had I never heard a name for the island, I could have no key for learning any thing concerning it: so that even the name alone will sometimes open up the path to gain knowledge, though in the name itself there is abstractedly nothing. And this is the case with botany; the insulated name is nothing, and so it is even in things where we can get little farther than the name. If I learn that there is such a constellation as the Ursa major, the Pleiades, Orion, Cassiopea's chair, \&c., I know nothing farther than that such things are; but if I extend my research beyond this, study a map of the stars, and then be able to point out on the heaven itself what is one constellation and what is another, even that is something more than the mere name of the thing.

Let me now suppose that two persons, $A$. and $B$, are walking in a wooded country. $A$. observes that he never saw finer beeches, ashes, birches, alders, \&xc., and $B$. replies that the trees around them are indeed very fine, and their names have long been quite familiar to him, but at the same time he cannot tell one tree from another; here, then, $B$. knows the names of the trees, but cannot tell what any one is, though standing before his eyes, and this is the only extent to which these writers would fain impress upon us, that Linnaan botany 
can lead. A., however, is acquainted not with the name only, but with the tree itself. On examining it, he knows what the object of his investigation is, and, being acquainted with the principles of the Linnæan system, he refers it to its class and order, compares its different parts with the description given in a Flora, finds from the latter its different synonyms; and hence the various works into which he may look for a full description of every thing known concerning it. But suppose that he had previously known nothing whatever of the tree, though it were the first time he had ever seen it, yet, should it be in the flowering state, he can, by the same process, ascertain what it is, and gain a knowledge of its entire history; but it is absolutely as false as it is absurd, to assert that Linnæan botany leads only to a knowledge of names. To ascertain a plant when seen, and learn its scientific appellation, is the very first and the most important step to all botanical knowledge, and, in leading to this, the system of Linnæus leaves every other at an immeasurable distance.

Neither does it inculcate the erroneous doctrine, that the plants contained in its classes or orders are in each characterised by similar properties and virtues, - a position on which the makers of natural systems rest in a great measure the superiority of their fabrics. There is not, perhaps, a single 
species on the face of the globe that has not something peculiar to itself, and no trust should ever be implicitly put in general resemblances, or apparent affnities between plants, no matter what classification they may be arranged under. Exceptions will always be found to their general properties, no matter how natural their assemblages may seem to be; and thus, even among the grasses, which without any theory may be considered a really natural family, there are some species, which, instead of possessing the bland and nutritive properties of the great mass of the tribe, are decidedly poisonous. In our own country the Darnel (Lolium temulentum) is generally known on account of its deleterious properties. In the north of Ireland, it is vulgarly known by the name of Sturdy; and when it grows in any considerable quantity among oats or barley, the meal produced from these becomes unmarketable, as soon as the spurious mixture becomes known. The effects it produces are giddiness, sickness, great general debility, and an irresistible tendency to sleep, such as would be caused by a strong opiate, or other powerful narcotic. Linnæus states that, when malted with barley, the ale soon intoxicates, and it is well known that it has this effect when used in the distillation of spirits. It is said, indeed, that near London it is grown in large quantities, probably with the nefarious object 
of adding to the intoxicating quality of distilled or fermented liquors. Used in a large proportion. in bread it may even prove fatal, as in the case of a farmer near Poitiers in France; but a more melancholy example of this is given by Mr. Ainsworth, in the tenth volume of the London Geographical Journal, p. 512. "A melancholy scene," he says, "presented itself on our arrival at Antioch in the actual decimation of the troops then quartered there; 700 men were in the hospitals, one of which is Ibrahim Pasha's late palace (which he is said to have sold to Mohammed Ali), and the average mortality was from fifteen to twenty per day. Upon inquiry of the medical officers, they attributed it to the common fever of the country; but upon visiting the hospitals I found the symptoms and course of the disease to present quite a different face. The attacks were sudden, accompanied by giddiness and great prostration of strength: this was soon followed by a comatose state; the tongue was paralysed and the pupil fixed; and if powerful remedies were not early administered, the attacks proved fatal in from four to eight or twelve hours. The attention of the medical officers being roused to the true nature of the malady, inquiries were immediately instituted most minutely into the food and drink of these poor men; nor was it long before the corn was ascertained to be largely 
adulterated with the seed of the Lolium temulentum, well known in the East, and even noticed in Scripture, for its very fatal effects. Ibrahim Pasha sent orders to have the afflicted regiment removed to Aleppo to recover its strength." * Graham, also, in his catalogue of the plants of Bombay, p. 234., says of the Paspalum scrobiculatum, which is a common and cheap grain, but not wholesome, that there is a variety called Hareek which has the same narcotic qualities as the Lolium temulentum. Humboldt also mentions a grass (the Sesleria quitensis of Sprengel's Species Plantarum) found in Peru, which is highly poisonous and fatal to animals, and Loudon's Cyclopedia of Plants states, that the Bromus mollis is said to cause giddiness in man and quadrupeds, and to be fatal to poultry.

Setting aside, however, the deleterious quality of the grasses mentioned, we may advert to other properties which are innocuous. Their nutritive characters are found to depend upon the quantity of various matters entering into their composition, viz., sugar, mucilage, albumen, bitter extractive, and salts; and we find a most competent authority stating, that "not two species of grasses are found to agree in the proportions of these vege-

* Mr. Ainsworth's Journey from Constantinople to Mosul, in $1839-40$. 
table principles contained in each; as instances, the Elymus arenarius affords the largest proportion of sugar, the Poa compressa (var. erecta) consists almost of pure mucilage, and the Festuca pennata, or Holcus avenaceus, \&c., a greater proportion of bitter extractive and saline matters." * We may thus see that even in this, perhaps the most natural family of plants, and where we might least expect to meet with discrepancies, no two genera, no two species, have properties exactly alike, and the same remark will apply to every thing respecting them. Every species has a history of its own, no matter how close a resemblance it may bear to the general family. When we observe the cattle grazing in our pastures, we would be inclined to suppose that in all parts of the world their feeding on grasses would be equally salutary and safe; but we would be mistaken, and of this I will mention a few instances. Nothing can be more beautiful or rich than the meadows and pasturages of these kingdoms; and yet, even here, we sometimes find that what may be called the mechanical structure of some grasses proves highly injurious to the animals feeding on them. Thus the awns of the Hordeum murinum, mouse barley, or way-bennet, which is not common

* George Sinclair, Loudon's Gardener's Magazine, vol. i. p. 28. 
in meadows, though in many places frequent by road-sides, and at the foot of old walls, when it does get intermixed with the hay, is very injurious to horses, by sticking in their mouths, and rendering them so sore that they are unable to eat.* The Hordeum maritimum, in some parts of the isle of Thanet, where it is called squirrel-tail grass, is so pernicious "as to be absolutely impracticable to horses unaccustomed to it, frequently occasioning inflammations." $\downarrow$ Another British grass, and one of the most beautiful of its tribe, the Stipa pennata, or feather-grass, though fortunately very rare now, if not extinct, is, where it is plentiful, extremely injurious to sheep. In the first volume of Loudon's Gardener's Magazine, p.442., reference is made to a pamphlet published by two professors in the university of Hungary, entitled "De Stipæ Noxa," from which it appears that the species mentioned, and another (not British), the Stipa capitata, are very common in certain pastures in Hungary; that the feathered seeds carried by the wind, fall upon the backs of sheep, and by their hygrometrical action, work their way mechanically through the wool, then get through the flesh, and finally enter the body, piercing the intestines or liver, and causing the death of the animal.

* Curtis on Grasses, p. 31.

† Withering's Arrangement, \&c., vol. ii. p. 204. 
From Pallas, again, we learn that in the southeastern mountains of the Crimea, various grasses, as the Aigilops caudata and ovata, Elymus caput medusce, and others, are most injurious to horses, \&c. He states that from the roughness of their bearded parts, they are all very injurious to cattle, horses especially, as by adhering to their mouth and throat they often prove fatal. I will next observe, that if all plants of the same natural family possessed similar qualities, we should never be afraid, in any part of the world, to wend our way through tracts of country clothed with a grassy verelure. Suppose, for instance, that instead of taking a ramble among the green meadows of England, or the verdure of the emerald isle, we should direct our steps throngh some of the verdant tracts of southern Africa, we might find ourselves in a different sort of vegetation, though of grass all the while, from the soft carpet of brome-grass, the meadow soft grass, and others of our home pastures. Instead of these, we might find, to our cost, that instead of these gentle beautifiers of the surface of old earth, we had got involved among the spiny poa-Poa spinosa - whose families of flowers, according to Burchell, form a bunch of thorns so strong, sharp, rigid, and pungent, that no animal could graze near it, nor the nakedlegged Hottentots venture to walk among it, E 4 
though it is not more than a foot and a half high. * It will readily be said that such annoyance could be easily guarded against. A good pair of boots would set the grass at defiance, and perhaps they would; but let us go to another portion of the globe, and we may not find a remedy so easy. In the island of Socotra, there is found a grass of a still more formidable character than the Poa spinosa. It is about twenty inches high; at its upper part radii branch forth, and at the end of each of these is a sharp barbed spine. Lieutenant Wilstead of the East India Company's marine service, says, "Whenever we dismounted from our camels to walk, we found these a great pest and annoyance; for they adhered in great numbers to our clothes, and frequently penetrated the flesh. Considerable care was also necessary in extracting them; for if they were broken, and the barbed parts left in the wound, a painful swelling arose, and they were not removed until suppuration took place, and they became, by that means, ejected. They also adhered with much tenacity to our clothes, from which, when once lodged, it was difficult to re. move them." $\uparrow$

We may thus see, without going farther, that even in this most natural family of plants, the

* Burchell's Travels, vol. i. p. 211.

$\dagger$ London Geog. Journal, vol. v. p. 136. This grass belongs to the genus Pennisetum. 
greatest differences are to be found in their properties, whether poisonous, nutritive, or mechanical; and indeed we may lay it down as a certain fact, that whenever a class or order of plants, no matter to what system they may belong, whether founded on the system of Linnæus or Jussieu, contains a number of genera, there will be found anything but uniformity in their properties; and the same may be said to take place also to a considerable degree with regard to genera; - that is, if a genus include a great many species, there will be found among these, wide differences in almost every respect, independent of their mere botanical characters, and this may even occur when the species are small in number; thus, of the four species of Lolium described in Loudon's Cyclopædia of plants, three are innucuous, and one, the Lolium temulentum, fatally poisonous.

It would be tiresome to me, as well as to my reader, were $I$ to analyse fully the discordances to be found in the plants belonging to the orders of any one writer from Jussieu downwards; but, as Dr. Lindley has sounded the praises of the natural system to such an extravagant pitch, I will point out from his own book, "The Vegetable Kingdom," some of the contradictory qualities of the plants contained in his natural orders; but which his repeated assertions would have us to believe cannot be any thing but similar to each other. I 
have already given a sample of this in the case of Peruvian bark; but through the whole system the same contradictions and inconsistencies prevail.

I will first advert to the order Liliacex, in which the Phormium tenax, the Sanseviera, \&c., afford a strong cordage, even superior to hemp, but no article of food; while some, as the onion, garlic, and leek are eatable; but we could not manufacture from any of them even a sewingthread. The bulbs of squill, and various others, are nauseous and emetic; but, on the contrary, the produce of the aloe tribe is extensively used as a purgative; and here we have an example of plants of the same genus having different properties; for we are told that the drug is obtained only from the arborescent species; and hence those that are not tree-like do not produce the drug at all. While the squill is emetic, and the aloe purgative, the Gloriosa superba and Crown imperial are virulent poisons. Then again, in other plants included in this order, we find them producing resinous secretions, as the Gum Dragon from the Dracæna Draco; and the Botany Bay gum, which is fragrant, and "flows in abundance from the Xanthorrha arborea," and certainly must be very unlike the juice of leeks, onions, or garlic, while, instead of the strong and disagreeable odour of the latter, we have in the same order the 
tuberose emitting its "delicious fragrance," as also the sweet emanations of the hyacinth.

On the order Euphorbiacex I need not dwell, as the author himself has said all that is necessary for showing how the plants contained in it agree with each other. "In fact," he says, "there is a gradual and insensible transition in this order from mere stimulants to the most dangerous poisons."

Order Juglandaceæ, page 292. This order contains only four genera, but still we find the same disagreements: thus the seed of the walnut "is esteemed for its sweet and wholesome qua. lities;" "but, the seeds of Carya amara are too bitter to be eaten."

Order Menispermaceæ, page 307. "Active narcotic and bitter qualities prevail among the species; the former in excess, rendering them poisonous; the latter causing them to be regarded as valuable tonics. A few are mucilaginous." This, in plain language, is simply saying that some are poisonous, some tonic, and some neither the one nor the other.

Order Cucurbitaceæ, page 311. "Although we best know the cucurbits by their use as eatable fruits, the melon, cucumber, vegetable marrow, and similar plants being the common species, yet acrimony and a drastic tendency pervade many species, the fruits of some of which afford 
cathartics of remarkable power, acting, in even small doses, with great energy on nearly the whole line of the alimentary canal." The fruit of some species of Luffa "is violently cathartic." Yet that of Luffa acutangula is " a favourite pot-herb of the natives of India, and is esteemed very wholesome." The drug called Elaterium has, from the most ancient times, been known as a most violent drastic; it is the inspissated juice of the Momordica elaterium, and is so extremely powerful, that in its use not more than one sixth or one fourth of a grain can be safely ventured on; but Dr. Lindley states, that while "'all the numerous cultivated varieties of the melon and cucumber are known to be wholesome, some, if not all, the Indian species of Momordica seem equally safe." The seeds, again, of Telfairia pedata, an African plant belonging to this order, "are as large as chestnuts, and said to be as excellent as almonds, having a very agreeable flavour." But then, with the usual contradiction, we are told that the " oily seeds of Feuillæa cordifolia, a West Indian shrub, are intensely bitter, and act violently both as emetics and purgatives."

How, with such examples before them, men will continue to persist in maintaining the idea that if we know the properties of any one plant included in these so-called natural orders, we can fairly calculate on similar properties being pos- 
sessed by the others, is to me very unaccountable; and still more so, that even medical men of high and most deserved reputation can lend their voice in supporting the delusion; but so it is, and hence Dr. A. Todd Thomson, in his Elements of Materia Medica, says, that "although the Linnæan or artificial system be that which has hitherto been employed for classing medicinal plants as objects of botany, yet the natural system holds out so many advantages to medical science, that there can be one opinion only of its superiority in a practical point of view. It informs the medical inquirer not only of the botanical affinities of the plants, but also supplies him with a knowledge of their properties and qualities. This acquaintance with the properties of even one plant of any order, enables him to form some idea of the remedial value of all the other plants in the same order, and, if needful, to substitute, upon fixed principles, any one of them for that which is more usually employed." *

The only possible way in which I can attempt to account for such a passage as this, is, that the writer adopted his opinion from hearsay, without examination of the subject, and indeed the confident assertions with regard to the superiority of the natural system and its advantages, though

* Second edition, page 68. 
"false as dicers' caths," have been so frequently repeated, that, joined with unmeasured abuse of the Linnæan system, the statements have been received on trust; and yet it is incomprehensible how the fabricators of these systems could so deceive themselves, and not less so, how far they have deceived others. It would be tedious, and I trust unnecessary, to advert farther to the orders of the "Vegetable Kingdom," and it may suffice to say that the same contradictions characterise the book almost from first to last, and that every thing respecting the unanimity of plants in the different orders is as unstable, uncertain, and unsatisfactory, as is the account of their medical virtues: Dr. Lindley may tell us about the "hidden characters with which nature has labelled all the hosts of species that spring from her teeming bosom;" but were they labelled, they would not be hidden; and although we should search for the key to explain the meaning which "lies enveloped in the folds of the natural system, and is to be found in no other place," I believe we might, with about an equal chance of success, try to find a key for the fold that envelopes the philosopher's stone, the wishing-cap of Fortunatus, or the lamp of Aladin.

What must be the impression made on the mind of the medical student, when he reads the above observations of Dr. Thomson in his 
Materia Medica, or hears such doctrines promulgrated in the lectures of that gentleman in the London University, but that the natural system is all in all, and the Linnæan useless and deservedly exploded? To such students, however, this would be of no great moment, unless, that thinking the door was thus thrown open to the acquirement of much substantial knowledge, they were to devote that time to it which should be employed in studies more useful and essential to the future practice of their profession. I have already adverted to botany, as a branch of medical education, and I will now enlarge a very little farther on the subject; and I again repeat, that every practitioner, whether as physician or surgeon, ought, eren in justice to his own character, to have, to a certain extent, a knowledge of that science; but that it is essential to his utility in the treatment of his patients, to possess more than a moderate knowledge of it, I am not prepared to admit. Mr. Gray, in his "Natural Arrangement of British Plants, according to their Relations to each other, as pointed out by Jussieu, De Candolle, Brown, \&c.," which was published in 1821, that is, nine years prior to the publication of Dr. Lindley's Introduction to the Natural System, though the latter gentleman has not made the slightest allusion to it, makes the following observation, which seems to embody everything necessary to the phy- 
sician, so far as medicine is concerned. "Another part of medicine," he says, "in which the use of botany is evident, too frequently happens in consequence of the similitude of plants to one another, so that those ignorant of the means of distinguishing them are led to use a plant of such powerful action on the human frame as to kill, or very violently affect, the unfortunate person who has mistaken it for some nutrimental vegetable, especially foreigners, who use a greater variety of vegetables than ourselves. Yet, even among us, the instances are not rare, in which hemlock has been mistaken for parsley, the roots of wild cicely for parsneps, $\operatorname{dog}^{\prime}$ 's mercury for a spinage herb, the berries of night-shade for esculent ones, and more especially, the deleterious mushrooms for those that are eatable with some degree of safety; for in truth all are to be held as of doubtful salubrity. Now the skilful botanist, who can determine, from the remains of what has been taken, the cause of the symptoms, has an evident advantage in respect to the mode of treating his patient over one who is ignorant of the cause, and must therefore prescribe at random."

This is modest enough, but does not come up to the ideas of some of the supporters of Jussieu, who carry their commendation of botany to a rather extravagant length. Thus Richard says, "It is an inexhaustible source of efficacious remedies 
to the physician who is possessed of the knowledge requisite for enabling him to avail himself of its treasures. No class of natural bodies affords so many useful medicaments. Now, what medical man, anxious to exercise his art in a manner worthy of its importance, can, without some misgivings, prescribe to his patients plants which he scarcely knows by name, which he has never seen in the recent state, and which he cannot distinguish even from those to which they have no affinity, because he has not studied their characters? He is like the surgeon who, in performing an operation, is all the while ignorant of the organs which his instrument is dividing. The physician, in this case, not only shows himself to be unworthy of the high opinion which may have been conceived of him, but, by his culpable inexperience, renders himself liable to approve of errors the most prejudicial, and to sanction mistakes the most fatal to suffering humanity." *

Now I can readily imagine that in some rare instances a practitioner in the country might make use of a few plants in the recent state, and if the apothecary or physician wished to employ a hemlock poultice or fomentation, it certainly would be

* Elements of Botany and Vegetable Physiology, including the Characters of the Natural Families of Plants, by A. Richard, M.D. Translated by W. Macgillivray, A.M. Preface to the 1st edition. 
quite necessary that he should know exactly the plant to be employed; but this is a thing that can but very seldom occur, and indeed, in these islands at least, the number of plants had recourse to by the regular practitioner in the recent state is very limited, and they require very little, if any scientific knowledge to be acquainted with them. He need not study Jussieu or De Candolle, to know the bog-bean, or digitalis, or henbane, or chamomile, or broom, or dulcamara. In large towns, I believe the physician seldom, if ever, thinks of employing recent plants; and as for his having a botanical knowledge of those included in the Materia Medica, it is at all events not absolutely necessary. It is creditable, I will grant, to a medical man to be acquainted with the botany of the vegetable drugs he may prescribe; but in general it is by no means requisite, and can neither tend to raise his reputation, nor the want of it to diminish his value. Must a physician, when he prescribes rhubarb, or ipecacuanha, or jalap, or cascarilla, or columba, \&c., know the classification or botanical characters of the plants producing these articles? Certainly not; the knowledge he requires is, not to know the botany of the article, but whether it is a sound and good article of the materia medica. He requires to be acquainted with its qualities as a drug, and to know its proper application in treating disease, 
the mode of prescribing it, \&c. If he write a receipe for pills composed of extract of hemlock, or hyoscyamus, he will know whether the extract is genuine, and all the botanical knowledge he could possess of the plants in their growing state would not make him one grain the wiser; in fact, we might just as well say that the cook in the kitchen could not be sufficiently acquainted with the qualities and application of ginger, nutmeg, allspice, and pepper, unless she knew their botanical history, as that a medical man requires such science for understanding nine-tenths or more of the vegetable drugs which he has occasion to prescribe. We use our tea, coffee, and cocoa, without caring anything for their botany; and a man can smoke and snuff tobacco with perfect ease and satisfaction without even knowing the country where it grows, much less its botanical classification.

Were it true, however, that the genera and species belonging to the different families or classes called natural have similar properties in each, I would admit at once that this would be a matter of the very highest consequence; but I cannot see even the slightest shadow of proof for drawing such a conclusion, and of this I have already given sufficient evidence: anything like certainty is not in its nature.

Dr. Lindley may tell us that every plant "bears inscribed upon it the uses to which it may be 
applied, the dangers to be apprehended from it, or the virtues with which it has been endowed," and that the language in which all this is written is in the "hieroglyphics of the Almighty," but that the skill of man is permitted to interpret them. But if we may judge from the past, I fear this skill will be a long time in coming. The disciples of Jussieu, indeed, however prolific they may be in fancies, seem to have made a very slow progress in elucidating the hieroglyphics alluded to, though they have added no trifling number of their own to the list: - but give us patience, all will be unriddled in time; for, says Dr. Lindley, "the Natural System of Botany may be likened to the plan of a vast edifice, at the construction of which many are labouring. Certain courts and quadrangles are easily set out; a particular style of architecture is agreed upon, and it may be even settled irrevocably in what places the state apartments and cellars are to be stationed; but when farther details are to be discussed, many unsatisfactory attempts must be made by the architects, and many an awkward arrangement of the rooms proposed, before a final plan can be produced. If perfection in such small matters is impracticable, if it is impossible to arrange all the details of even an edifice, so as to satisfy all critics, how much more hopeless must be the task of classifying the infinite works of the creation! To demand perfec- 
tion in a work of that nature is little less than impious; for perfection is the attribute, not of man, but of his Maker."

Surely the builders of Babel must have been expert and good workmen, and greatly superior, in forming their plans, to the bungling architects of the above "vast edifice." They had agreed upon the state rooms and cellars, but their thick heads did nothing but squabble about all the rest of the house; the bed-rooms, the pantries, kitchen, scullery, wash-house, stables too I suppose, could only be at last fixed upon after "many an awkward arrangement;" but there could not, I believe, be a better illustration of the proceedings and plannings of the builders of natural systems, with this difference, however, that they will never, to the end of time, agree upon a "final plan."

After all that has been written on the natural system, - after so many books having stated that the plants described in them are arranged according to the natural system, and every follower of the Jussieuan method speaking invariably. of the natural method, yet strange to say this is all a matter of moonshine; and Dr. Lindley himself, who published the first edition of his "Vegetable Kingdom" under the title of an Introduction to the Natural System of Botany, and who triumphantly exults in having completely beaten the Linnæan system out of the field, tells us that it is 
a vain idea to think that we can explain the system of nature. "An arrangement," he observes, "which shall be so absolutely correct an expression of the plan of nature as to justify its being called THE Natural System, is a chimera. All that the naturalist can do is to carry into effect the principles above explained" (namely; those that the author has previously laid down) "with a greater or less amount of skill; the result will be A Natural System."* The above principles! why, every fabricator of these systems forms what he calls principles of his own, and on these founds his scheme, and gives it the title of the natural system; and hence no two of these systems rest upon principles of the same description, and as the real system of nature, if there be such a thing at all, cannot be ascertained, then the only meaning we can in truth attach to the title is, that each of these systems is the system of the writer, but must certainly be a misnomer, if called the system of nature; it may be Jussieu's system, De Candolle's system, or that of twenty others, but the system of nature it is not.

Another thing to which I must make some reference is the assertion that every country, every region, produces plants capable of curing or remedying all the diseases of man peculiar to it; and

* Vegetable Kingdom. 
a very pretty theory it is, except that it is not true. We might as well be told that in every country fruits would be found fit for food, yet in the whole immense continent of New Holland, there are only two plants of this description, one resembling our common bramble, and the other (Leptomeria Billardieri), which bears only a small berry: and alas! for Greenland, whose only natural vegetation consists of stunted brushwood and grass; Iceland, in which the only grain that can be raised is barley, and the native plant which consist of little more than coarse grass, mosses, and lichens. And how numerous are the other regions which might be mentioned, in which the inhabitants, instead of having plants for medicine, cannot even find them for food; and as to the former, perhaps they are better without them. I believe that among ourselves we have too many drugs, and that every sensible physician whose mind has been matured by observation, prescribes a very small number of such taken from the vegetable kingdom. But human credulity has an open ear and an insatiable appetite for remedies of all kinds, and quackery of every description; and to read of the virtues of plants in the old herbals and works on materia medica, from Dioscorides downwards. not forgetting the natural systems of the present time, the great wonder is, that people should die at all. Dr. Lindley states, 
and reiterates the statement, that physicians or surgeons on foreign service who understand the natural system, can, on distinct principles, understand " the qualities of the medicinal plants which nature has provided in every region for the alleviation of the maladies peculiar to it." This comfortable theory has long ago, however, been more fully developed by my countryman K'eogh, in his Botanologia Universalis Hibernica, published in 1735. In the preface he remarks, that "if the real properties or true qualities of all the herbs and trees growing in this kingdom were found out, there is not a distemper or disease which the inhabitants thereof are subject to, but there might be found out a simple, I mean a single herb, tree, or shrub, growing therein, which could cure it, or at least remove it for a considerable time, without sending for exotic herbs and drugs to foreign conntries, which destroy more here than they cure, though they might be proper and useful to the natives of those countries from whence they came, as being more natural to them." Mr. K'eogh's taste was all for recent plants, and he repudiates drugs, druggists, and apothecaries; and one strong argument which he uses is, that "we did not hear of druggists or apothecaries before the flood, (the Antediluvians were unacquainted with them, nor yet after the flood for a very considerable time: nay, in this very kingdom, there were scarcely two 
in a province a hundred years ago, yet the people then lived to very advanced years."

He regrets that still there was not a sufficient knowledge acquired of the qualities of plants, and says, "What vast advantages and benefit would it be to mankind to find out the specific virtues or true properties of the herbs; by which means there would be a simple to cure any distemper in nature. King Solomon knew them, and he wrote their specific virtues, from the Hyssop that grew upon the wall, to the Cedar of Libanus; but the discoveries that were made by him thereon are lost, destroyed by time, and buried in the rubbish of antiquity: but I heartily wish they could be restored." Could he return to this nether world, he would now know that the lost treasure had been found by fifty Solomons, and in fifty different ways; and yet he himself had made very considerable progress in gaining a knowledge of the hidden hieroglyphics, as is evident from what he proposes to tell his readers. - "In this Treatise," he says, "I design to show you what herbs are properly Anastomatic, Leptyntic, Ryptic, Carminative, Stegnotic, Styptic, Pycknotic, Emphratic, Hypnotic, Diaphoretic, Hydrotic, Ariotic, Diuretic, Traumatic, Lithontriptic, Absorbent, \&c. : - these are internal alteratives.

"Your external alterative herbs are either Malactic, Chatastic, Ariotic, Heltic, Apocroustic, 
Pyrotic, Amytic, Metasyncritic, Cathertic, Septic, Epispastic, Escharotic, Caustic, Colletic, Emplastic, Porotic, Ecprestic, Peptic, Ryptic, Sarcotic, Epulotic, Cosmetic, \&c. I shall also show what herbs are specifically Cephalic, Neurotic, Stomatic, Pnumonic, Anacathartic, Cordial, Hepatic, Splenatic, Nephritic, Hysteric, Arthritic, Cathartic, Emetic, Ptarmic, Salivatic, Masticatory, Emmenagogic, Alexipharmic, Analeptic, Galactogenetic, Spermatogenetic, Suppurative, Alexiteric, Discussive, Bechic, Cholagogue, Flegmagogue, Optic, Antiodontalgic, Antiotalgic, Anthypochondractic, \&c."

Mr. Gray, in his very elaborate arrangement of British Plants on the Jussieuan system, adopted the plan of giving translations of the Latin specific terms into literal English; he formed also a great many new genera, and even to these he gave literal English terminations:- thus, his genus Biddulphia, formed from three confervoid plants, and named in honour of Miss Biddulph; he does not, in naming the different species say Biddulphia, but Biddulph. And observe the elegant and refined taste which this plan displays: the first species, Biddulphia pulchella, he translates pretty Biddulph, which is very well, for as the genus was meant to do honour to the lady, she could not complain of being called pretty; but the second species, Biddulphia obliquata, is called crooked Bid- 
dulph; and the third, stipitated Biddulph, as if she stood, like a mushroom, only on one leg. In the genus Griffithsia, instituted by Agardh in honour of Mrs. Griffiths, so celebrated for her investigation of the Algr, we have bearded Griffiths, many-cut Griffiths, and horse-tail Griffiths. Agardh also instituted the genus Hutchinsia, from Miss Hutchins of Bantry, a lady who made many discoveries in Irish Cryptogamic botany; and in Mr. Gray's work we have, among other species of the genus, long Hutchins, - black Hutchins, - blackish Hutchins, - pitcher Hutchins, - stiff Hutchins, and (proh pudor!) naked Hutchins. This is followed, however, by a kind of amende honorable, and we have Hutchinsia pulchella, pretty Hutchins, as much as to say that "Beauty unadorned is adorned the most." As a genus of Mr. Gray's own, we have that of Vertebrata containing one species called even-topped back-bone; only think of giving the name of back-bone to a small conferva parasitic on fuci! In Scytosiphon, we have gut-leathern pipe, and others scarcely less elegant; in Palmella, broken trembler, and worm-like trembler.The genus Gastridium of Lyngbye is beautifully called Belly-weed; and we have blunt belly-weed, - very thin belly-weed, - scarlet belly-weed. Mr. Gray also formed a genus called Mackaia, from Mr. Mackay, I suppose, of the Dublin University Botanic Garden, in which we find discordant 
Mackay, - bearded Mackay, (Mr. Mackay unshaved, I presume), - heath-like Mackay, - and stiff-pointed Mackay. The genus Variolaria of Persoon, among the Lichens, is called small-pox moss. Among the Fungi, we have the Scleroderma of Persoon, called skin litter and warty skin litter, \&c. - Bovista of Dillenius is called bullfist. - The genus Gymnopus of Persoon, among the Agarics, is translated naked-foot; and we have, among others, cracked naked-foot-spindle nakedfoot, - modest naked-foot, - brimstone naked-foot, - green naked-foot, - fat naked-foot, - stinking naked-foot. The genus Coprinus of Persoon, is called dungstool; and we have, among others, halfegg dungstool, - wig dungstool, - grey dungstool, - house dungstool. Among the mosses we have the genus Gymnostomum, anglified into plainmouth; and hence bent-beak plain-mouth, bundled plain-mouth, small-mouth plain-mouth, \&c. Diphyschium is called double-hunch. Tetraphis fourtooth. Trichostomum, hairy-mouth; and among the species we have woolly hairy-mouth, - hoary hairy-mouth, - one-sided hairy-mouth, - needlelike hairy-mouth - bundled hairy-mouth, \&c. Leucodon is white tooth, and Didymodon twintooth; and we have hairy twin-tooth, odd-sided twin-tooth, \&c. Anomodon is odd-tooth; and here we have short-hanging odd tooth, and spriggy odd-tooth, \&c. In Hookeria, a genus established by Sir J. E. Smith in honour of Sir W. J. 
Hooker, we find Hookeria lucens, shining Hooker, and were we to apply the epithet shining to the great botanist from whom the genus is named, though comparatively a weak one, still it would be appropriate; but if, instead of lucens, the trivial name had been gibbosa, then Mr. Gray, according to his plan, would have called it Humpbacked Hooker.

Among the flowering plants in the second volume, similar vulgarities do not prevail so much, though there are some choice specimens: thus, among the Grasses, Tricodia decumbens (the Festuca decumbens of Linnæus) is called down-lying threecut; and in Digitaria of Haller, we have Digitaria glabra, called bald, and Digitaria sanguinalis, bloody fingers.

Is it not deplorable that such vile names, which have not even the sanction of ancient usage, should be introduced into the beautiful science of botany? It matters little what the classical names of genera and species may be, because their meaning is limited to the plants themselves, and cannot, without distorting the ideas connected with them, be literally rendered into any vernacular tongue. Yet Mr. Gray's "Arrangement" is among the most elaborate and learned works on British plants, and had he fortunately written it in agreement with the Linnæan system, and avoided the petty ambition of forming new and unnecessary genera, and fabricating names before unheard of, it would 
have been a most valuable publication, instead of coming so unnoticed from the press, that one might suppose Dr. Lindley, from his total silence respecting it, had never heard of its existence. It is, indeed, painful to think of the immense labour that work must have cost, and yet that it was so little countenanced; for, in many respects, it is among the most valuable books we possess on the botany of these islands.

It is not a little remarkable, that while writers will inflict on the students of botany the most difficult methods by which they can arrive at any knowledge of plants, they profess that by altering terms known and adopted from time immemorial, or at least that have long been in use, they render the acquirement of knowledge more plain and easy; but in almost every attempt of the kind, injury is done to the purity and utility of nomenclature, without any benefit resulting from it to the student: and, indeed, while they tell us that Linnæan botany can lead us only to the names of plants, they seem to attach a most absurd importance to such names or changes of names as they themselves may propose, though generally without one truly sensible reason why such change should be made. This is a glaring and most injurious practice in every department of Natural History, and tends most materially to create a disgust, or at least a dislike to its study.

Dr. Lindley, in his turn, is not behind-hand in 
proposing new and altering old names, and though these are not so offensive as many of Mr. Gray's, yet they appear (to me, at least) to be conceived. throughout in a very bad taste. Why should the classical term Algæ be changed into Algals, or Fungi into Fungals, a term as bad as the modern plural Funguses? Why should the Florideæ of Agardh be altered to Ceramiaceæ, and have the new-coined name of Rosetangles applied to them; or the Jungermanniæ be called scale-mosses, a term equally applicable to the whole of the moss family? Why are Andrex called split-mosses; why the Musci of Linnæus, Jussieu, and all other authors, changed to Bryaceæ, with the English name of Urn-mosses, when each genus has an appellation of its own? Why should the order Filices of all authors be changed to Filicales, or Lichenes to Lichenales; and why should two additional syllables be added to the orders of Jussieu, and other systematists? Jussieu's term Gramina is surely as good (if not better) than Graminaceæ,--Musæ as Musaceæ-Junci as Juncaceæ, - Lilia as Liliaceæ, \&c. But while the author has added additional syllables to almost every order of plants in the systems of his predecessors, yet he professes a great dislike to names of sesquipedalian length, and observes that he confidently believes "every intelligent reader will admit that such names as Urn-mosses, Taccads, \&c., are preferable to Bry-a-ce-æ, Tac-ca-ce-x," \&c., 
(I need not enumerate the whole, they are so near akin to each other, ) "and other sesquipedalian expressions." *

I will now remark that Bryaceæ cannot be called a sesquipedalian expression, as it is not easy to call by that epithet a word consisting of only four syllables; if it be, however, then the name of our good queen must be the same, Vic-to-ri-a; and even Dorninie Sampson's favourite exclamation, pro-di-gi-ous, consists of no more. But if it be a sesquipedalian expression, it is one of the author's own making, very uncalled for, and to be adopted only on his authority to supplant the universally received term of Mus-ci, or Moss-es. Taccacex is a term of the same number of syllables; but this is the author's own doing also, for by all but himself the order has been named Tac-ce-æ.

It is a great evil in every department of natural history, that so many writers seem to persuade themselves that by altering what has been long established, they may confer a benefit on science; one genus must be split into several others, specific names are perpetually changing, so that the appellation of an animal or plant this year may be quite different the next, and again changed the year following for something else. Classifications are subjected to the same ordeal, and often without any one assignable reason urged in favour of

* Pref. to Veg. Kingdom, p. xviii, 
it; and this confusion and uncertainty are perpetually added to what is too confused and uncertain already. The fashion of forming new genera, especially, has risen to a very unfortunate height; but the temptation to do so seems to be almost as irresistible as the shake of the dice-box is to the hand of the gambler. Thus Captain Brown, in the second edition of his " Illustrations of British Conchology," very properly remarks, that "it is to be lamented that ambition should prompt naturalists to change established classification and nomenclature, as nothing tends so much to retard the progress of science." And yet what has the writer of this observation done in the same work? He has fabricated no less than fifteen what he calls new genera of shells, in the very limited field of the Conchology of the British Islands.

The author of the "Vegetable Kingdom" complains, that since the time of Linnæus, the great reformer of nomenclature, "a host of strange names, inharmonious, sesquipedalian, and barbarous, have found their way into Botany," and he is anxious to do something "towards alleviating this grievous evil;" but I fear his remedy is no better than the disease; it is to give English terminations to the different orders of his system; and this in several ways; but the plan I conceive is a most unhappy one, and I cannot see what advantage can arise to the science, or its nomenclature, 
from the introduction of the following names, and of many others similarly constructed; viz.:Burmanniads, Mayacs, Phileriads, Pariads, Morads, Juglands, Lardizabalads, Kadsurads, Pangiads, Samyds, Hydrophyls, Sauvagesiads, Vivianiads, Voychads, Theads, Rhizobols, Guttifers, Humiridiads, Francoads, Xanthoxyls, Erythroxyls, Nyctagos, Saururads, Brixads, Chailletiads, Hippocrateads, Reaumuriads, Stilbids, Ehretiads, Salvadorads, Selagids, Gilliesiads, Garryads, Helwingiads, \&c.

The old English term wort meant an herb in general, but was applied more particularly to potherbs; and in reforming ourbotanical nomenclature the author has taken advantage of and applied it to many plants where it certainly was not required, and where its application would have been better dispensed with. I can see no reason why a lily should be called a lily-wort, a birch tree, a birchwort, a willow a willow-wort, a nettle, a nettlewort, or a heath a heath-wort; yet many plants besides these have been provided with this unnecessary appendicle to their ordinary names. Some, however, have escaped, and a maple is called a maple, a water-lily is a water-lily still, a laurel is a laurel, rushes are rushes, and cranberries retain their ancient appellation; but the hazel, the horn.beam, the beech, the chestnut, and the oak, are called mast..worts. The lime tree is a linden- 
bloom, and the myrtle a myrtle-bloom; the honeysuckle is called a caprifoil, and plants of the dock tribe are buck-wheats. - This slight sketch, and it is no more, may give some idea of the most recently improved nomenclature which is to enlighten the advocates of the natural system, and teach them how to steer clear of "strange, inharmonious, sesquipedalian, erroneous, and barbarous names;" and I congratulate them warmly on the acquisition.

In the same work we find the order Labiata of Jussieu and others, changed to Lamiacex, from Lamium, the dead-nettle; but it is Englished "Labiates." This order is stated to contain 125 genera, and 2350 species; but why the term Labiatæ, which forms perhaps the most natural order which is to be found, should be abolished, and a name from one of the above numerous genera be substituted in its place, is far beyond my comprehension. Neither can I better understand why the Compositx of Linnæus and most authors, and which is also one of the most natural orders, should be altered to Asteraceæ, the genus Aster being only one out of 1005 genera, containing 9000 species, as stated in the "Vegetable Kingdom." Not less incomprehensible seems the change of Linnæus's order Papilionacex, the Leguminosæ of Jussieu and others, to Fabacex, which means the bean-tribe; but is the whin a 
bean, or the indigo plant, or the locust trees, which are of prodigious size, or the laburnum, or the tragacanth plant, and hundreds of others which are no more like a bean than they are to a cauliflower? Linnæus formed his Papilionaceæ from the form of the corolla, and Jussieu his Leguminosæ from the nature of the seed-vessel. The number of genera in the order, as estimated by the above authority, amounts to 467 , and the species to 6500 , including plants of the most opposite qualities, many being nutritious, many poisonous, with a hundred other differences; but all may in some measure be legitimately arranged, as Papilionaceæ, from the flower, or Leguminosæ, from the fruit; but to call them Fabacex, or the bean tribe, is letting the fancy take a flight rather too sublime.

In like manner the Siliquosæ of Linnæus, formed from the seed-vessel, and Jussieu's Cruciferæ, founded on the corolla, have been exchanged for Brassicacex, the cabbage tribe; but I should think few persons could easily discern much likeness between a cabbage, even in the wild state, and a wall-flower, horse-radish, the shepherd's purse, or water-cresses; nor does the insertion of the term Crucifers after that of Brassicaceæ, so far as I can see, amend the matter, though had the name Cruciferæ, given to the order by Jussieu, been so translated, its vulgarity might be con- 
sidered not worthy the notice of criticism; and this remark would similarly apply to the order in the "Vegetable Kingdom" called Apiaceæ, which literally means the parsley tribe, but is translated Umbellifers. It is the Umbellatæ of Linnæus, and Jussieu's Umbelliferæ, which, among the few classes or orders which may be called natural, has in all times been considered among the first. It is said to consist of 267 genera, and 1500 species; and from one of the very smallest of the genera, Apium, or parsley, the modern term is applied to the whole; many of them among the most deleterious plants in the vegetable world.

What appears to me as the great error in the system of Jussieu, was his taking the seed as the basis of his classification ; it formed one of sand, on which nothing durable can ever rest; and hence the perpetual tinkering, patching, taking away, adding to, or altering in some way or another his system by every one who undertakes to explain it by writing. If part be Jussieu's, the next is of the author's own concocting; but, at the same time, the single, double, or no lobe of the seeds, form the great divisions on which the fabric is to rest. It is no doubt a very curious physiological fact, that plants growing from seeds composed of one cotyledon, have a different vegetation, mode of growth, and structure, from those which grow from G 3 
two; and that hence, by inspecting a plant, we can tell pretty clearly whether it is a monocotyledon, or dicotyledon. Partly from this circumstance it has been concluded that the seed is superior in dignity or importance to other parts, it being the origin of the plant which springs from it. "We know," says Richard, "that those organs which conduce to reproduction, perform the most important part in vegetable life, and that among them the embryo, which is in a manner the common end towards which all the organs of the plant direct themselves, is that which occupies the first rank in importance. The embryo, therefore, has supplied our author (Jussieu) with his primary divisions. The stamina and the pistil occupy the second rank, and afford more constant and more valuable characters than the floral envelopes." * On this principle it has been that Dr. Von Martius adopted for his book the motto "You will know them by their fruit;" but I believe a much more sensible one would have been, had he adopted a wiser classification, "You will know them by their flowers." This importance given to the seed is putting the child in the first rank, and its parents in the second; or to use an old name for the cud-weed, the "son before the father." But while the seed produces the plant, what has pro-

* Elements of Botany and Vegetable Physiology, p. 359. 
duced the sced? why should the latter be considered of higher dignity than the stock to which it has owed its origin? Why should an acorn be considered of a more noble nature than the oak to which it owes its birth? An acorn can produce only one oak, but a single oak can bring forth thousands of acorns. On what side then does the dignity lie? If such a word can be applicable at all to such a matter, surely the old tree braving the storms of a hundred winters, is more so than the acorns annually showered from his boughs to serve as food for the beasts of the forest. According to Ray one single tobacco plant will produce 360,000 seeds. Is each of these of more importance than the parent plant? It may be said, indeed, and truly, that each would produce a plant similar; but admitting this, in what respect can it be superior to those organs of the flower which brought it into existence, and without which it never would have existed at all? This question, however, about the comparative importance of different parts is idle; and in forming a classification of plants, the great and paramount question is, what plan is most manageable, easy, and certain, by which to gain a knowledge of the plants we may examine; and it is admitted by all, even its worst enemies, that in this the Linnæan is pre-eminent.

That there are groups or tribes of vegetables approaching each other so closely in the general G 4 
aspect of the species belonging to them, as to be considered not improperly as natural, there can be no doubt, and such have been acknowledged at all times; as the grasses, the palms, the pine tribe, roses, heaths, narcissusses, pinks, ferns, mosses, peonies, irises, \&c.; but these are all founded on their outward characters, their form of growth, the appearance of their flowers, and other external marks; and when we examine Linnæus's "Methodi Naturalis Fragmenta," it is evident that in general these were formed on similar grounds; thus we have the order Palmæ, the palm tribe; Orchideæ, from the form and appearance of their flowers; Ensatr, from their sword-shaped leaves, as the iris and cornflag; Tripetaloideæ, from their flowers having three petals only, as in flowering rush, and water plantain; Denudate, from the flower standing up naked from the leaves, as crocus, and meadow saffron; Spathacer, the flowers rising from a spathe or sheath, as snowdrop, and narcissus; Coronarix, from their garland-like heads of flowers, as hyacinth, and asphodelea; Liliaceæ, as the lily and tulip; Calamariæ, from their pen-like stem, as bullrush and sedges; Gramina, grasses; Coniferæ, the pine tribe; Amentacex, from their bearing amenta or catkins, as the birch, willow, and hazel; Dumosæ, from their underwood, or bushy growth, as Laurustinus; Composita, the flowers being compounded 
in a particular way of many smaller ones, as dandelion, daisy, and marigold; Umbellatre, from their flowers being in umbels, as hemlock, carrot, and parsley; Multisiliquæ, from the seed-vessels being numerous and pod-like, as in columbine and ranunculus; Bicornes, from their two-pointed anthers, as in heath and bilberry; Campanacex, from their bell-shaped flowers, convolvulus; Luridx, from their lurid aspect, as night-shade, and henbane; Pomaceæ and Drupaceæ, from their fruit, as apple, pear, almond, plum, cherry; Stellate, from the whorled disposition of the leaves, as in wood-roof, and Robin-run-in-the-hedge, \&c.

I have now given enough to shew that Linnæus, in his Fragmenta, considered that natural orders (were the hopeless task to be attempted of forming such) ought to be founded on striking or evident external characters; and this is all I wish to make appear. They were given in the "Philosophia Botanica" as hints of the way in which natural orders should be formed. They are very imperfect, as he always declared; and some of them contain genera for which no reason can be given why they are located in the place they hold; but yet he scarcely would have brought together into the same order plants so wholly unlike each other as many we find associated in the systems of the present day: for instance, the snowdrop with the American aloe; the tulip and lily with butcher's- 
broom; the mulberry with the fig; the castor-oil tree with the box; chickweed with the gaudy pink and lychnis; the snapdragon and digitalis with the beautiful veronica and globe buddlea the honeysuckle with the laurustinus and the elder; the lime tree with the corchorus; or the hardy and evergreen ivy with the delicate and lowly moschatel. In an artificial system it matters not how incongruous may be the species included in any class or order; but to find such as the above, and hundreds of others, in systems professing to arrange together such plants as are " more like to each other than to any thing else," is certainly somewhat of the wonderful.

One of the greatest charms attached to the study of botany is its giving an interest of the deepest kind to our rambles in the country. A love of plants leads us to an enthusiastic admiration of nature, as her beauty or workmanship are displayed in their formation; but still it is not, perhaps, more the love of the objects as such, than the circumstance that their study leads us into every variety of the diversified scenery of the landscape. It affords a constant attraction to the mind, of the most agreeable description, and affords a pleasure in its pursuit that is ever permanent. Whatever, indeed, will pleasurably tempt us to visit the scenes of nature, will bring with it its reward of happiness; and to this, I 
believe, is owing the enthusiasm of the angler, in following his favourite occupation. It is not merely the capture of a few fish that delights him, but that it leads him into the lovely scenery of the country, wherever mountains rise and waters flow, whether through meadows rich with verdure, or along the more sequestered course of rivers, bounded by heath-covered hills, among which they brawl over stones and rocks, or plunge headlong raging and foaming down the dark and gloomy precipice. This view is beautifully placed before us by a modern writer on the art of angling:_ " What angler," he asks, "will acknowledge other pleasures equal to his own? Yet it is not the sport alone which draws us with magnetic influence to fix us spell-bound by the river's side. No; we have yet a brighter source of true enjoyment in the pure air and tranquil country scenes which wait upon our wanderings. One while amid the wildest sources of the mountain stream; anon beside the lovely lowland river. Now tempting its placid depths of pool, its freshening runs, its eddying, gurgling, glistening rockholes; or pausing to admire the majestic plunge of some adjacent waterfall. What is so beneficial to a body worn with the many cares of study, or close application to a worldly calling, as the free relaxation in which we revel when we quit the noise and bustle of the crowded town to fuast 
upon the mountain breeze? Or what can be so renovating to the wearied mind as to contemplate nature's loveliness with placid thoughts, which gladden and improve the heart, and turn its peaceful reveries in gratitude to nature's God." *

Another writer on the art of angling observes, that "the studious man of whatever profession, although perfectly conscious of the necessity of air and exercise to the preservation of health, has seldom sufficient resolution to tear himself from his accustomed pursuits, without some powerful stimulus to action; and therefore any pleasurable recreation that may induce exercise, and lead the sedentary to the enjoyments of a pure air, breathing over woods, meadows, and waters, cannot fail to be beneficial. I am not acquainted with any amusement in which this advantage can be en joyed without considerable alloy, except the diversion of angling." $p$

Every writer on this art, I believe, from Izaak Walton to the present day, speaks in a similar strain. It is not the paltry taking of a few trout that constitutes the charm of the pursuit; this originates in the impressions formed on the mind by the various scenes of nature into which the

* The Illustrated Fly-fishers' Text-book, p. 1.

$\dagger$ British Anglers' Manual, by T. C. Hofland, Esq., Introduction, p. xi. 
angler is drawn in following up his pastime; and to feelings of similar origin we may trace much of the pleasure arising from the pursuit of any branch of natural history, and more especially, perhaps, of Botany. It is true, indeed, that the study of the productions of nature may be delightful under any circumstances; and that the inhabitant of a crowded metropolis may pursue it with the greatest ardour; but still the investigation of nature in her own domain has additional charms; and however much we may admire the beauty of natural objects, of shells, for instance, in the cabinet of a naturalist, or in a public museum, would we not receive a still greater enjoyment, could we observe them in their native habitats? or in collecting them ourselves on the shores where they had been left by the ebbing tide, or thrown up by some recent storm? The pursuit of natural history, indeed, is in all circumstances redolent of pleasure to its cultivators; that is, when they are fairly warmed with the subject, and possessed of that degree of enthusiasm, without which every pursuit is stale, flat, and unprofitable.

From the passages I have given, it will be apparent that few pursuits can be more delightful than angling is to those who have acquired a passion for it; yet I would hold it at a very low level compared with the occupations of the na- 
turalist. That it has its undeniable pleasures, however, and that these arise in a great measure from the scenery in which the "brothers of the angle" exercise their art, there can be no question; and from that consideration I have referred to this favourite and absorbing pursuit. But while the study of nature leads us, like the pastime of the angler, from the crowded haunts of men into the quiet of the country, it has before it an unbounded sphere of thought and contemplation, and this advantage besides, that it is the source not merely of a temporary, but of the most permanent pleasure. When a botanist at any time examines the contents of his herbarium, there is scarcely a specimen there that does not recall to his memory the period, place, and other circumstances connected with the gathering of it; he lives over again, as it were, the time at which he discovered this plant or that, and when winter comes

"With all his rising train Vapours, and clouds, and storms,"

he is led by the vivid impressions of memory to recall the summer, enjoy its sunshine, breathe the mountain air, wander in the gloom of woods and glens, and in viewing his sea-plants, listen to old ocean's waves weltering on his rugged shores. And though we should know plants by their 
names only, yet that is a knowledge of no mean importance, since in thus being acquainted with them there is a positive and absolute pleasure, even should we go no farther; though one thing is certain, that, unless we know their names in the first place, we have no key by which to find out their history and properties, while it is only by this that the young botanist will be inspired with such a degree of enthusiasm as may lead him on to a deeper study of the science, which will be more especially the case if he can find out their names for himself, and that, no system ever invented will enable him to do, except the Linnæan.

I must now observe that I have no knowledge whatever of Dr. Lindley, except through his publications; and the commenting on these, as I have done, has been any thing but pleasurable, and not written without regret; but when I saw that the taste for botany, as a popular pursuit, was almost entirely gone, - when I read the triumphant assertions of so able and determined an advocate of natural systems, that the Linnxan had exercised the most baneful influence on botany, -- that it was doubtful whether it even deserved a place among the sciences, -- that the time had arrived " when the ingenious expedient of Linnæus, which could only be justified by the state of botany when he first entered upon his career, must be 
finally relinquished," - that in fifteen years he (Dr. Lindley) had rendered the once popular but superficial and USELEsS system of Linnæus a mere matter of history, --in fact, that it was entirely exploded, and had disappeared as completely from the face of the earth as the ancient capital of Priam, \&c. \&c., - I considered myself fairly entitled to express my opinions and feelings on the subject.

Though I had for a long period been attending little to botanical pursuits, I thought of inquiring into these natural systems, with the impression on my mind, that I was to find something of the highest benefit to every thing connected with botanical science; but great, certainly, was my disappointment, on finding them a chaotic mass of contradictions, their boasted advantages a mere fable, and the high praises bestowed on them having the most shadowy foundation. But even supposing that all had been true that was reported of them, I could not comprehend why the system of Linnæus, - the only one that has ever been contrived for leading us easily to the names of plants, - should meet with such a load of abuse, - that it was not science at all, but a useless weed, and now a mere matter of history intended only for times of ignorance, but not adapted to the requirements of the present enlightened generation: nor can I comprehend it yet. Were the 
advocates of the misnamed natural systems afraid, that unless Linnaan botany were quite extinguished, it might lessen their consequence, be a bar to their ambition, divide the sceptre of Flora, and prevent or retard their attainment of supreme authority, rule, and dictation in the botanical world? Dr. Iindley tolls us, as has been already stated, that "whatever the future intentions of a student of botany may be, it is indispensable that the first step to be taken should be that of gaining an acquaintance with the common plants of his own country. In the absence of that he cannot make a single move in advance." - (School Botany, Preface, p. iv.) Why then should the student be robbed of the means of doing so by debarring him from the only resource he may have within his reach? namely, the Linnæan classification, and a Linnæan Flora. But Dr. Lindley says that "when students do not enjoy the advantage of a competent teacher, their best plan will be to put this book (the School Botany) into the hands of an intelligent gardener, and to induce him to furnish them weekly with the plants that are named in it." Now if this volume could find its way to every corner of Great Britain and Ireland, and if in each of these there could be found an intelligent gardener to furnish specimens for a con-si-de-ra-tion, like old Trapbois in the "Fortunes of Nigel," I will 
grant that it might lead to a knowledge of the names of some plants; but the great advantage of the Linnæan system is, that the student can by it teach himself in places where a gardener was never heard of within fifty miles, and that it can be used by persons to whom it might be inconvenient to pay a consideration for the specimens alluded to. From the inveteracy with which this author constantly speaks of the system of Linnaus, one might suppose that its suppression formed almost the paramount object of his life, and some of his favourers have been sufficiently urgent in supporting his endeavours in that respect. Thus the late justly celebrated and indefatigable $\mathrm{Mr}$. Loudon, in a notice of an Introductory Lecture, delivered by Dr. Lindley in the London University in April, 1829, says, "we cannot too much applaud Mr. Lindley for adopting the natural system, which, we believe, has already been done by Professor Henslow at Cambridge: it will mark an era in the history of botany in this country, and redound to the honour and advantage both of Mr. Lindley and the London University. Even if the Limnaan system cannot be done without, or, as most botanists think probable, will never be wholly dispensed with as an easy index for determining the names of individual species, still it is worthy of the ambition of a man of Mr. Lindley's learning, talents, and industry, 
to teach that system which is avowedly the most difficult; the Linnæan being, in truth, so easy that any one who has a book introductory to it, and leisure to walk in the fields, may learn it by himself. We have not a doubt of Mr. Lindley's complete success in every sense in which the word can be taken, and we desire it with all our hearts for his high spirit."**

I suppose that except botany there never yet has been any branch of knowledge, the teaching of which has been applauded on account of the teacher adopting the most difficult method. It usually is the highest recommendation of a teacher, whether professor or schoolmaster, that he has an easy way of initiating his pupils in a knowledge of the subject, whatever that may be which he professes to teach; but in every thing relating to botany on the natural scheme a departure from ordinary rules is the fashion of the day. Here we are told that any one who has a book introductory to Linnæan botany, and leisure to walk in the fields, may learn it by himself; but nevertheless the professor is applauded for his teaching what very few could comprehend, and told that his doing so will redound not only to his own honour but that of the London University. Mr. Loudon has said that it is worthy

* Loudon's Gardener's Magazine, vol.v. p. 328. 
of the ambition of a man of the professor's learning, talents, and industry, to teach that system which is avowedly the most difficult. I must again repeat that I know nothing of the professor except from his writings; and I trust this opinion of Mr. Loudon's, so strongly expressed with regard to ambition, is erroneous; I should think it equally worthy of a man's ambition, equally honourable, and certainly more equitable, to attempt the diffusion of knowledge by the easiest means, than to gain the highest name at the risk of destroying all general taste for the cultivation of one of the loveliest of the sciences.

I now conclude these observations by hoping that the time may yet come when Linnæan botany will regain its former splendour, and that, to use the words of the great Boerhave, as applied by him to it, "ages to come will applaud, good men will initate, and all will be improved."

III END. 


\title{
NEW WORKS
}

\section{In MISCELLANEOUS and GENERAL LITERATURE,}

\author{
PUBLISHED BY
}

Messr. LONGMAN, BROWN, GREEN, AND LONGMANS,

PATERNOSTER ROW, LONDON.

\section{CLASSIFIED INDEX.}

AGRICULTURE \& RURAL AFFAIRS. Crocker's Land Surveyiug - - - 10

Davy's Auricultural Chemistry - - 10 Fresenius' - - 12 Johnson's Farme"r's Encyclopæedia - - 16 Loudon's Encyclopadia of Arriculture - 19 ,$\quad$ Self-lnstruction for Farmers, etc. 18 (Mrs.) Lady's Country Companion $] 8$ ow's Breeds of the Domesticated Animals 20 , Elements of Agriculture - - 20 , On Landed Property - _ . 19 $\because$ Onthe Domesticated Animals - 19 Parnell on Roads - _ _ _ - 24 Stewart on Trausfer of Landed Property 29 Thomson on Fattening Cattle, etc. $\quad 30$ Topham's Agricultural Chemistry • 31

\section{ARTS, MANUFACTURES, AND ARCHITECTURE.}

Ball on the Mallufacture of Tea

Brande's Dictionary of Science, ete.

Budye's Miner's Guide

Cartoons (The Prize)

Cresy's Encycl, of Civil Engineering

D'A gincourt's History of Art -

Dresden Gallery

's ugar Planter's Manual -

Gwilt's Encyclopiedia of Architecture - 13

Haydon's Lectures on Painting \& Design 13

Holland's Manufactures in Metal - 17

Jameson's Sacred and Legendary Art - 15

Loudon's Rural Architecture - - $\quad 19$

Moseley's Enyineering and Architecture 23

Parnell on Roads - - - - - 24

Porter's Manufacture of Silk - - $\quad 17$

" " Porcelain \& Glass 17

Reid'(Dr.) on Warming and Ventilating 25

Stean Engine (The), by the Artisan Club 5

Ure's Dictionary of Arts, etc. - - 31

Wood on Railroads - - - - $\quad$ - 32

\section{BIOGRAPHY.}

Andersen's (H.C.) Autobiography $\quad 5$ Bell's Lives of the British Poets - - 17 Dunham's Farly Writers of Britain - 17 , Lives of the British Iramatists 17 Forster's Statesmen of the Commonwealth 17 '" Life of Jebb - - - - 17 Gleig's British Military Commanders - 17 Gra!it (Mrs.) Memoir and Correspondence 12 Haydon's Autobingraphy and Journals - 13 Janes's Life of the Black Prince - - 15 "Eminent Foreicn Statesmen Kindersley's De Bayard $-\quad-\quad 18$ Mackiutosh's Life of Sir T. More - $\quad 20$ Maunder's Biographical'Treisury - $\quad 22$ Roscoe's Lives of Eminent British Lawyers 17 Russell's Bedford Correspondence Schopenhatier's Youthful Life - - $\quad 27$ Shelley's Literary Men of Italy, etc. $\quad-17$ Eminent French Writers - 17 Southey's Lives of the British Admirals - 17 , Life of Wesley - • - - 29 Taylor's Loyola - _ _ _ - $\quad 30$ Townsend's Twelve eminent Judges - 31 Waterton's Autobiography and Essays - 32

\section{BOOKS OF GENERAL UTILITY.}

Acton's (Eliza) Cookery Book - . Black's Treatise on Brewing - * - $\quad 6$ Cabinet Lawyer (The) - - - - 8 Collegian's Guide - - - - - 8 Donovan's Dumestic Economy - $\quad 17$ Foster's Hand book of Literature - : 12 Hints on Etiquette - - - • - 13 Hudson's Executor's fivide - - - 15 On Making Wills • - 15 Hume's A rerount of Learned Societies, etc. 15 Loudon's Self Instruction - - - 18 , (Mrs.) dmateur Gardener - 18 Maunder's Treasury of Kl1owledge - - 22 ," Scientificand Literary Treasury 22 "Treasury of History ", Biographical Treasury : : 22 ,$\quad$ Natural History - - -22 Parkes's Domestic Duties • • • 24 Pocket and the Stud _ _ _ - 25 Pycroft's Course of English Reading : 25 . Reader's Time Tables - • - - 25 Rich's Companion to the Latin Dictionary 25 Riddle's Eng.-l,at. and Lat.- Eny. Dict. - 26 Robiuson's Art of Curiıg, Pickling, etc. $\quad 26$ Art of Making British Wines, 26 Rowton's Debater - - - - - 26 Short Whist - - - • • - 27 Suitor's lnstructor ('lhe) - - - 29 Thomson's Management of Sick Room - 30 " Intorest Tables - - • 30 Wcbi"ter's Furycl. of Domestic Economy 32 Zumpt's Latin Grammar - • . . 32

\section{BOTANY AND GARDENING.}

Abercrombie's Practical Gardener - . 5 and Main's Gardener $\quad-5$

Ball on the Cultivation of Tea - $\quad-6$ Crllcott's Scripture Herbal - - - 8 Conversations on Botany - - - 9 Fvans's Sugar Planter's Manual - 11 Henslow's Botany - - - - - 17 Hoare On the Grape Vine on Open Walls 14 ", On the Roots of Vines - - - $\$ 3$ Hooker's British Flora - . - 14 " Guide to Kew Gardens - - - 14 Lindley's 'Tlieory of Horticulture , Orchard aud Kitchen Garden - 18

, Introduction to Botany - - 18

,S Synopsis of British Flora - - 18 Loudion's Hortus Britannicus - : : 19 
Pages Encyclopædia of 'Trees \& Shrubs 19 Encyclopada ordening 19 ", ", $\quad$ Plants $\quad$ : 19 " Suburball Gardener • - 19 ,' Self-Instruction for Gardeners 18 ," (Mr.) Amateur Gardener - - 18 Repton's Landscape Gardening, etc. - 25 Rivers's Rose Amateur's Guide - - 26 Rogers's Vegetable Cultivator - • - 26 Smith's lntroduction to Botany - . 28 , English Flora - - - $\quad$ - 28 ,, Compendium of English Flora - 28

\section{CHRONOLOGY.}

Blair's Chronological Tables Bosanquet's Chronology of Ezra, etc. Bunsen's Ancient F.yypt Nicolas's Chronology of History - 17 Riddle's Ecclesiastical Chronology - 26

\section{COMMERCE AND MERCANTILE AFFAIRS.}

Banfield and Weld's Statistics - - 6 Baylis's Arithmetic of Annuities - $\quad 6$ M'Culloch's Dictionary of Commerce - 20 Reader's Time Tables - - - $\quad-25$ Steel's Shipmaster's Assistant - - - 29 Symonds'Merchant Seamen's Laws - 29 Thomson's Tables of lnterest - . - - 30 Walford's Customs' Laws • • - 31

GEOGRAPHY AND ATLASES. Butler's Ancient and Modern Geography ," A tlas of Modern Geography

," , Ancient Geography

," General Geography De Strzelecki's New South Wales (1) Hall's Large General Atlas - • - 13 $M^{\prime} \mathrm{Culloch}^{3}$ Geographical Dictionary - 20 Mitchell's Australian Expedition : - 22 Murray's Encyclopedia of Geography - 24 Parrot's Ascent of Mount Ararat - - 24 Schomburgk's Barbados, and Map -

HISTORY AND CRITICISM. Bell's History of Russia. Black Prince Blair's Chron. and Historical Tables Bloomfield's Translation of Thucydides Edition of 'Thucydides

Bunsen's Ancient Egypt

Congbeare and Howson's St. Paul -

Cooley's Maritime and Inland Discovery Crowe's History of France

Coulton on Junius's Iuetters - De Sismondi's Fall of the Roman Empire 17 Italian Republics - - 17 Dunham's History of Spain nnd Portugal 17 , Europe in the Mirdle Ages - 17 , History of the German Himpire 17 ", Denmark, Sweden, and Norway 17 ". History of Poland - - - 17 Dunlop's History of Fiction - - 11 Eastlake's History of Oil Painting - 11 Eccleston's English Antiquities - - 11 Foster's European Iiterature - _ - - 12 Fergus's United States of Amcrica - 17 Gibbon's Roman Empire - - - - 12 Grant (Mrs.) Memoir and Corespoudence 12 Grattan's History of Netherlands - 17 Grimbl ot's William III. and Louis XIV. I2 Haisted's Life of Richard III. - - 13 Harrison On the English Language - 13 Haydon's Lectures on Painting and Design ] 3
Histerical Charades

Historical Pictures of the Middle Ages - 13 Jeffrey's iLord) Contributions - - 16 Keightley's Outlines of History - - 17 Laing's Kings of Norway - - - 16 Lemprière's Classical Dictionary - $\quad 18$ Macaulay's Essays - : - $\quad 20$ History of England - - 20 Miscellaneous Works
M'Culloch's Dictionary, Historical, Geo. graphical, and Statistical

Maunder's 'Treasury of History - - 22 Milner's Church History _ _ _ 22 Moore's History of Ireland • • • 17

Mosheim's Ecclesiastical History - $\quad 23$

Nicolas's Chronology of History - $\quad 17$

Passages from Modern History - $\quad$ - 28

Ranke's History of the Reformation - 25

Rich's Companion to the Latin Dictionary 25

Riddle's Latin Dictionaries - $\quad$ - $\quad$ - 26

Romc, History of - - • - : 17

Rowton's British Poetesses - - - 26

Russell's Bedford Correspondence - 6

Scott's History of Scotland - $\quad-17$

Sinnett's Byways of History - - - 28

Southey's Doctor, etc. - - - - 29

Stebbing's Histnry of the Christian Church 17

", Church History - - - 17

Switzerland, History of - $\quad-\quad \cdot \quad-17$

Syduey Smith's Works - - - - 28

Taylor's Loyola - _ _ _ - $\quad-30$

'Thirlwall's History of Greece - . $\quad 30$

Tooke's Histories of Prices - - $\quad$ - 30

Turner's History of England - - - 31

Zumpt's Latin Grammar * : : - 32

\section{JUVENILE BOOKS.}

Amy Herbert - _ $\quad$ - $\quad$ - $\quad 5$

Callcott's Home among Strangers - - 8

- $\quad 12$

Gower's Scientific Plienomena - $\quad$ - 12

Historical Charades - $\quad$ - $\quad$ - 13

Howitt's Boy's Country Book - - - 14

Children's Year : - $\quad-14$

Laneton Parsonage - $-\overline{-} \quad-18$
Mackintosh's Life of Sir 'T. More $\quad-\quad 20$

Marcet's Conversations-

On Clicmistry

On Natural Philosophy

On Political Eeonomy

On Laud and Watology -

Marryat's Nasterman Ready

," Privateer's-Man - . 21

") Settlersin Canada - - $\quad 21$

, Mission; or, Scencs in Africa 21

Passages from Modern History - -28

\section{MEDICINE.}

Bull's Hints to Mothers

", Management of Children

Cópland's Dictionary of Medicine -

Ellıotson's Human Physiology

Holland's Medical Notes -

Lane's Water Cure at Malvern

Latham On Diseases of the Heart

Percira On Food and Diet

Saudby On Mesmerism

Thomson On Food -

\section{MISCELLANEOUS.}

Blcssingtou's Fugitive Fancies

Carey's Past, l'rcscut, and luture Cartoons (The Prize)

Cocks's Bordeaux, its IFines, etc. -

Collegian's Guide 
Colton's Lacon -

Coulton On Authorship of Junius -

De Jaenisch On Chess Openings

De la Gravière's Last Naval W' ar

De Morgan On Probabilitics

De Strzelecki's New South Wales -

Dresden Gallery

Dunlop's History of Fiction

Field On Prison Discipline - $\quad-\quad 11$

Gardiner's Sights iu ltaly - - -1

Gower's Scientific Phellomena - - 1\%

Grahain's Fuglish - - - 1

Gran't's Letters from the Mountains - 12

Hobbes's ('Thos.) complete Works - 14

Hooker's Kew Guide - _ • - 14

Howitt's Rural Life of England - - 10

Visits to Remarkable Places - 14

Student Life of Germany - 15

Rural and social Life of Germally 15

Colonisation and Christianity - 15

Hume's Account of Learned Societies - 15

Jeffrey's (Lord) Contributions - - 16

Lane's Life at the Water Cure - - 16

Loudon's (Mrs.) Lady's Couutry Companion 18

Macaulay's Critical and Historical Essays 20

Mackiutosh's (Sir J.) Miscellaneous Works 20

Maitland's Church in the Catacombs - 21

Necker De Sanssure's on Education - 24

Plunkett On the Navy - - - - 25

Pycroft's Course of English Reading - 25

Rich's Companion to the Latin Dictionary 25

Richter's Levana - - - - - -

Riddle's Latin Dictionaries - - - $\quad 26$

Rogret's Economic Chess-board - $\quad 26$

Rowton's Debater - - - - - 26

Sandy's Mesmerism - - - - - 26

Sandford's Parochialia - - - $\quad$ - 26

Seaward's Narrative of his Shipwreck - 27

Southey's Common.Place Book - - 29

Doctor, etc. - - - - 29

Suitor's Instructor (The) - - - 29

Sunmerly's Sea and Railway - - $\quad$ - 29

Sydney Smith's Works - - • - 28

'Thomson on Food of Animals, etc. - - 30

Wralker's Chess Studies - - - - 31

Willoughby's (Lady) Diary - - - 32

Zumpt's Latin Grammar - - - - 32

\section{NATURAL HISTORY IN GENERAL.}

Catlow's Popular Conchology - - - 8

Doubleday's Butterflies and Moths - 10

Gray aud Mitchell's Ornithology - $\quad 12$

Kïrby and Spence's Entoniology $\quad-\quad$ - 12

Lee's Taxidermy -

, Elements of Natural History - $\quad-18$

Maunder's Treasury of Natural History 22

Stephens' British Beetles - - • 29

Swainson on the Study of Natural History 17

,, Animals : : : : : : 17

,, Quadrupeds - • - - 17

, Birds - - - - -17

,$\quad$ Animals in Menageries $\quad 17$

," Fish, Amphibia, and Reptiles 17

,$\quad$ Insects $\because \quad-\quad-\quad 17$

, Malacology - - - - 17

" Habits and lnstincts - - 17

"Taxidermy - - $-\quad-\mathbf{3}$

Turton's Shells of the British lslands - 31

Waterton's Essays on Natural History - 32

Westwood's Classification of Insects - 32

NOVELS AND WORKS OF FICTION.

Callcott's Home among Strangers - $\quad 8$

Dunlop's History of Fiction - - - 11

Hall's Midsummer Eve - - - 13

Lady Willoughby's Diary _ $\quad$ - $\quad$ - 32

Matame De Malguet • • • - 21
Marryat's Masterman Ready _ $\quad$ Pages

"Privateer's-Mall - - $\quad-2$

") Settlcrs in Canada - - - 21

"Mission; or, Scenes in Africa - 21

Pericles, a Tale of Athens - - $\quad-24$

Southey's Doctor, etc. - - - - 29

Twelve Years Ago - _ _ _ _ _ 31

\section{ONE VOLUME ENCYCLOPAEDIAS AND DICTIONARIES.}

Blaine's, of liural Sports - • - •

Brande's, of Sciencc, Literature, and Art 7

Copland's, of Medicine - $\quad$ - $\quad-9$

Cresy's, of Civil Fingineering - - $\quad-9$

Gwilt's, of Architecture - - - - 13

Johnson's Furmer - - - - - 16

Loudnn's, of 'Trees and Shrubs - - 19

, of Gardening - - _ - 19

,, of Agriculture - - - - 19

", of Plants - - - - - 19

, of Rural Architecture - $\quad$ - 19

M'Culloch's Geographical Dictionary - 20

, Dictionary of Commerce - 20

Murrä's Fncyclopadia of Geography - 24

Ure's Arts, Mallufactures, and Mines - 31

Webster's Domestic Ecollomy - 32

POETRY AND THE DRAMA.

Aikin's (1)r.) Britislı Poets - - - 27

Chalenor's Walter Gray - - - $\quad-8$

Collier's Roxburghe Ballads - - - 9

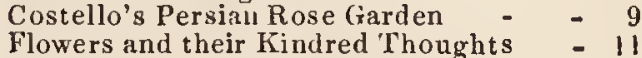

Goldsmitl's Poems, illustrated - - 12

Gray's Elegy, illuminated - - - 12

Howitt's (Mary) Ballads - - - - 14

L. E. L.'s Poetical Works - - - 16

Linwood's Anthologia Oxoniensis - - 18

Macaulay's Lays of Ancient Rome - $\quad 20$

Mackay's English Lakes - • • - 20

Montgomery's Poetical Works - - 23

Moore's Irish Melodies - • - - 23

" Lalla Rookh - - _ - 23

Moralical Works - $\quad-\quad$ - 23

Rowton's Britisli Poetesses - $\quad-\quad-26$

Shakspeare, by Bowdler - - - 27

Sophocles, by Linwood - • - - 28

Southey's Poetical Works : - : 29

Spirit of the British Poets - - - - 27

Thomson's Seasons, illustrated $\quad-\quad-30$

", with Notes, by Dr. A. T. Thomson 30

\section{POLITICAL ECONOMY AND STATISTICS.}

Banfield and Weld's Statistics - -

M'Culloch's Gcographical, Statistical, and

Historical Dictionary $\quad-\quad-\quad-20$

M.Culloch's Dictionary of Commerce - 20 " Literature of Polit. Economy 21

"On Succession to Property - 21

" On Taxation and Funding - 21

", Statistics of the British Empire 20

Marcet's Conversations on Polit. Economy 21

Symonds' Merchant Seamen's Law - 29

'Tooke's Histories of Prices - - - 30

Twiss's (Dr.) View of Political Economy 31

, Schleswig-Holsteiı Question 31

\section{RELIGIOUS AND MORAL} WORKS, ETC.

Amy Herbert, edited by Rev. W. Sewell

Barrett's Old'Testament Criticisms . - 

, College and School ditto ," LexicoutoGreek Testament Bunsen's Church of the Future Burder's Oriental Customs Burus's Christian Philosophy

Christian Fragments Call'cott's Scripture Herbal Closing Scenc

Conybeare and Howson's St. Paul Cooper's Sermons Coquerel's Christianity

Dale's Vomestic Liturgy

Dibdin's Sunday Library

Discipline

Englishman's Hebrew Coucordance Greek Colicordancc

Forster's Historical Geography of Arabia Life of Bishop Jebb

From Oxford to Rome - _ - - 12

Gertrude, edited by the Rev. W. Sewell - 12

Hook's (Dr.) Lectures on Passion Week 14

Horne's I introduction to the Scriptures - 14

" Compendium of ditto - $\quad 14$

Jameson's Sacred and Legendary Art - 15

Jebb's Correspondence with Kıox - - 15

17i" Translation of the Psalms - - 16

Kip's Christmas in Romc - - : - $\quad-16$

Laneton Parsonage - _ _ _ - 18

Letters to my Unknown Friends - - 18

Maitland's Church in the Catacombs - 21

Margaret Percival - - -

Milner's Church History -

Miracles of Our Saviour

Moore on the Power of the Soul

" on the Use of the Body

" on Man und his Motives

Mosheim's Ecclesiastical History

Parables of Our

Parkes's Domestic Duties -

Pitman's Sermons on the Psalms

Ranke's Reformation - -

Renaud's Matutina

Rest in the Church

Riddle's Lctters from a Godfather.

Sandford On Female Improvement -

$$
\text { , On Woman }
$$

Sermon on the Mount (The)

Shurammite (The Good) -

Sinclair's Jouruey of Life

"ketches (The)

$$
\text { Business of Life }
$$

Smith's (G.) Perilnus Times Religion of Ancient Britain Siced Annils

", (J.) St. Paul's Shipwreck

Soames's Latil Church

Southey's Life of Weslcy

Stebbing's Christian Church - - - 17 Reformation - - - -17

Stephen's Church of Scotland _ $\quad-29$

Sydney Smith's Sermous - - - 28

Tate's Hiktory of St. Paul - $\quad$ - $\quad 29$

Tayler's. (Rev. C. B.) Margaret - - 30

Taylor's (Jeremp) Works - - - $\quad 30$

. (Isaac) Loyola - $\quad-\quad-30$

Tomline's Introduction to the Bible $\quad-30$

Turner's Sacred History - - - 31

Twelve Years Ago - _ _ _ - 31

Walker's Elementa Liturgica - - $\quad$ - 31

Wardlaw On Sociniau (iontroversy - 31

Wilberforce's View of Christianity $\quad-32$

Willoughby's (Lady) Diary - - . 32

Wilson's Lands of the Bible - _ - 32

Wisdom of Johuson's Rambler, etc. - 16

Woodward's Sermons alld Essays - _ 32 ,S Sequel to Shunammite

\section{RURAL SPORTS.}

Blaine's Dictionary of Sports

Ephemera on Angling

Hawbuck Grange

Hawker's Instructious to Sportsmen

Jones's Norway Salmon Fisher

Pocket and the Stud

Stable Talk and Table Talk

Pages

- 11

- 13

$-13$

$-16$ AND MATHEMATICS.

Baker's Railway Engineering -

Bakewell's Introduction to Geology - 5

Brande's Dictionary of Science, etc. - 7

Brewster's Optics

Conversations on Mineralogy - $\quad-9$

De la Beche on the Geology of Cornwall, etc.10

Donovan's Chemistry. - - - 17

Farey on the Steam Hingine - $\quad-\quad 11$

Fosbroke on the Arts of the Ancient: - 17

Gower's Scientific Phenomena - - 12

Herschel's Natural Philosophy - - $\quad 17$

Holländ's Astronomy - - - - 17

Humboldt's Cosmos - - - - 15

Hunt's Researches on Light - - : 15

Kater and Lalduer's Mechanics _ $\quad-17$

Lardner's Cabinet Cyclopredia - - 17

"Hydrostatics and Pncumatics - 17

, and Walker's Electricity $\quad 17$

", Arithmetic - - - - 17

" Geometry - - - - 17

Low's Chemistry - - - - $\quad-19$

Marcet's Conversations on the Sciences 21

Mattencci () n Physical Phenomena - . 21

Memoirs of the Geological Survey - $\quad 22$

Moseley's Practic.al Mlechanics

Fingineering and Architecture 23

Owen's Iectures On Comparative Anatomy 24

Peschel's Physics - _ _ - - 24

Phillips's Palieozoic Fossilsof Cornwall, etc. 24

" Miseralogy, by Prof. Miller - 25

Treatise on Geology - $\quad-\quad-17$

Portlock's Geology of Londonderry - 25

Powell's Natural Philosophy - - $\quad 17$

Ritchie (Robert) on Railways - - 26

Topham's Agricultural Chemistry - $\quad 31$

Borrer's Campaigu in Algeria -

Costello's (Miss) North Wales

Coulter's California, etc.

S'Pacific - - - - -9

De Strzelec(ki's New South Wales - $\quad 10$

Dunlop's Central America - _ - 10

Ermans Travels through Siberia - - 11

Gardiller's sights in Italy - _ - 12

Harris's Highland s of Ethiopia - - 13

Jones's Norway Guide - - - - 16

Kip's Holyduys in Rome - - - 16

Laing's Tourin Sweden - $\quad$ - 16

Mackay's Finglish Lakes - $\quad-\quad 20$

Marryat's Borneo - - _ _ - $\quad 21$

Mitchell's Expedition into Australia - 22

Parrot's Ascent of Mount Ararat - $\quad 24$

Schomburgk's Barliados - - $\quad 27$

Schopeuhauer's Pictures of Travel - $\quad-27$

Seavard's Narrative of his Shipwreck - 27

Tischeudorf's Travels in the East - $\quad 30$

Von Orlich's Travels in lindia _ _ 31

Wilson's Travels in the Holy Land

$-32$

Milles On the Horse's Foot

Pocket and the Stud

Stable Talk and Trable Tretk

Thomson on Fattening Cattle

Winter On the Horse 


\title{
NEW WORKS AND NEW EDITIONS
}

\author{
PUBLISHED BY
}

Messrs. LONGMAN, BROWN, GREEN, AND LONGMANS.

\section{ACTON (MISS).-MODERN COOKERY,}

In all its Branches, reduced to a System of Easy Practice. For the use of Private Families.

In a Series of Practical Receipts, all of which have been strictly tested, and are given with the most minute exactness. By Filiza Acton. New Edition, to which are added, Directions for Carving. Foolscap 8vo. with Plates and Woodcuts, 7s.6d. cloth.

"The whole of Miss Acton's recipes ' with a few trifling exceptions, which are scrupulously specified, are confined to such as may be perfectly depended on, from having been proved beneath our own roof, and under our own personal inspection.' We add, moreover, that the recipes are all reasonable, and never in any instance extravagant. They do not bid us sacrifice ten pounds of excellent meat, that we may get a couple of quarts of gravy from it; nor do they deal with butter and eggs as if they cost nothing. Miss Acton's book is a good book in every way; there is right-mindeduess in every page of it, as well as thorough $k$ nowledge and experience of the subjects she handles."-Medical Gazette.

\section{ABERCROMBIE.-ABERCROMBIE'S PRACTICAL GARDENER, AND} IMPROVED SYSTEM OF MODERN HORTICULTURE, alphabetically arranged. New Edition, with an Introductory Treatise on Vegetable Physiology; and Plates by W.Salisbury. $12 \mathrm{mo} .68$. boards.

\section{ABERCROMBIE AND MAIN.-THE PRACTICAL GARDENER'S COM-} PANION; Or, Horticultural Calendar: to which is added, the Garden-Seed and Plant Estimate. Edited, from a MS. of J.Abercrombie, by J. Main. New Edition. 32mo.2s.6d. sewed.

\section{ALLAN (J. H.)-A PICTORIAL TOUR IN THE MEDITERRANEAN;}

Comprising Malta, Dalmatia, Turkey, Asia Minor, Grecian Archipelago, Egypt, Nubia, Greece, Sicily, Italy, and Spain. J.H. Allan. New Edition. Imperial 4to. with upwards of 40 lithographed Drawings, and 70 Wood Engravings, $3 l .3 s$. cloth.

\section{AMY HERBERT.}

By a Lady. Edited by the Rev. William Sewell,B.D. of Exeter College, Oxford. New Edition. 2 vols, foolscap 8 vo. 9 s. cloth.

\section{ANDERSEN.-THE TRUE STORY OF MY LIFE;}

A Sketch. By Hans Christian Andersen, author of "The Shoes of Fortune," "The Nightingale," "O.T.," "Only a Fiddler," "The Improvisatore," etc. Translated by Mary Howitt. Fcp. 8vo. 5s, cloth.

\section{ARTISAN CLUB (THE).-A TREATISE ON THE STEAM-ENGINE.}

In its application to Mines, Mills, Steam Navigation, and Railways. By the Artisan Club. Edited by John Bourne, C.E. New Edition. 4to. with 30 steel Plates, etc., and about 350 Wood Engravings, 27s, cloth.

\section{BAKER.-RAILWAY ENGINEERING;}

Containing the most approved Metbods of laying out Railway Curves, and of setting out the Cuttings, Embankments, and Tunnels of Railways: with a General and two Auxiliary'Tables, for the Calculation of Earthworks of Railways, Canals, etc. Also, the Investigation of the Formula for the Superelevation of the exterior Rail in Curves. By T. Baker, Surveyor and Civil Engineer. 8vo.5s, cloth.

\section{BAKEWELL.-AN INTRODUCTION TO GEOLOGY.}

Intended to convey Practical Knowledge of the Science, and comprising the most important recent Discoveries, By Robert Bakewell. Fifth Edition, 8vo. witl Plates and Woodcuts, 21s. cloth. 
BALL.-AN ACCOUNT OF THE CULTIVATION AND MANUFACTURE OF TEA IN CHINA: derived from Personal Observation during an Official Residence in that Country of upwards of Twenty Years; and illustrated by the best Authorities, Chinese as well as European. With some Remarks on the Expcriments now making for the Intro* duction of the Culture of the Tea Tree in other parts of the World. By S. Ball, Esq. late Inspector of Teas to the East India Company in China. 8vo. with Plates and Woodcuts, 14s. cloth.

BANFIELD AND WELD.-THE STATISTICAL COMPANION;

Fxhibiting the most interesting Facts in Moral and Intellectual, Vital, Hiconomical, and Political Statistics, at home and abroad. Compiled from Official and other authentic Suurces, by T. C. Banfield, Statistical Clerk to the Council of Education; and C. R. Weld, Assistant Secretary to the Royal Society. Foolscap 8vo. 5s, cloth.

\section{BARRETT.-A SYNOPSIS OF CRITICISMS}

Upon those Passages of the Old Testament in which Modern Commentators have differed from the Authorized Version: together with an Explanation of various Difficulties in the Hebrew and English Texts. By the Rcv. Richard A. F. Barrett, M.A. Fellow of King's College, Cambridgc. Vols. I. and 1I. 8vo.28s. each cloth; or in 4 Half-vols. 14s. each. Also, Half-vol. V. 14 s.

\section{BAYLDON.-THE ART OF VALUING RENTS AND TILLAGES,}

And the Tenant's Right of Entering and Quitting Farms, explained by several Specimens of Valuations; and Remarks on the Cultivation pursued on Soils in different Situations. Adapted to the Use of Landlords, Land-Agents, Appraisers, Farmers, and Tenants. By J.S. Bayldon. New Edition, corrected and revised by John Donaldson. 8vo.10s.6d. cloth.

BAYLIS.-THE ARITHMETIC OF ANNUITIES AND LIFE ASSURANCE ; Or, Compound Interest simplitied. Explaining the Value of Annuities, certain or contingent on One or Two Lives, and the Values of Assurances in Single and Annual Payments; and comprehending Leases, Pensions, lireeholds, and Reversionary Sums, etc. By Edward Baylis. 8vo. 5s, cloth.

BEDFORD CORRESPONDENCE. - CORRESPONDENCE OF JOHN, FOURTH DUKE OF BEDFORD, selected from the Originals at Woburn Abbey, $(1742-50)$. With Introductions by Lord John Russell. 3 vols. 8 vo. 48 s. cloth.

$$
\text { ** Vol. I. (1742-48), 18s.; Vol. II. (1749-60), 17s.; Fol. III. (176I-70), 15s. }
$$

\section{BLACK PRINCE.-A RECORD OF THE BLACK PRINCE;}

Being some of the most striking Passages of his Life-in the Words of his Chronjelers, selccted more espccially from the records of his contemporary Froissart, in the quaint and spirited translation made by Lord Berners for King Henry V111. Post 8vo., printed in black letter, cmbellished with llluminated Borders and Miniatures, and bound in imitative carving.

[In the press.

\section{BLACK.-A PRACTICAL TREATISE ON BREWING.}

Based on Chemical and Economical Principles: with Formulie for Public Brewers, and Instructions for Private Families. By William Black. Third Edition, revised and corrected, with considerable Additions. $8 \mathrm{vo} .10 \mathrm{~s} .6 \mathrm{~d}$. cloth.-Also,

SUPPLEMENT, of REMARKS on BAVARIAN BEER, etc. 8vo.2s.6d. sewed.

\section{BLAINE.-AN ENCYCLOPFDIA OF RURAL SPORTS ;}

Or, a complete Account, Historical, Practical, and Descriptive, of Hunting, Shooting, Fisning, Racing, and other Field Sports and Athletic Amusements of the present day. By Delabere P. Blaine, Esq., author of "Canine l'athology," etc. With nearly 600 Engravings ou Wood, by R. Bransto11, from Drawings by Alke1, T. Landseer, Dickes, etc. 8vo. 50s. cloth.

\section{BLAIR'S CHRONOLOGICAL AND HISTORICAL TABLES,}

From the Creation to the present Time: with Additions and Corrections from the mostauthen. tic Writers; including the Computation of St. Paul, as connecting the Period from the Fxode to the Temple. Under the revision of Sir Henry Ellis, K.H., Principal Librarian of the British Museum. Imperial 8vo. 31s.6d. half-bound morocco.

BLESSINGTON.-FUGITIVE FANCIES.

By the Countess of Blessington. Fcap. 8vo.

[In the press.

BLOOMFIELD. -THE HISTORY OF THE PELOPONNESIAN WAR.

By Thucydides. A New Recension of the Text, with a carcfully amended Punctuation; and copious Notes, Critical, Philological, and Explanatory, almost entirely original, but partly sclected and arranged from the best Expositors : acconpanied with tull Indexes. Illus trated by Maps and Plans. By the Rev.S.'T. Bloomfield, D.D. F.S.A. 2 vols. 8vo. 38s. cloth. 
BLOOMFIELD.-THE HISTORY OF THE PELOPONNESIAN WAR.

By Thucydides. Translated into English, and accompanied with very copious Notes, Philological and Explanatory, Historical and Geographical. By the Rev.S.T. Bloomfield, D.D.F.S.A. 3 vols. 8 vo. with Maps and Plates, $2 l .5 s$. boards.

\section{BLOOMFIELD.-THE GREEK TESTAMENT :}

With copious English Notes, Critical, Philological, and Explanatory. Formed for the use of advanced Students of Divinity and Candidates for Holy Orders. By the Rev. S. T. Bloomfield, D.D. F.S.A. New Edition. 2 vols.8vo. with a M ap of Palestine, 40 s. clotl.

BLOOMFIELD. - THE GREEK TESTAMENT FOR COLLEGES AND SCHOOLS; with shorter English Notes, Critical, Philological, and Explanatory. By the Rev. S. T. Bloomfield, D.D. New Edition, enlarged, with a New Map and an Iudex, Foolscap 8ro. 10s. 6d. clotll.

\section{BLOOMFIELD.- GREEK AND ENGLISH LEXICON TO THE NEW} TESTAMENT: especiallv adapted to the use of Colleges, and the Higher Classes in Public Schools; but also intended as a convenient Manual for Bibljcal Students in general. By Dr. Bloomfield. New Edition, improved. Foolscap 8vo. 10s.6d. cloth.

\section{BORRER.-NARRATIVE OF A CAMPAIGN WITH A FRENCH COLUMN,} under Maréchal Bugeaud, directcd against the Kabiles of Algeria : together with an A ccount of the Adventures of M. Suchet in search of the Camp of the Emir Abd-el-Kader. By Dawson Borrer, F.R.G.S. Membre Correspondant de la Société Orientale à Paris, autlior of "A Journey fron Naples to Jerusalem." Post Svo.

[Nearly ready.

BOSANQUET.-CHRONOLOGY OF THE TIMES OF DANIEL, EZRA, AND NEHEMIAH, considered with the view of correcting an Firror of Thirty-thrce Years in the received Chronology between the Capture of Jerusalem by Nebucliadnezzar and the Birth of Christ. Leading to an Fixplanation of the Prophecy of the Seventy Weeks, thc Recovery of the lost Era of the Jubilee, and the Rectification of several important Dates in Scripture Chronology. By J. Whatman Bosanquet, Esq. Part I. 8vo.8s.6d. cloth.

\section{BRANDE.--A DICTIONARY OF SCIENCE, LITERATURE, AND ART;}

Comprising the History, Description, and Scientific Principles of every Branch of Human Knowledge ; with the Derivation and Definition of all the Terms in general use. Edited by W.T. Brande, F.R.S.L.and E.; assisted by Dr.J. Cauvin. 8vo. with Woodcuts, $3 l$. cloth.

\section{BUDGE (J.)-THE PRACTICAL MINER'S GUIDE.}

Comprising a Set of Trigonometrical Tables adapted to all the purposes of Oblique or Diagonal, Vertical, Horizontal, and Traverse Dialling; with their application to the Dial, Exercise of Drifts, Lodes, Slides, Levelling, Inaccessible Distances, Heights, etc. By J. Budge. New Edition, enlarged. 8vo. with Portrait, 12s, cloth.

\section{BULL.-HINTS TO MOTHERS,}

For the Management of Health during the Period of Pregnancy and in the Lying-in Room; with an Exposure of Popular Errors in counexion with those subjects. By'Thomas Bull, M.D. New Edition, revised and considerably enlarged. Foolscap 8 vo.78. cloth.

\section{BULL. - THE MATERNAL MANAGEMENT OF CHILDREN,}

In HFALTH and DISEASE. By Thomas Bull, M.D. Physician Accoucheur to the Finsbury Midwifery Institution, etc. New Edition, revised and enlarged. Foolscap 8vo.5s. cloth.

BUNSEN.-THE CONSTITUTION OF THE CHURCH OF THE FUTURE. A practical Explanation of the Correspondence with the Right Hon. William Gladstoue, on the German Church, E piscopacy, and Jerusalem. With a Preface, Notcs, and the complete Correspondence. By the Chcvalier C. C. J. Bunsen, Ph.D., D.C.L. Translated under the superintendence of and with additions by the Author. Post 8vo.9s. 6d. cloth.

\section{BUNSEN.-EGYPT'S PLACE IN 'UNIVERSAL HISTORY:}

An Historical Investigation, in Five Books. By C.C.J.Bunsen, D. Ph. and D.C.L. Translated from the German, by C. H. Cottrell, Ks sq. M.A. Vol. I. containing the First Book, or Sources and Primeval Facts of Egyptian History: with an Egyptian Grammar and Dictionary, and a complete List of Hicroglyphical Signs; an Appendix of Authoritics, embracing the complete Text of Manetho and Eratosthenes, Fgyptiaca from Pliny, Strabr, etc.; and Plates representing the Egyptian Divinitics. 8vo. with uumerous Illustrations, 28s. cloth.

\section{BURDER.-ORIENTAL CUSTOMS,}

Applied to the Illustration of the Sacred Scriptures. By Dr. Samuel Burder. Ncw Edition, with Additions. Frolscap 8vo. 8s. 6d. clotl. 


\section{BURNS. - THE PRINCIPLES OF CHRISTIAN PHILOSOPHY;}

Containing the Doctrines, Duties, Admonitions, and Consolations of the Christian Religion. By John Burns, M.D.F.R.S. 6th Edition. Foolscap 8vo. 6s.6d. cloth.

\section{BURNS.-CHRISTIAN FRAGMENTS ;}

Or, Remarks on the Nature, Precepts, and Comforts of Religion. ByJohn Burns, M.D.

F.R.S. Foolscap 8vo. 5s. cloth.

\section{BUTLER.-A SKETCH OF MODERN AND ANCIENT GEOGRAPHY.}

By Samuel Butler, D.D., late Lord Bishop of Lichfield and Coventry; and formerly Head Master of Shrewsbury School. New Edition, revised by the Author's Son. 8vo.9s. boards.

\section{BUTLER.-AN ATLAS OF MODERN GEOGRAPHY.}

Consisting of Twenty-three coloured Maps, from a New Set of Plates; with an Index of all the Names of Places, referring to the Latitudes and Longitudes. By the late Dr. Butler, Bishop of Lichfield. New Edition, corrected. 8vo.12s.half-bound.

\section{BUTLER.-AN ATLAS OF ANCIENT GEOGRAPHY.}

Consisting of Twenty-three coloured Maps : with an Index of all the Names of Places, referring to the Latitudes and Longitudes. By the late Dr. Butler, Bishop of Lichfield. New Edition, corrected. 8 vo. 128, half-bound.

BUTLER - - A GENERAL ATLAS OF MODERN AND ANCIENT GEOGRAPHY. Consisting of Forty-five coloured Maps, and copic us $I$ ndices referring to the Latitudes alld Longitudes. By the late Dr. Butler, Bishop of Lichfield. New Edition, from an entirely new and corrected set of Plates. 4to.24s. half-b und.

\section{CABINET LAWYER (THE).}

A Popular Digest of the Laws of England, Civil and Criminal; with a Dictionary of Law Terms, Maxims, Statutcs, and Judicial Antiquities; Correct Tables of Assessed Taxes, Stamp Duties, F.xcise Licences, and Post-Horse Duties; Post-Office Regulations, and Prison Discipline. Fourteenth Edition. enlarged, and corrected throughont, with the Legal Decisions and Statutes to Michaelmas 'Term, 10 and 11 Victoria. Fcap. 8vo. 10s.6d. cloth.

CALLCOTT. --HOME AMONG STRANGERS :

A Tale. By Maria Hutchins Callcott. 2 vols. fcap. Svo.9s. cloth.

\section{CALLCOTT. - A SCRIPTURE HERBAL:}

With upwards of 120 Wood Engravings. By Lady Callcott. Square crown 8vo. 17.5s. cloth.

\section{CAREY.-THE PAST, THE PRESENT, AND THE FUTURE.} By H.C.Carey, author of "The Priuciples of Political Economy," etc. Svo. 10s.6d. cloth.

\section{CARTOONS. - THE PRIZE CARTOONS EXHIBITED IN WESTMINSTER -} HALI, Published under the Sanction and Patronage of Her Majesty's Commissioners on the Fine Arts. Eleven large folio Engravings, in a neat Portfolio, 57.5s.; Proofs before letters, 81.88 .

\section{CATLOW.-POPULAR CONCHOLOGY;}

Or, the Shcll Cabinet arranged : being an Introduction to the modern System of Conchology; with a sketch of the Natural History of the Animals, an account of the Formation of the Shells, and a complete lescriptive List of the Families and Genera. By Agues Catlow. Foolscap 8vo. with 312 Woodcuts, $10 s .6 d$. cloth.

\section{CHALENOR.-WALTER GRAY,}

A Ballad, and other Poems. By Mary Chalenor. $2 \mathrm{~d}$ Edition, with Additions, including the Author's Poetical Remains. Fcap. 8 vo.6s, cloth.

\section{THE CLOSING SCENE;}

Or, Christianity and Infidelity contrasted in the Last Hours of Remarkable Persons. By the Author of "The Bishop's Daughter," "Self-Sacrifice," "The Life-Book of a Labourer," etc. Fcap. Svo.6s. cloth.

COCKS (C.)-BORDEAUX, ITS WINES, AND THE CLARET COUNTRY. By C. Cocks, B.l.., Professor of thc Living Languages in the Royal Colleges of France; Translator of the Works of Michelet, Mignet, and Quinet. Post 8vo.8s. 6d. cloth.

COLLEGIAN'S GUIDE (THE);

Or, Recollections of College Days; setting forth the Advantages and Temptations of a University Hducation. By the Rev. Janes Pycroft, M.A. Post Sro.10s.6d. cloth. 
COLLIER ( $J$. PAYNE.)-A BOOK OF ROXBURGHE BALLADS.

Edited by John Payne Collier, Esq. Feap. 4to. with Woodeuts, 21s. boards; morocco, 38 s.

\section{COLTON - LACON; OR, MANY THINGS IN FEW WORDS.}

By the Rev.C.C. Colton, New Edition. 8vo.12s.cloth.

\section{CONVERSATIONS ON BOTANY.}

New Edition, improved. Fuolscap Svo.with 22 Plates, 7s.6a.cloth; with eoloured Plates, 12 s.

\section{CONVERSATIONS ON MINERALOGY.}

With Plates, engraved by Mr. and Mrs. Lowry, from Original Drawings. Third Edition, enlarged, 2 vols, foolscap 8vo. 14s, cloth.

CONYBEARE AND HOWSON.-THE LIFE AND LETTERS OF ST. PAUL; comprising a complete Biograply of the Apostle, and a Paraphrastic Translation of his Epistles inserted in Chronological order. Edited by the Rev. W. J. Conybeare, M.A. late Fellow of Trinity College, Cambridge; and the Rev.J.S. Howson, M.A. Principal of the Collegiate Institution, Liverpool. 4to, richly illustrated by Maps, Views, Engravings of Coins, etc.

[In the press.

\section{COOPER (THE REV. E.)-PRACTICAL AND FAMILIAR SERMONS,}

Designed for Parochial and Domestic Instruction. By the Rev. Edward Cooper. New Editions. 7 vols. $12 \mathrm{mo} .1 \mathrm{l} .18 \mathrm{~s}$. boards .

COOPER (THE REV. E.)-SERMONS,

Chief y designed to elucidate some of the leading Doctrines of the Gospel. By the Rev. Edward Cooper. New Edition. 2 vols. 12mo. 10s. boards.

\section{COPLAND.-A DICTIONARY OF PRACTICAL MEDICINE;}

Comprising General Pathology, the Nature and Treatment of Diseases, Morbid Structures, and the Disorders especially incidental to Climates, to Sex, and to the different Epochs of Life, with numerous approved Formulæ of the Medicines recomnended. By James Copland, M.D., etc.etc. Vols.I. and II., 8vo.3l. cloth; and Parts X. to XIII. 4s.6d. each.

\section{COQUEREL.-CHRISTIANITY;}

Its perfect adaptation to the Mental, Moral, and Spiritual Nature of Man. By Athanase Coquerel, one of the Pastors of the French Protestant Church in Paris. Translated by the Rev.D. Davison, M.A. With an Introductory Notice of the State of the Protestant Church of France, written by the Author for the Finglish Edition. Post 8vo. 12s. cloth.

\section{COSTELLO (MISS). - THE ROSE GARDEN OF PERSIA.}

A Series of Translations from the Persian Poets. By Louisa Stuart Costello, author of "Specimens of the Early Poetry of France," etc. Long 8vo. with 12 Illuminated Titles, and Borders printed in Colours, 18s. boards; or 31s.6d. morocco.

\section{COSTELLO (MISS).FALLS, LAKES, AND MOUNTAINS OF NORTH} WALES; being a Pictorial Tour through the most interesting parts of the Country. By Louisa Stuart Costello, author of "The Rose Garden of Persia," etc. Profusely illustrated with Views, from Original Sketches by D. H. M'Kewan, engraved on wood, und lithographed, by T. and E. Gilks. Square 8vo, with Map, 14s. cloth.

COULTER.-ADVENTURES ON THE WESTERN COAST OF SOUTH AMERICA AND IN THE INTR.RIOR OF CALIFORNIA. Including a Narrative of incidents at the Kingsmill Islands, New Ireland, New Britain, New Guinea, and other Islands in the Pacific Ocean. With an Account of the Natural Productions, and the Manners and Customs, in Peace and War, of the various savage Tribes visited. By Johil Coulter, M.D. author of "Adrentures in the Pacific." 2 vols, post 8 vo.16s. cloth.

\section{COULTER.-ADVENTURES IN THE PACIFIC;}

With Observations on the Natural Productions, Manners and Customs of the Natives of the various Islands; Remarks on the Missionaries, British and other Residents, etc. By John Coulter, M.D. Post 8vo.7s.6d. cloth.

\section{COULTON-AN INQUIRY INTO THE AUTHORSHIP OF THE LETTERS} OF JUNIUS. By David Trevena Coulton. 4to.

[In November.

CRESY (E.)-AN ENCYCLOPAEDIA OF CIVIL ENGINEERING, HISTORICAL, THEORETICAL, and PRAC'TICAL. By Edward Cresy, F.S.A. C.E. Illustrated by upwards of Three Thousand Engravings on Wood, explunatory of the Principles, Muchinery, and Constructions which come under the Direction of the Civil Enginecr. One large Volume 8 vo. upwards of 1,600 pages, $3 l$. 13s. $6 d$. clotl. 


\section{CROCKER'S ELEMENTS OF LAND SURVEYING.}

Fifth Edition, corrected throughout, and considerably improved and modernised, by T. G. Bunt, Land Survcyor, Bristol. To which are added, TABLES OF SIX-FIGURE LOGARITHMS, etc., superintended by Richard Farley, of the Nautical Almanac Establish. ment. Post 8vo. 12s. cloth.

\section{D'AGINCOURT.-THE HISTORY OF ART,}

By its Monuments, from its Decline in the Fourth Century to its Restoration in the Sixteenth. Translated from the French of Seroux D'Agincourt, by Owen Jones, architect. With 3,335 Subjects, engraved on 328 Plates. Vol. I. Architecture, 73 plates; vol. II. Sculpture, 51 plates; vol. III. Painting, 204 plates. 3 rols.royal folio, $5 l .5 s$. sewed.

DALE (THE REV. THOMAS). - THE DOMESTIC LITURGY AND FAMILY CHAPLAIN, in Two Parts: the First Part bcing Church Services adapted for Domestic Use, with Prayers for every Day of the Week, sclected exclusively from the Book of Common Prayer. Part II. comprising an appropriate Sermon for every Sunday in the Ycar. By the Rev. Thomas Dale, M.A. Vicar of St. Pancras. Post 4to. 2ls. cloth: or, bound by Hayday, 31 s. $6 d$. calf lettered; 50 s. morocco.

DAVY (SIR HUMPHRY),-ELEMENTS OF A GRICULTURAL CHEMISTRY in a Course of Lectures. By Sir Humphry Davy. With Notes by Dr. John Dary. New Edition. 8vo. with 10 Plates, 15s. cloth.

DE JAENISCH AND WALKER.-DE JAENISCH'S CHESS PRECEPTOR: A New Analysis of the Openings of Games. By C. F. De Jaenisch, of St. Petersburgh. Translated from the French, with copious Notes, by G. Walker, author of "Chess Studies," and various otlier Works on the Game of Chess. 8vo.15s. cluth.

DE LA BECHE.-REPORT ON THE GEOLOGY OF CORNWALL, DEVON, AND WEST SOMERSET. By Henry T. De la Beche, F.R.S. etc., Director of the Ordnance Geological Survey. Published by Order of the Lords Commissioners of H.M. Treasury. 8 vo. with Maps, Woodcuts, and 12 large Plates, 14s.cloth.

DE LA GRAVIERE.-SKETCHES OF THE LAST NAVAL WAR.

Translated from the French of Captain E. Jurien de la Gravière, with an Introduction, and Explanatory Notes. By the Hon. Captain Plmkett, R. N., author of "Tlie Past and Future of the British Navy." 2 vols. post 8 vo. with Plans, 18s, cloth.

DE STRZELECKI (P.E.)-PHYSICAL DESCRIPTION OF NEW SOUTH WALES AND VAN DIEMAN'S LAND. Accompanied by a Geological Map, Sections, and Diagrams, and Figures of the Organic Remains. By P. E. De Strzelecki. Svo. with coloured Map and numerous Plates, 24s. cloth.

\section{DIBDIN (THE REV. T. F.)-THE SUNDAY LIBRARY:}

Containing nearly One hundred Sermons by eminent Divines. With Notes, etc. by the Rev. T.F.Dibdin, D.D. 6 vols. foolscup 8vo. with 6 Portraits, 30s, cloth; neatly half-bound in morocco, with gilt edges, $2 l .12 s .6 d$.

\section{DISCIPLINE.}

By thc Author of "Letters to my Unknown Friends," "Twelve Years Ago," and "Some Passages from Modern History." $18 \mathrm{mo.2s.} \mathrm{cloth.}$

DOUBLEDAY AND HEWITSON'S BUTTERFLIES. - THE GENERA OF DIURNAL LEPIDOPTERA; comprising their Generic Characters-a Notice of the Habits and Transformations-and a Catalogue of the Species of each Genus. By Edward Doubleday, Esq. F.L.S.etc., Assistant in the Zoological Department of the British Museum. Iñperial 4to. uniform with Gray and Mitchell's Ornithology; illustrated with 75 coloured Plates, by W. C. Hewitson, Esq. Author of "British Oology."

** Publishing in Monthly Parts, 5s. each; each Part consisting of two coloured Plates, with accompanying Letter-press. To be completed in not exceeding 40 Parts, 22 of which are now ready.

DRESDEN GALLERY.-THE MOST CELEBRATED PICTURES OF THE ROYAL GALLERY at DRESDEN, drawn on Stone, from the Originals, by Franz Hanfstaengel : with Descriptive and Biographical Noticcs, in French and German. Nos. I. to LII., imperial folio, each containing 3 Plates with accompanying Letter-press, price $20 s$.'to Subscribers; to Non.subscribers, 30s. Single Plates, I2s. each.

* To be cumpleted in 8 tnore numbers, price 20s. each. to Subscribers; Nos. LI. to LX. containing each 4 Plates and Letterpress.

\section{DUNLOP.-TRAVELS IN CENTRAL AMERICA.}

With a Journal of nearly Three Years' Residence in the Country. To which are added, a Sketch of thc History of the Republic, and an Account of its Climate, Productions, Commerce, etc. By Robert Glasgow Dunlop, Esq. Post 8vo. with Map, I0s.6d. cloth. 


\section{DUNLOP (JOHN).--THE HISTORY OF FICTION:}

Being a Critical Account of the most celebrated Prose Works of Fiction, from the earliest Greek Romances to the Novels of the Present Age. By John Dunlop. New Editiou, complete in One Volume. Medium Svo. 15s. cloth.

\section{EASTLAKE.-MATERIALS FOR A HISTORY OF OIL PAINTING.}

By Clurles Lock Eastlake, Esq. R.A. F.R.S. F.S.A. Secretary to the Royal Commission for Promoting the Fine Arts in connexion with the rebuilding of the Houses of Parliament, etc. 8vo. 16s. cloth.

\section{ECCLESTON (JAMES).-AN INTRODUCTION TO ENCLISH ANTIOUITIES.} Intended as a Companion to the History of England. By James Eccleston, B.A. Head Master of Sutton Coldfield Grammar School. 8vo. with numerous Engravings on Wood, 218. cloth.

\section{ELLIOTSON.-HUMAN PHYSIOLOGY:}

With which is incorporated much of the Elementary Part of the "Institutiones Physiologica" of J.F. Blumenbach, Professor in the University of Gottingen. By John Elliotson, M.D. Cautab. F.R.S. Fifth Edition, 8vo. with numerous Woodcuts, 2l.2s. cloth.

THE ENGLISHMAN'S GREEK CONCORDANCE OF THE NEW TESTAMENT; being an attempt at a Verbal Connexion between the Greek and the English Texts; including a Concordance to the Proper Names, with Indexes, Greek-English aud English.Greek. 2d Edition, carefully revised, with a new Index, Greek and English. Royal 8vo. $42 s$.

THE ENGLISHMAN'S HEBREW AND CHALDEE CONCORDANCE OF THE OLD TESTAMENT; being an attempt at a Verbal Connexion between the Original and the English Translations: with Indexes, a list of the Proper Names and their occurrences, etc.etc. 2 vels. royal $8 v 0.3 l .13 s .6 d$. cloth; large paper, $4 l .14 s .6 d$.

EPHEMERA.-A HAND-BOOK OF ANGLING;

Tcaching Fly Fishing, Trolliug, Bot tom Fishing, and Salmon Fishing. With the Natural History of River Fish, and the best Modes of Catching them. By Ephemera (of Bell's Life in London). New Edition. Foolscap 8vo. with Wood Engravings, 9s. cloth.

ERMAN.-TRAVELS IN SIBERIA:

Including Excursions Northwards, down the Obi, to the Polar Circle, and Southwards, to the Chinese Frontier. By Adolph Erman. Translated by W. D. Cooley, Esq. author of "The History of Maritime and Inland Discovery;" translator and editor of Dr. Parrot's "Journey to Ararat," etc. 2 vols. 8 vo. with Map, 31s.6d. cloth.

EVANS.-THE SUGAR PLANTER'S MANUAL;

Being a Treatise on the Art of obtaining Sugar from the Sugar Cane. ByW.J.Evans, M.D. 8 vo. 9 s. cloth.

\section{FAREY.-TREATISE ON THE STEAM-ENGINE,}

Historical, Practical, and Descriptive. By John Farey, Engineer. 4to. illustrated by numerous Woodcuts, and 25 Copper-plates, $52.5 \mathrm{~s}$ in boards.

\section{FIELD.--PRISON DISCIPLINE;}

And the Advantages of the Separate System of Imprisonment: with a detailed Account of the Discipline now pursued in the New County Gaol at Reading. By the Rev.J. Ficld, M.A. Chaplain. New Edition. 2 vols. 8vo.20s. cloth.

\section{FLOWERS AND THEIR KINDRED THOUGHTS;}

A Scries of Stanzas-On Hope, Innocence, Modesty, Childhood, Humility, Joy, Love, Constancy, Fascination, Timidity, Fine Taste, Thoughts, Recollection, and Friendslip. By Mary Anne Bacon. Illustrated by the Snowdrop, Primrose, Violet, Harebell and Pimpernel, Lily of the Valley, Haw thorn, Rose, Hon eysuckle, Caruation, Convolvulus, Fuchsia, Pansy, Forget-me-not, and Holly; designed and printcd in Colours by Owen Jones. Imperial Svo. 3 Is.6d. elegantly bound.

FORSTER (REV.C.)-THE HISTORICAL GEOGRAPHY OF ARABIA; Or, the Patriarchal Evidences of Revealed Religion. A Memoir, with Illustrative Maps and an Appendix, containing Translations, with an Alphabet and Glossary of the Hamyaritic Inscriptions recently discovered in Hadramaut. By the Rev. Charles Forster, B.D., Rector of Stisted, Essex; author of "Mahometanism Unveiled." 2 vols. 8vo. 30s. clotll.

FORSTER (REV. C.)-THE LIFE OF JOHN JEBB, D.D. F.R.S.

Late Bishop of Limerick. With a Selection from his Letters. By the Rev. Charles Forster, B.D., Rector of Stisted, Essex, and one of the Six Preachers in thc Cathedral of Christ, Canterbury, formerly Domestic Chaplain to the Bishop. Ncw Edition. 8vo. with Portrait, etc. 16s. cloth. 


\title{
FOSTER.-THE HAND-BOOK OF EUROPEAN LITERATURE.
}

\author{
By Mrs. Foster. Foolscap 8vo. \\ [In the press.
}

\section{FRESENIUS.-A MANUAL OF AGRICULTURAL CHEMISTRY.}

By Dr. C.R. Fresenius, Professor of Chemistry and Natural Philosophy, Wiesbaden ; late Assistant in the Laboratory of Giessen. Translated from the Germall. [In the press.

FROM OXFORD TO ROME : AND, HOW IT FARED WITH SOME WHO LATELY MADE THE JOURNEY. By a Companion Traveller. New Edition, revised and corrected. Fcp.8vo. with Frontispiece, 6s. cloth.

\section{GARDINER.-SIGHTS IN ITALY:}

With some Account of the Present State of Music and the Sister Arts in that Country. By William Gardiner, author of "Sacrcd Melodies," etc.; Member of the Academy of St. Cecilia, Rome; and of the Class of Fine Arts of the Institut Historique of France. 8vo. with engraved Music, 16s, cloth.

\section{GERTRUDE.}

A Tale. By the author of "Amy Herbert." Edited by the Rev. William Sewell, B.D., of Exeter College, Oxford. New Edition. 2 vols. foolscap 8vo. 9s. cloth.

GIBBON.-HISTORY OF THE DECLINE AND FALL OF THE ROMAN EMPIRE. A new Edition. in One Volume; with an Account of the Author's Life and Writings, by Alexander Chalmers, Esq. F.A.S. 8vo. with Portrait, 18s. cloth.

* An Edition in 8 vols. $8 v 0.60 s$. boards.

\section{GOLDSMITH-THE POETICAL WORKS OF OLIVER COLDSMITH.}

Illustrated by Wood Engravings, from Designs by Members of the Etching Club. Edited by Bolton Corney, Esq. Square crown 8v0., uniform with "Thomson's Seasons," 21 s. cloth; or $36 s$. bound in morocco, by Hayday.

GOWER.--THE SCIENTIFIC PHENOMENA OF DOMESTIC LIFE FAMILIARLY EXPLAINED. By Charles Foote Gower. New Edition. Foolscap 8vo, with Engravings on Wood, $5 s$. cloth.

\section{GRAHAM.-ENGLISH; OR, THE ART OF COMPOSITION}

explained in a Series of Instructions aud Examples. By G. F. Graham. New Edition, revised and improved. Fuolscap 8vo. 68. cloth.

\section{GRANT (MRS.)-LETTERS FROM THE MOUNTAINS.}

Being the Correspondence with her Friends, between the years 1773 and 1803. By Mrs. Grant, of Laggan. 6th Edition. Edited, with Notes and Additions, by her Son, J. P. Grant, Esq. 2 vols, post 8 vo. 21 s, cloth.

GRANT (MRS., OF LAGGAN). - MEMOIR AND CORRESPONDENCE of the late Mrs. Grant, of Laygan, author of "Letters from the Mountains," etc. F.dited by her Son, J. P. Grant, Esq. New Edition. 3 vols. post 8vo. Purtrait, 1l. 11s.6d. clotl.

\section{GRAY (THOMAS).-GRAY'S ELEGY,}

Written in a Country Churchyard. Illuminated in the Missal style. By Owen Jones, Architect. Imp. 8vo.31s.6d. elegantly bound.

GRAY AND MITCHELL'S ORNITHOLOGY.-THE GENERA OF BIRDS;

Comprising their Generic Characters, a Notice of the Habits of each Genus, and an extensive List of species, referred to their several Genera. By George Robert Gray, Acad. Imp. Georg. Florent. Soc. Corresp. Senior Assistant of the Zoological Department, British Museum: and author of the "List of the Genera of Birds," etc. Imperial 4to, illustrated with 350 Plates, by David William Mitchell, B.A.

" "In course of publication in Monthly Parts, 10s.6d, each; each Part consisting of Four coloured Plates and Three plain, with Letter-press. The Work will not eaceed 50 Monthly Parts, of which 48 have appeared.

Order I.--Accipitres has been completed, and may be had separately. Imperial Sro. with 15 coloured and 12 plain Plates, 27.8 s. boards.

GRIMBLOT (P.)-LETTERS OF WILLIAM III. AND LOUIS XIV. AND OF THEIR MINISTERS. Illustrating the Domestic and Foreign Policy of England during the period which followed the Rcvolution of 1688 . Extracted from the Archives of France and England, and from Family Papers. Edited by P. Grimblot. 2 vols. 8vo. 30s. cloth.

* Amongst other important and interesting subjects, this work contains the whole of the diplumatic correspondence relative to the Spanish succession, etc. (1697-1702). 


\section{GWILT.-AN ENCYCLOPADIA OF ARCHITECTURE;}

Historical, Theoretical, and Practical. By Joseph Gwilt, Esq., F.S.A. Illustrated with upwards of 1,000 Engravings on Wood, from Designs by J.S. Gwilt. 8vo.2l. 12s.6d. cloth.

\section{HALL, - MIDSUMMER EVE:}

A Fairy Tale of Love. By Mrs. S. C. Hall. Square crown 8vo, with nearly 300 Wood F.ngravings, 21s. cloth, gilt edges.

* * The Illustrations from Designs by D. Mraclise, C. Stanfield, T. Creswick, E. M. Ward, A. Elmore, W. E. Frost, J. N.Paton, F. Goodall, T. Lardseer, E. H. Wehnert, K. Huskisson, F. W. Tophain, K. Meadows, F. W. Fuirholt, J. Franklin, J. H. Weir, F. W. Huline, J. Lecurieux, and T. $R$. Hacquoid; engraved by Green, Dalziel, Bastin, Linton, etc.

\section{HALL'S (SIDNEY) GENERAL LARGE LIBRARY ATLAS OF FIFTY-}

THREE MAPS (size 20 in by 76 in.), with the Divisions and Boundaries carefully coloured; and an Alphabetical Index of all the Names contained in the Maps, with their Latitude and Longitude. An entirely New Edition, corrected throughout from the best and most recent Authorities; with all the Railways laid down, and many of the Maps re-drawn and re-eng raved.

**** Publishing in Monthly Parts, of which 11 hnve appeared. To be completed in 14 Parts, price $6 s$. each.

\section{HALSTED.-LIFE AND TIMES OF RICHARD THE THIRD,}

as Duke of Gloucester and King of England: in which all the Charges against him are carefully investigated and compared with the Statements of contemporary Authorities. By Caroline A. Halsted. 2vols.8vo.with Portrait and other Illustrations, 1l. 10s, cloth.

\section{HARRIS.-THE HIGHLANDS OF FETHIOPIA;}

Being the Account of Eighteen Months' Residence of a British Embassy to the Christian Court of Shoa. By Major Sir W..C. HIarris, author of "Wild Sports in Southern Africa," etc. New Edition. 3 vols. 8 vo.with Map and Illustrations, 2l. 2s. cloth.

HARRISON.-ON THE RISE, PROGRESS, AND PRESENT STRUCTURE OF THE ENGLISH LANGUAGE. By the Rev. M. Harrison, M.A., late Fellow of Queen's College, Oxford. Post Svo.

[In the press.

\section{HAWBUCK GRANGE;}

Or, the Sporting Adventures of Thomas Scott, Esq; By the Author of " $\because$ Handley Cross ; or the Spa Hunt," "Jorrochs' Jaunts and Jollitics;" etc. 8vo. with eight 111 ustrations, by Phiz, 12s. cloth.

\section{HAWKER.-INSTRUCTIONS TO YOUNG SPORTSMEN}

In all that relates to Guns and Shroting. By Lieut. Col. P. Hawker. 9th edition, corrected, enlarged, and improved, with Eighty-five Plates and Woodeuts, by Adlard and Branston, from Drawings by C. Varley, Dicks, etc. Svo. $21 s$. cloth.

\section{HAYDON.-THE AUTOBIOGRAPHY AND JOURNALS OF THE LATE}

B. R. HAYDON, Historical Painter.

In preparation.

\section{HAYDON (B. R.)-LECTURES ON PAINTING AND DESIGN,}

Delivered at the Iondon Institution, the Royal Institution, Albermarle Street, to the University of Oxford, etc. By B. R. Haydon, Historical Painter. 2 vols. 8vo. with Protraits of the Aluthor and Sir David Wilkie, and numerous otber Illustratiuns, 24s. cloth.

\section{HINTS ON ETIQUETTE AND THE USAGES OF SOGIETY:}

With a Glance at Bad Habits. By Ayorós. "Manuers make the Man." New Edition, revised (with udditions) by a Lady of Rank. Foolscap 8v0.2s.6d. cloth.

\section{HISTORICAL CHARADES.}

By the Author of "Lctters frum Madras," Foolscap 8vo. 5s. cloth.

\section{HISTORICAL PICTURES OF THE MIDDLE ACES,}

In Black and White. Made on the spot, from Records 11 the Archives of Switzerland. By a Wandering Artist. 2 vols. post 8 vo. 18s. cloth.

HOARE-A DESCRIPTIVE ACCOUNT OF A NEW METHOD OF PLAN'TING AND MANAGING THE ROOTS OF GRAPE, VINFS. By Clement Hoare, author of "A Treatise on the Cultivation of the Grape Vine on Open Walls." $12 \mathrm{mo} .58 . \mathrm{cl}$." 
HOARE-A PRACTICAL TREATISE ON THE CULTIVATION OF THE GRAPE VINE ON OPEN WALLS. By Clement Hoare. New Edition. 8vo.78.6d. cloth.

\section{HOBBES.-THE COMPLETE WORKS OF THOMAS HOBBES,}

Of Malmesbury; now first collected, and edited by Sir William Molesworth, Bart. 16 vols. 8 vo. 8l. cloth.

"* Separately, the English Works, in 11 vols. 5l.10s.; the Latin Works, in 5 vols. 2l.10s.

\section{HOLLAND.-MEDICAL NOTES AND REFLECTIONS.}

By Henry Holland, M.D.F.R.S. etc. Fellow of the Royal College of Physicians, Physician Extraordinary to the Queen, and Physician in Ordinary to His RoyalHighness Prince Albert. New Edition. 8vo. 18s. cloth.

HOOK (DR. W. F.)-THE LAST DAYS OF OUR LORD'S MINISTRY; A Course of Lectures on the principal Events of Passion Week. By IValter Farquhar Hood, D.D., Vicar of Leeds, Prebendary of Lincoln, and Chaplain in Ordinary to the Queen. New Edition. Foolscap 8vo. 6s. cloth.

\section{HOOKER.-KEW GARDENS ;}

Or a Popular Guide to the Royal Botanic Gardens of Kew. By Sir William Jackson Hooker, K.H.D.C.L. F.R.A. \& L.S. etc. etc. Director. New Edition. 16mo. with numerous Wuod Engravings, $6 d$. sewed.

\section{HOOKER.-THE BRITISH FLORA.}

Comprising the Phænogamous or Flowering Plants, and the Ferns. By Sir William Jackson Hooker, K.H. LL.D. F.R.A. and L.S. etc. ete. etc. New Edition, with Additions and Corrections; and 173 Figures, illustrative of the Umbelliferous Plants, the Composite Plants, the Grasses, and the Ferns. Vol.1. Svo., with 12 Plates, 14s. plain; with the Plates coloured, 24s. cloth.

Vol.II.in Two Parts, comprising the Cryptogarnia and the Fungi, completing the British Flora, and forming Vol. V., Parts 1 and 2, of Smith's English Flora, 24s. boards.

HORNE (THE REV. T. H.) - AN INTRODUCTION TO THE CRITICAL STUDY AND KNOWLEDGE OF THE HOLY SCRIPTUR;S. By the Rev. Thomas Hartwell Horne, B.D. of St.John's Collegc, Cambridge. New Edition, revised and corrected. 5 vols. 8vo. with Maps and Fac-similes, $3 l .3 s$. cloth; or $5 l$. bound in calf by Hayday.

HORNE (THE REV. T. H.)-A COMPENDIOUS INTRODUCTION TO THE STUDY OF THE BIBI,E. By the Rev. Thomas Hartwell Horne, B.D. of St. John's College, Cambridge. Being an Analysis of his "Introduction to the Critical Study and Knowledge of the Holy Scriptures." New Edition. 12mo. with Maps and Engravings, 9s. boards.

\section{HOWITT, (MARY).-BALLADS AND OTHER POEMS.}

By Mary Howitt. Square crown 8vo. with a Portrait from a Picture by Miss Gillies, beautifally engraved by W. H. Egleton, 18s. cloth; morocco, 368. (bound by Hayday).

\section{HOWITT.-THE CHILDREN'S YEAR.}

By Mary Howitt. With Four Illustrations, engraved by John Absolon, from Original Designs by Anma Mary Howitt. Square 16mo.5s, cloth.

\section{HOWITT. - THE BOY'S COUNTRY BOOK:}

Being the real Life of a Country Boy, written by Himself; exhibiting all the Amusements, Pleasures, and Pursuits of Children in the Country. Edited by William Howitt, autlior of "The Rural Life of Eingland," etc. New Edition. Fcap. 8vo. with 40 Woodcuts, 6s. cloth.

\section{HOWITT.-VISITS TO REMARKABLE PLACES;}

Old Halls, Battle-Fields, and Sccnes illustrative of Striking Passages in English History and Poctry. By William Howitt. New Edition. Medium 8vo. with 40 Illustrations, 21s. clotl.

SECOND SERIES, chiefy in the Counties of DURHAM and NORTHUMBERLAND, with a Stroll along the BORDER. Medium 8vo. with upwards of 40 highly-fillished Woodcuts, from Drawings made on the spot, 21s. cloth. 


\section{HOWITT.-THE RURAL LIFE OF ENGLAND.}

By William Howitt. New Edition, corrected and revised. Medium 8vo, with Engravings on Wood by Bewick and Williams, uniform with "Visits to Remarkable Places," 21s. cloth.

\section{HOWITT.-THE RURAL AND DOMESTIC LIFE OF GERMANY:}

With Characteristic Sketches of its chief Cities and Scenery. Collected in a General Tour, and during a Residence in that Country in the Years 1S40-42. By William Howitt, author of "The Rural Life of England," etc. Medium 8ro., with above 50 Illustrations, 21s. cloth.

\section{HOWITT.-THE STUDENT-LIFE OF GERMANY.}

From the Unpublished MS. of Dr. Cornelius. By William Howitt. 8ro. with 24 Wood Engravings, and 7 Steel Plates, 21s. cloth.

\section{HOWITT.-COLONISATION AND CHRISTIANITY:}

A Popular History of the Treatment of the Natives, in all their Colonies, by the Europeaus. By William Howitt. Post 8vo.10s.6d. cloth.

\section{HUDSON.-PLAIN DIRECTIONS FOR MAKING WILLS}

In conformity with the Law, and particularly with reference to the Act $7 \mathrm{Wm}$. IV. and 1 Vict. c. 26. To which is added, a clear Exposition of the Law relating to the Distribution of Personal Estate in the case of Intestacy, witl two Forms of Wills, and much useful Information, etc. By J.C.Hudson, Esq. New Edition, corrected. Fcap.8ro.2s.6a. cloth.

\section{HUDSON.-THE EXECUTOR'S GUIDE.}

By J. C. Hudson, Esq., of the Legacy Duty Office, London: author of "Plain Directions for Making Wills," aud "The Parent's Hand-Book." New Edition. Foolscap 8vo.5s.cloth.

* The above two works may be had in One volume, price 7s. cloth.

\section{HUMBOLDT (BARON). - COSMOS :}

A Sketch of a Pliysical Description of the Univcrsc. Translated, with the Autbor's sanction aud co-operation, under the superintendence of Lieuteuant-Colonel Edward Sabine, F.R.S. For. Sec. R.S. New Edition. Vols.I. and II.post 8vo. 12s, each, eloth.

"Je vous antorise, Monsienr, de vous servir en tonte nccnsion de la décluration, que in belle traduction du Colonel Sabine, enriche de rectifications et de notes très-précienses, et qui ort toute mon approbution, est la spule par liquelle j"ri vivement desiré voir introduit mon ouvrage dans la littérature de votre pays."-Baron Humboldt to Mr. Murray.

\section{HUME.-THE LEARNED SOCIETIES AND PRINTING CLUBS OF THE}

UNITED KINGDOM; being an Account of their respective Origin, History, Objects, and Constitution: full details respecting Membership, Fees, thcir published Works and Transactions, Notices of their Periods and Places of Mceting, etc. With a general Introductiun, and a Classified Index. Compiled from Official Documents, by the Rev. A. Hume, LL.D., F.S.A. Post 8 vo. 8s.6d. cloth.

\section{HUNT.-RESEARCHES ON LICHT:}

An Examination of all the Phenomcna connected with the Chemical and Molecular Changes produccd by the Influencc of the Solar Rays: embracing all the known Photographic: Processes, and new Discoveries in the Art. By Robert Hunt, Kceper of Mining Records, Museum of Economic Geology. 8vo. with Plate and Woodcuts, 10s.6d.cloth.

JAMES. - A HISTORY OF THE LIFE OF EDWARD THE BLACK PRINCE, and of various Events connected therewith, which occurred during the Reign of Edward 111. King of England. By G. P. R. James, Esq. New Edition. 2 vols. foolscap 8vo. with Map, 15s.

\section{JAMESON.-SACRED AND LEGENDARY ART.}

By Mrs. Jamcson. 2 vols. square crown 8vo., illustrated by numerous Woodcuts, with a a few Fitchings by the Author.

[Nearly ready.

Vol. I. contains Legends of the Angels and Archangels, the Evangelists, the Apostlcs, the Doctors of the Church, and Mary Magdalene.

Vol. II. contains Legends of the Patron Saints, the Virgin Patroncsses, the Grcck and Latin Martyrs, the Bishops and Confessors, the Hermits, and the Warrior Saints of Christendom.

\section{JEBB (BISHOP) AND KNOX (ALEXANDER).-THIRTY YEARS' COR -}

RESPONDENCE betwcen John Jebb, I.D.F.R.S., Bishop of Limerick, Ardfert, Aghadoe, and Alexander Knox, Fisq. M.R.I.A. Fdited by the Rev. Charles Forster, B D. Rector of Stisted, formerly Domestic Chaplain to Bishop Jeb b. New Edition. 2 vols. 8vo. 28s, cloth. 


\section{JEBB.-A LITERAL TRANSLATION OF THE BOOK OF PSALMS;}

Intended to illustrate their Poetical and Moral Structure. To which are added, Dissertations on the word "Selah," and on the Authorship, Order, 'Titles, and Poetical Features of the Psalms. By the Rev. John Jebb, A.M., Rector of Peterstow. 2 vols.8vo.21s. cloth.

JEFFREY (LORD).-CONTRIBUTIONS TO THE EDINBURGH REVIEW. By Francis Jeffrey, now one of the Judges in the Court of Session in Scotland. New Edit. $3 \mathrm{vols} .8 \mathrm{vo}$. 42s. cloth.

JOHNSON.-THE WISDOM OF THE RAMBLER, ADVENTURER, AND IDLER. Consisting of 110 of the best Essays. By Samuel Juhnson, LL.D. Foolscap 8ro. 7s. cloth.

\section{JOHNSON.-THE FARMER'S ENCYCLOPÆDIA,}

And DICTIONARY of RURAL AFFAIRS : embracing all the recent Discoveries in Agricultural Chemistry; adapted to the comprehension of unscientific Readers. By Cuthbert W. Johusoll, Esq., F.R.S. Barrister-at.Law, Editor of the "Farmers' Almanack," etc. 8 vo. with Wood Engravings, $2 l$. 10s. cloth.

JONES'S GUIDE TO NORWAY, AND SALMON-FISHER'S POCKET COMPANION; founded on Experience collected in the Country. Fidited by Frederic Tolfrey, Esq., author of "'The Sportsman in France," and "The Sportsman in Canada." Foolscap 8vo. with Frontispiece and Vignette Title, and Fingravings of the proper Flies, beautifully coloured, in exact initation of the originals, 15s. cloth.

KINDERSLEY.-THE VERY JOYOUS, PLEASANT, AND REFRESHING HISTORY of the Feats, Exploits, Triumphs, and Achievements of the Good Kniyht, without Fear aud without Reproach, the gentle Lord De Bayard. Set forth in English by Edward Cocliburn Kindersley, Esq. Square post 8vo. with Ornamental Headings, and Frontispiece by E. H. Wehnert, 93.6d. cloth.

\section{KIP.-THE CHRISTMAS HOLYDAYS IN ROME.}

By the Rev. W. Ingraham Kip, M.A. Edited by the Rer. W. Sewell, B.D. Fellow and Tutor of Exeter College, Oxford. Foolscap 8vo.5s. cloth.

\section{KIRBY AND SPENCE.-AN INTRODUCTION TO ENTOMOLOGY;}

Or, Elements of the Natural History of lnsects : comprising an account of noxious and usefinl Insects, of their Metamorphoses, Food, Stratagems, Habitations, Societies, Motions, Noises, Hybernation, lnstinct, etc. By W. Kirby, M.A. F.R.S. \& L.S. Rector of Barham; and W.Spence, Esq., F.R.S. \& L.S. New Edition, enlarged. \& vols. 8vo.31s.6d. cloth.

KNOX (ALEXANDER). - REMAINS OF ALEXANDER KNOX, ESQ. Of Dublin, M.R.I.A.; containing Essays, chiefly cxplanatury, of Christian Doctrine; and Confidential Letters, with Private Papers, illustrative of the Writer's Character, Sentiments, and Life. New Edition. 4 vols. 8 vo.2l. 83 . cloth.

\section{LAING.-THE CHRONICLE OF THE KINGS OF NORWAY,}

From the Earliest Period of the History of the Nortlern Sea Kings to the Middle of the Twelfth Century: commonly called the Heimskringla. Translated from the lcelandic of Snorro Sturleson, with Notes, and a Preliminary Discourse, by Samuel Laing, Esq. 3 vols. 8vo.36s. cloth.

\section{LAING.-A TOUR IN SWEDEN}

In 1838 ; comprising Observatious on the Moral, Political,and Economical State of the Swedish Nation. By Samuel Laing, Esq. 8vo. 12s. cloth.

\section{LANE (R. I.) - LIFE AT THE WATER CURE :}

Or, a Month at Malver11. A Diary of Facts and Fancies. To which is added the Sequel. By Richard J. Lane, A.R.A. Lithographer in Ordinary to Her Majesty and His Royal Highness Prince Albert. Post 8vo. with mally lllustrations, 14s. clotli.

L. E. L.-THE POETICAL WORKS OF LETITIA ELIZABETH LANDON. New F.dition. 4 vols. foolscap 8vo. with lllustrations by Howard, etc. 28s. cloth; or bound in morocco, with gilt edges, $2 l .43$.

The following Works scparately:-

The IMPROVISATRICF - - 10s.6d. The GOLIIFN VIOIET - " $108.6 d^{\circ}$

The VENETIAN BIRACELET - 10s.6d. The TROUBADOUR - : - 108.6d. 


\section{LARDNER'S CABINET CYCLOPFEDIA;}

Being a Series of Original Works on History, Biography, Natural Pliilosophy, Natural History, Literature, the Sciences, Arts, and Manufactures. By Bishop Thirlwall, Sir James Mackintosh, Sir John Herschel, Sir Walter Scott,'Thomas Moore, Robert Southey, and other Fninent Writers. Conducted and edited by Dr. Lardner.

The Series complete in One Hundred and Thirty-three Volumes, 39l. 18s. The Works separately, $6 s$. per volume.

1. Bell's History of Russia - 3 vols. 18s.

2. Bell's Lives of British Poets 2 vols. $12 s$.

3. Brewster's Treatise on Optics 1 vol. $6 s$.

4. Cooley's History of Maritime and Inland Discovery

6. De Morgan's Treatise on Pro. babilities . . .

7. De Sismondi's History of the Italian Republics .

8. De Sismondi's Fall of the Koman Empire. .

9. Donovan's Treatise ou Chem. istry . . . 1 1 vol. $6 s$.

10. Donovan's Domestic Economy, 2 vols. $12 s$.

11. Dunham's History of Spain and Portugal. .

12. Dunham's History of Denmark, Sweden, and Nor.

way . . .

13. Dunham's History of Poland 1 vol 68

14. Dunham's History of the Germanic Empire .

15. Dunluam's History of Europe during the Middle Ages .

16. Dunham's Lives of British Dramatists

17. Dunham's Lives of Early

Writers of Great Britain . 1 vol. $6 s$.

18. Fergus's History of the United States .

19. Fosbroke's Grccian and Roman Antiquities

5 vols. $30 \mathrm{~s}$

3 vols. $18 s$

3 yols. $15 s$.

4 vols. $24 s$.

2 vols. $12 s$.

2 vols. $12 s$.

2 vols. $12 \mathrm{~s}$.

20. Forster's lives of the Statesmen of the Commonwealth 5 vols. $30 s$.

21. Forster, Mackintosh, and Courtenay's Lives of British Statesmen

7 vols. 428.

22. Gleg's Lives of Military Commanders

3 vols. $18 s$.

23. Grattan's History of the Netherlands .

24. Henslow's Treatise on Botany • • •

25. Herschel's Treatise on As. tronomy • • •

26. Herschel's Preliminary Dis course on the Study of Natural Philosophy . .

27. History of Rome . .

28. History of Switzerland.

29. Holland's Treatise on the Manufactures iu Metal.

30. James's Lives of Forcign Statesmen . . .

31. Kater and Lardner's Treatise on Mechanics.
32. Keightley's Outlines of His . tory . . . 1 1 ol. $6 s$.

33. Lardner's Treatise on Arith. metic . . 1 vol.

34. Lardner's Treat. on Geometry 1 vol.

35. Lardner's 'Treatise on Heat I vol.

36. Lardner's Treatise on Hydro. statics and Pnemmatics . 1 vol. 68.

37. Lardner and Walker's Elec. tricity and Magnetism . 2 vols, $12 s$.

3S. Mackintosh, Wallace, and Bell's History of England, 10 vols. $60 \mathrm{~s}$.

39. Montgomery and Shelley's Lives of Italian, Spanish, and Portuguese Authors . 3 vols. 188 .

40. Moore's History of Ireland . 4 vols. $24 \mathrm{~s}$.

41. Nicolas's Chronology of History . . . 1 vol. $6 s$.

42. Phillips's Treat. on Geology 2 vols. $12 s$.

43. Powell's History of Natural Philosophy

1 vol. $6 s$.

44. Porter's Treatice on the Mausufacture of Silk.

45. Porter's Treatise on the Mannfacture of Porcelain and Glass . . . .

46. Roscue's Lives of British Lawyers . .

48. Shelley's Lives of French Authors

49. Shuckard and Swainson's 'Treatise on Insects.

50. Southey's Lives of British Admirals . . .

51. Stebbing's History of the Church . . .

52. Stebbing's History of the Reformation. .

53. Swainson's Preliminary Dis. course on Natural Histury, 1 vol. $6 s$.

54. Swainson's Natural History and Classification of Animals

1 vol. $6 s$

55. Swainson's Habits and Instincts of Animals

56. Swainson's Quadrupeds . l vol. $6 s$.

57. Swainson's Birds . . . 2vols. $12 \mathrm{~s}$

58. Swainson's Fish, Reptiles, etc. . . . 2 vols. $12 s$

59. Swainson's Shells and Shellfish $\cdot$.

60. Swniuson's Animals in Menageries . . . . 1 vol. $6 s$.

61. Swainson's 'Taxidermy and Bibliography . . . 1 vol. 68 .

62. Thirlwall's History of Greece 8 vols. $48 s$. 


\section{LANETON PARSONAGE:}

A Tale for Children, on the practical use of a portion of the Church Catechism. By the author of "Amy Herbert," and "Gertrude." Edited by the Rev. W. Sewell, B.D. New

Edition. Parts I. and II. fcap.8vo. 5s. each, cloth.

\section{LATHAMI.-ON DISEASES OF THE HEART.}

lectures on Subjects connected with Clinical Medicine; comprising Discases of the Heart. By P. M. Latham, M.D. Physician Extraordinary to the Queen; and late l'hysician to St. Bartholomew's Hospital. New Edition. 2 wols. 12mo. 16s. cloth.

\section{LEE.-TAXIDERMY;}

Or, the Art of Collecting, Preparing, and Mounting Objects of Natural History. For the use of Museums and Travellers. By Mrs.R. Lee. New Edition, improved; with an account of a Visit to Walton Hall, and Mr. Waterton's Method of Preserving Animals. Fcap. 8vo. with Woodcuts, 78 .

\section{LEE.-ELEMENTS OF NATURAL HISTORY,}

For the IJse of Schools and Young Persons: comprising the Principles of Classification, interspersed with amusing and instructive Accounts of the mostremarkable Animals. By Mrs. R. Lee. 12mo. with 55 Woodcuts, 78. 6d, bound.

\section{LEMPRIERE.-A CLASSICAL DICTIONARY}

Containing a copious Account of all the Proper Names mentioned in Ancient Authors; with the Value of Coins, Weights, and Measures, used amongst the Greelis and liomans ; and a Ghronological Table. By T. Lemprièrc, D.U. New Edition, corrected. Svo. 9s. cloth.

LESLIE (C.R.)-MEMOIRS OF THE LIFE OF JOHN CONSTABLE, ESQ. R. A. Composed chiefly of his Letters. By C.1R. Leslie, R. A. Second Edition, with further Extract. from his Correspondence. Small 4to. with two Portraits (one from a new Sketch, by Mr. Leslie,) and a plate of "Spring," engraved by Lucas, 21s. cloth.

\section{LETTERS TO MY UNKNOWN FRIENDS.}

By a Lady. New Edition. Foolscap 8vo.6s.6d. cloth.

LINDLEY.-AN INTRODUCTION TO BOTANY:

By Prof.J.Lindley, Ph.D.F.R.S.I.S. etc. New Edition, with Corrections and considerable Additions. 8vo, with Six Plates and numerous Woodcuts, 1Ss. cloth.

\section{LIN]IEY.-A SYNOPSIS OF THE BRITISH FLORA,}

Arranged according to the Natural Orders. By Professor John Lindley, Ph. D., F.R.S., ctic. New Edition, with numerous Additions and Improvements. 12mo. 10s. 6d. cloth.

\section{LINDLEY. - THE THEORY OF HORTICULTURE ;}

Or, an Attempt to Explain the Principal Operatious of Gardening upon Fhysiological Principles. By John Lindley, Ph.D. F.R.S. Svo. with Illustrations on IVood, 12s. cloth.

\section{LINDLEY.-GUIDE TO THE ORCHARD AND KITCHEN GARDEN;}

Or, an dccount of the most valuable Fruits and Vegetables cultivated in Great Britain: with Kalendars of the WVork required in the Orchard and Kitchen Garden during every Month in the Year. By George Lindley, C.M.H.S. Edited by Professor Liudley. Svo.16s. boards.

\section{LINWOOD (W.)-ANTHOLOCIA OXONIENSIS ;}

Sive, Florilegium e lusibus poeticis diversorum Oxoniensium Græcis et Latinis decerptam. Curante Gulielmo Linwood, M.A. Edis Christi Alummo. 8vo. 14s". cloth.

\section{LOUDON (MRS.) - THE AMATEUR GARDENER'S CALENDAR:}

Being a Monthly Guide, as to what should be avoided as well as what should be done in a Garden in each Month: with plain Rules how to do what is requisite ; Directions for laving out and plantilig Kitchen and Flower Gardens, Pleasure Grounds, and Shrubberies: and short account, in cach Month, of the Quadrupeds, Birds, and Insects, then most injurious to Gardens. By Mrs. Loudon, 16mo. with numerous Wood Engravings, 7s. 6d. cloth.

\section{LOUDON (MIRS.) - THE LADY'S COUNTRY COMPANION}

Or, How to Enjoy a Country Life Rationally. By Mrs. Joudon, author of "Gardening for Ladies," etc. New Edition. Foolscap 8vo., with Plate and Woodcuts, 7s. $6 d$. cloth.

\section{LOUDON (J.C.)-SELF.INSTRUCTION FOR YOUNG GARDENERS,}

Foresters, Bailiffs, Land Stewards, and Farmers; in Arithmetic, Book-keeping, Geometry, Mensuration, Practical Trigonometry, Mechanics, Land-Surveying, Levelliny, Planning and Mapping, Architectural Drawing, and lsometrical Projection and Perspective; with Examples showing their applications to Horticultural and Agricultural Purposes. By the late J. C. Londun, li.L.S. H.S. ete. With a Portrait of Mr. Luudon, and a Micmoir by Mrs. Loudon. 8vo, with Wood Engravings, 7s.6a. cloth. 


\section{LOUDON.-AN ENCYCLOPAEDIA OF TREES AND SHRUBS ;}

Being the "Arboretum et Fruticetum Britannicum" abridged : containing the Hardy Trees and Shrubs of Great Britain, Native and Fureign, scientifically and popularly described: with their Propagation, Culture, and Uses in the Arts. By J. C. Loudon, F.L.S. etc. 8vo. witl upwards of 2,000 Engraving's on lWood, $2 l$. I6/s. clott.

A New Edition of the Original Work, in 8 vols. Svo. with above 400 octavo Plates of 'Trces, and upward s of :-,ov Woodcuts, rol. cloth.

\section{LOUDON.-AN ENCYCLOP EDIA OF GARDENING;}

Presenting in one systematic view, the History and Present State of Grardening in all Coun tries, and its Theory and Practice in Great Britain: with the Managentent of the Kitchen Garlen, the Flower Garden, Laying-out Grounds, etc. By J. C. Loudon, F.L.S. etc. A new Elition. Svo. with nearly 1,000 Fingravings on Wood, 2l. jus. cloth.

\section{LOUDON.-AN ENCYCLOPAEDIA OF AGRICULTURE;}

Comprising the Theory and Practice of the Valuation, Transfer, Laying-out, Improvement, and Manayement of Landed Property, and of the cultivation and economy of the Animal and Vegetable Productions of Agriculture, including all the latest improvements. Fy J. C. Loudon, F.L.G.Z. and H.S. etc. Fifth Fdition. 8vo. with upwards of I, I00 Engravings on Wood, by Branston, $2 l .10 \mathrm{~s}$. cloth.-The Supplement, separately, $5 \mathrm{~s}$. sewed.

\section{LOUDON.-AN ENCYCLOP FEDIA OF PLANTS:}

Including all the Plants which are now found in, or bave been introduced in to, Great Britain ; giving their Natural History, accompanied by such Descriptions, Engraved Fioures, and Elementary Details, as may enable a beginner, who is a mere English reakter, to discover the name of every Plant which he may find in flower, and acquire all the information respecting it which is useful and interesting. By J. C. Loud on, I.L S., etc. The Specific Characters by an Eminent Botanist; the Drawings by J.D.C. Sowerby, F.L.S. A new Edition, with a new Supplement and a new Index. 8ro, with 11 early 10,000 Wood Engravings, 73s. 6d. cloth.

\section{LOUDON.-AN ENCYCLOPAEDIA OF COTTAGE, FARM, AND VILLA} AlRCHITFCTURE and FURNITURE. Containing Designs for Cottages, Villas, liarm Houses, Farmeries, Country Inns, Public Houses, Parochial schools, ete.; with the requisitc Fittinus-up, Fixtures, and Furniture, and appropriate Offices, Gardens, and Garden Scenery: each Nesign accompanied by Analvtical and Critical Remirks. By J. C. Loudon, F.L.S. etc. New Edition, Edited by Mrs. Loudon. Svo. with more than 2,000 Engravings on Wood, 63s. cloth.-The Supplement, sepurately, 8vo.7s. $6 d$. scwed.

\section{LOUDON.-HORTUS BRITANNICUS:}

A Catalogue of all the Plants indigcnous to or introduced into Britain. New F.dition, with a Supplement, prepared, linder the direction of J. C. Loudon, by W. H. Baxter, and revised by George 1) on, F.L.S. 8vo. 3Is.6d. cloth.

\section{LOUDON. - THE SUBURBAN GARDENER AND VILLA COMPANION:}

Comprising the Choice of a Villa or Suburban Residence, or of a Situation on which to form one; the Arrangement and Furnishing of the House; and the Laying-out, Planting, and general Management of the Gurden and Ground ; the whole adapted for Grounts from one perch to fifty iceres and upwards in extent; intended for the instruction of those who lnow little of Gardening or Rural Affairs, and morc particularly for the usc of Ladics. By J.C. Loudon, F..L.S., ete. 8vo. with above 300 Woud Engravings, 20s. cloth.

\section{LOUDON.-HORTUS LIGNOSUS LONDINENSIS}

Or, a Catalogue of all the Ligneous Plants cultivated in the ncighbourhood of London. To which are added their usual Prices in Nurseries. By J.C.Loudon, F.L.S. etc. 8vo.78.6d.

\section{LOW.-ON LANDED PROPERTY, AND THE ECONOMY OF ESTATES:}

Comprehendine the Relations between Landlorl and Tenant, and the Principles and Forms of Leascs; of Farm Buildings, Enclosures, Drains, Embankments, Roads, and other Rural Works, Minerals, and Woods. By bavid Low, Esq.F.R.S.E. etc., author of "Elements of Practical Agriculture," etc. 8vo. with numerous Wood Engravings, 21s. clotls.

LOW.-AN INQUIRY INTO THE NATURE OF THE SIMPLE BODIES OF CHEMISTRY. By D. Low, F.R.S.E. P'rofessor of Agriculture in the University of Edinburgh; author uf "Elements of Practical Agriculture," "A Treatise on Landed ['roperty and the Jcoucmy of kistrtes," "A Treatisc on the Breeds of the British Domesticated Animits," "The Breeds of the Domesticated Arimals of Great Britain Illustrated and Described." 2d Edition, enlarged and improved. Svo. $9 s$. cloth.

LOW.--ON THE DOMESTICATED ANIMALS OF GREAT BRITAIN,

Comprehending the Natural and Economical History of the Species and Breeds; Illustrations of the Properties of Exterual Form; ind Observations on the Principles and Practicc of Breding. By bavid Low, Esq., li.R.S.E., Professor of Agriculture in the University of Ecinburgh, ctc.; author of "Elements of Practical Agriculture," etc. 8vo. with Engravings on Wood, iss. cloth. 
LOW.-THE BREEDS OF THE DOMESTICATED ANIMALS OF CREAT

BRITAIN lescribed. By David Low, F.sq. F.R.S.E., Professor of Agriculture in the University of Edinburgh, etc. The Plates from drawings by W. Nicliolson, R.S.A., redured from a Series of Oil Paintinys, exccuted for the Agricultural Muscum of the University of Edinburyh, by W. Shiels, R.S.A. 2 vols atlas quarto, with 56 Plates of Animals, beautifully coloured after Nuture, $16 l .16 \mathrm{~s}$. half-bound in morocco.

Orill four separate portions, as follow:-

The OX. 1 Vol. With 22 Plates, price $6 l$. 16s. $6 d$. half-bound morocen.

The SHEFP. 1 Vol. With 21 Plates, price

$67.16 s .6 d$. half-bound morocco.
The HORSE. 1 Vol. With 8 Plates, price 3l. hrlf-bound morocco.

The HOG. ] Vol. With 5 Plates, price 2l.2s. half bound morocco.

\section{LOW.-ELEMENTS OF PRACTICAL ACRICULTURE;}

Comprehending the Cultivation of Plants, the Husbandry of the Domestic Animals, and the Economy of the Farm. By David Low, Esq.F.R.S.E., Professor of Agriculture in the University of Edinburgh. New Edition. 8vo. with an entirely new set of above 200 Woodcuts, :2ls. cloth.

MACAULAY.-CRITICAL AND HISTORICAL ESSAYS CONTRIBUTED TO THE F.DINBURGH REVIFW. By the Right Hon. Thomas Babington Macaulay, M.P. New Euition. 3vols.8vo.36s.clotli.

\section{MICAULAY.-THE HISTORY OF ENGLAND.}

From the Accession of James II. By Thomas Babington Macaulay. Vols. I. and II. 8vo. [In the press.

\section{MAC IULAY.-LAYS OF ANCIENT ROME.}

With "Ivry" and "The Armada." By the Right Honorable Thomas Babington Macaulay, M.P. New Edition. 16mo.4s.6d.clotli; moroceo, 10s. 6d. (by Hayday).

\section{MACAULAY - MR. MACAULAY'S LAYS OF ANCIENT ROME.}

A Ner Edition. With numcrous Illustrations, Original and from the Antique, drawn on Wood by George Scharf. jull.; and engraved by Samuel Williams. Fep. 4to. 2ls. boards; moroceo, 42s. (bound by Hayday).

MACKAY (CHARLES).-THE SCENERY AND POETRY OF THE ENGLISH LAKES: a Summer Ramble. By Charles Mackay, Esq. LL.D. author of "Legends of the Isles," "The Salamandrine," "The Thames and its Tributaries," etc. Svo. with beautiful Wood Engravings from Original Sketches, 14s. cloth.

\section{MACKINTOSH (SIR JAMES).-THE LIFE OF SIR THOMAS .MORE.} By the Right Hon. Sir James Mackintosh. Reprinted from the Cabinet Cyclopxdia. Foolscap 8vo. with Portrait, 5s, cloth; or bound in vellum, $8 s$.

\section{MACKINTOSI'S (SIR JAMES) MISCELLANEOUS WORKS;}

Including his Contributions to The FDINBURGH REVIEW. Edited by Robert James Mackintoslı, Esq. 3 vols. $8 v o .42 s$. clotlı.

M'CULLOCH.-A DICTIONARY, GEOGRAPHICAL, STATISTICAL, AND HISTORICAL, of the various Countries, Places, and Principal Natural Objects in the World. By J.R. M'Culloch, Fsq. A new Edition. 2vols. Svo. with Six large Maps, 4l. cloth.

* * The new Articles are printed separately as a Supplement to the former Edition. They comprise a full account of the present state of the United Kingdom, the Oregon Territory, etc. $8 v 0.58$. sewed.

M'CULLOCH.-A DICTIONARY, PRACTICAL, THEORETICAL. AND HISTORICAL, OF COMMERCE, AND COMMERCIAL NAVIGATION. BY J. R. M 'Culloch, Esq. A New Edition, corrected, cularged, and improved. 8vo. with Maps and Plats, 50s. cloth; or 55s. strongly lialf-bound in russia.

A SUPPLEMENT to the Editions published in 1844 and 1846 may be had separately, price 4s.6d, sewed.

\section{M'CULLOCH.-A TREATISE ON THE SUCCESSION TO PROPERTY} VACANT BY J)EATH : including lnquiries into the Influence of Primogeniture, Entails, the Law of Compulsury Partition, Foundations, etc. over the Public Iuterests. By J. R. M'Culloch, Esq. 8vo.6s.6d. cloth.

I'CULIOCH (J. R.)-AN ACCOUNT, DESCRIPTIVE, AND STATISTICAL, of the BRITISH EMPIRE; cxhibiting its Extent, Physical Capacities, Population, Industry, and Civil and licligious listitutions. By J. R. Mc Culloch, Esq. 3d Erlition, corrected, enlarged, and greatly improved. 2 thick vols. 8 vo. $42 s$. cloth. 


\section{M'CULLOCH. -THE LITERATURE OF POLITICAL ECONOMIY;}

Being a Classified Catalogue of the principal Works in the different departments of Political Economy, interspersed with Historical, Critical, and Biograplical Notices. By J.K. M'Culloch, Esq. 3vo. 14s. cloth.

I'CULLOCH, - A TREATISE ON THE PRINCIPLES AND PRACTICAL INFLUENCE OF TAXATION AND THE FUNDING SYSTEM. BYJ.R. M'Culloch, Esq. 8vo. 10s, cloth.

\section{MADAME DE MALGUET:}

A Tralc of 1820. 3 vols. post 8 vo. 31 s. 6 d. boards .

"One of the most fascinating productions of the present day. The story is well told; "nd the incidents are all wrouped together with the slivil of a painter and the hand of a master. Fen wourks of fiction have appeared at anl time, and fewer still in more recent days, which will bear any comparison with this, in all the essential attributes of a good novel."

\section{Observer.}

\section{MAITLAND (DR. CHARLES).-THE CHURCH IN THE CATACOMBS:}

A Jescription of the Primitive Church of Rome, illustrated by its Sepulchral Rcmains. By Charles Maitland, M.D. New Edition, revised, 8vo. with numerons Lingravings on Wood. 1 s. cloth.

\section{MARCET.-CONVERSATIONS ON CHEMISTRY:}

In which the Elements of that Science are familiarly Explained and Illustrated by Experiments. By Mrs. Marcet. New Edition, corrected, 2 vols. foolscap 8vo. 14s. cloth.

\section{MIARCE'T.-CONVERSATIONS ON NATURAL PHILOSOPHY ;}

In which the Flements of that Science are familiarly explained, and adapted to the comprehension of Young Persons. By Mrs. Marcet. New Ldition, enlarged and corrccted. Fcap. 8vo. with 23 Plates, 10s.6d. cloth.

\section{MARCET.-CONVERSATIONS ON POLITICAL ECONOMY:}

In which the Elements of that Seience arc familiarly cxplained. By Mrs. Marcet. Ncw Edition, revised aud enlarged. Foolscap 8vo.7s.6d. cloth.

\section{MARCET.-CONVERSATIONS ON VEGETABLE PHYSIOLOGY;}

Comprehending the Blements of Botany, with their application to Agriculture. By Mrs. Marcet. New Edition. Foolscap Svo. with Four Plates, 9s, cloth.

\section{MARCET.CCONVERSATIONS ON LAND AND WATER.}

By Mrs. Marcet. New Fidion revised and corrected. Foolscup 8vo. with coloured Map sliewing the comparative Altitude of Mountains, $5 s .6 d$. cloth.

MARGARET PERCIVAL.

Ly the Author of "Amy Herbert." Edited by the Rcv. W. Sewell, B.D., Fellow and Tutor of Exeter College, Oxford. New Edition. 2 vols. foolscap 8vo. 12s. cloth.

\section{MARRYAT.-BORNEO AND THE EAST INDIAN ARCHIPELAGO.}

By Francis S. Marryat, late Midshipman of H.M.S. Samarang, Surveying Vessel, With many Drawings of Costume and Scenery, from Original Sketches made on the spot by Mr. Marryat. Imperial 8vo. with numerous Lithographic Plates and Wood Engravings, 31s.6d. cloth.

MARRYAT (CAPT.)-MASTERMIAN READY;

Or, the Wreck of the Pacific. Writtcn for Young People. By Captain Marryat, C.B. author of "Peter Simple," etc. 3 yols. fcap. 8vo , with 1 umerous Engravings on Wood, 22s.6d. cloth.

MARRYAT.-THE PRIVATEER'S MAN ONE HUNDRED YEARS ACO. By Captain F. Marryat, C.B. author of "Peter Simple," "Masterman Ready," etc. 2 vols. fcap. 8v0. 128, cloth.

\section{MIARRYAT. -THE MISSION :}

Or, Scenes in Africa. Written for Young People. By Captain Marryat. C.B., autlor of "Peter Simple," "Masterman Ready," etc. 2 vols. feap.8vo. 12s. clotl.

\section{MARRYAT.-THE SETTLERS IN CANADA.} Written for Young People. By Captain Marryat, C.B. author of "Peter Simple," "Masterman Ready," etc. New Edition. Fcap. 8vo. witl two Illustrations, 7s. 6d, clotl..

MATTEUCCI.- LECTURES ON THE PHYSICAL PHCNOMENA OF IIVING PBEINGS. By Signor Carlo Maticucci, Professor of the University of Piwa Translated under the supcrintendence of J. Pcreira, M.D. F.R.S. Vice.President of the Royal Medical and Chirurgical Society. 12mo.9s. cloth. 


\section{MAUNDER.-THE TREASURY OF KNOWLEDCE,}

And IIBRARY of RElFRFACE: a popular Compendium of Universal Knowledge. By Samuel Mannder. New Edition, revised throughout and enlarged. Foolscap 8vo.10s. eloth ; bound in roan, $12 s$.

* * The principal contents of the present new and thormghly revised editim of "The Trensury of Knowledge," are-" new und enlarged Euglish Licticnary, with a Grammar, Verbal Distinctions, and Exercises; " new Universul Guzpteer; " conpendious Clussicul Dictionary; an Analysis of History and Chronology; a Dictionnry of Law Terms; a new Synopsis of the British Peerage; and various useful tabular Addenda.

\section{MAUNDER.-THE SCIENTIFIC AND LITERARY TREASURY:}

A New and Popular Fncyclopredia of Scienee and the Belles Lettres; includingall Branehes of Scienee, and every Subject connected with Literature and Art. The whole written in a familiar style, adapted to the comprehension of all persons desirous of acquiring information on the subjeets comprised in the work, and also adapted for a Manual of eonvenient Reference to the more instructed. By Samuel Maunder. New Edition. Fcap.8vo.10s. clotli; bound in roan, $12 s$.

\section{MAUNDER.-THE BIOGRAPHICAL TREASURY:}

Consisting of Memoirs, Sketches, and brief Notices of above 12,000 Eminent Persous of all Ages and Nations, from the Farliest Period of Histnry; forming a new and comp!ete Dic. tionary of Universal Biograph 7 . By Samuel Mannder. New Edition, revised throughout; with a copious Supplement. Foolscap Svo. 10s. cloth; bound in roan, 128.

\section{MAUNDER.-THE TREASURY OF HISTORY;}

Comprising a General Tntroductory Outline of Universal History, Ancient and Modern, and a Series of separate Histories of crery principal Nation that exisis; developing their Rise, Frogress, and Present Condition, the Moral and Social Character of their respective Inhabitants, their Religion, Manners, and Customs, etc.etc. Bysamuel Maunder. Niew Edit. Feap. 8ro. 10s. eloth; bound in roan, 123.

\section{MAUNDER.-THE TREASURY OF NATURAL HISTORY;}

Or, a Popular Dictionary of Animated Nature: in which Zooloyical Characeristics that distingnish the different Classes, Genera, and Species are combinte with a variety of interesting Information illustrative of the Habits, Instincts, and General fieonomy of the Aninal Kingdom. 'To which are added, a Syllabus of Practical Taxidermy, and a Glossarial Appendix. Fimbellished with Nine Hundred Engravings on Wood, from J rawings made expressly for this Work. 3y Samuel Maunder. Fcp. 8vo. with 900 Wondeuts, 10s, cloth; bound in roan, $12 s$.

\section{MEMOIRS OF THE CEOLOCICAL SURVEY OF GREAT BRITAIN,}

Ind of the Musem of Economie Geology in London. Published by order of the Iords Commissioners of Her Majesty's Treasury. Vol. I. Royal Svo. with Woodcuts and 9 Plates, (seven eoloured), 21s. cloth; and Vol. II. in two thick Parts, with 63 Plates (thre coloured) and numerous Woodcuts, 42s. cloth, or, separately, 21s. each Part.

\section{MILES(W.)-THE HORSE'S FOOT,}

And How to Keep it Sound. By William Miles. Fsq. New Fdition, with an Appendix on Shoeing in Feneral, aud Hunters in Particular. Imperial 8vo. with Engravings, 9s. clotlı.. The Appendix separately, price $2 s .6 d$.

*** Four casts or models of Shops may be had, displaying the different hinds of shoping, price 3s. each; or 10s. 6r. the set. - No. 1. Shod for treneral purposes. - No. 2. Shod for Hunting.-No. 3. Shod with Leather. - No. 4. Foot prepared for Shoeing.

\section{MILNER (REV. J. AND I.) - THE HISTORY OF THE CHURCH OF} CHRIST. By the Rev. Joseph Milner, A.M. With Additions and Corrections by the late Rev. Isanc Milner, D.D.F.R.S. A New Edition, revised, with aditional Notes. by the Rev. Thomas Grantham, B.D., Chaplain to the Bishop of Kildare. 4 vols. 8vo. 52s. eloth.

\section{MIRACLES OF OUR SAVIOUR.}

With riel and appropriate Borders of Original Design, a series nf Illuminatcd Figures of the Apostles from the Old Masters, six Illuminated Miniatures, and other Fimbellishments. By the Illminator of the "Parables." Square fcap. Svo. in massive carved covers, $21 s$.; or bound in morocco, in the missal style, 30 s.

MITCHELL.-IOURNAL OF AN EXPEDITION INTO THE INTERIOR OF TROPICAI, AUSTRAIAA, in seareh of a Route from sydney to the Gulf of Carpentaria. By Jieut.-Colonel Sir T. L. Mitthell, Knt. D.C.L. Surveyor-General of New South Wrles, and late elective Member of the Legislative Conncil of that Colong. Svo. with Maps, Views, and Engravings of Objeets of Natural History, $2 \mathrm{l} s$, cloth. 
MOHAN LAL. - LIFE OF THE AMIR DOST MOHAMMED KHAN OF KABUL: with his Political Proceedings towards the English, Russian, aud Pcrsian Governments, including the Victory and Disasters of the British Army in Affuhunistall. By Molatn Lal, Fsq., Knight of the Persian Order of the Lion and Sun; lately attached to the Mission in Kabul. 2 vols. 8 vo. witl 11 merous Portraits, $30 \mathrm{~s}$. cloth.

\section{MIONTGOIIERY'S (JAMES) POETICAL WORKS.}

New and only complete Edition. With some additional Poems, and Autobiographical Prefaces. Collected and edited by Mr. Montgomery. 4 vols. foolscap 8vo. with Portrait, and seven other Plates, $20 s$. cloth; bound in morocco, $1 l .16 s$.

\section{MOORE'S POETICAL WORKS;}

Containing the Author's rccent Introduction and Notes. Complete in one volume, uniform with Lord Bpron's Poems. Medium 8vo. with Portrait and Vignette, 1l. 1s. cloth; or 42s. bound in moroceo, by Hayday.

* * Also, an Edition in 10 vols. foolscap 8vo. with Portrait, and 19 Plates, 2l.10s. cloth; moroce, $4 l .10 s$.

\section{MOORE'S LALLA ROOKH. AN ORIENTAL ROMANCE.}

New Edition. Medium 8vo.illustrated with 13 file Engravings,21s. cloth; morocco, 35s.; with India Proof Plates, 42s. cloth.

\section{MOORE'S LALLA ROOKH. AN ORIENTAL ROMANCE.}

New Edition. Foolscap 8vo. with 4 Plates, by IVestall, 10s. 6d. cloth; or 14s. bound in morocco.

\section{MOORE'S IRISH MELODIES.}

Illustrated by D. Maclise, R.A. Imp.8vo, with 161 Designs, engraved on Steel, $3 l .3 s$. boards; or 4l.14s.6d. bound in morrocco, by Hayday. Proof Impressions (only 200 copies printed, of which a few remain), $6 l .68$. boards.

** India Proofs before letters of the 161 Designs, on Quarter Colombier, in Portfolio conly 25 copies printed, of which a few remuin), 31l. $10 s$.

Indir Proofs before letters of the 51 large Designs, on Quarter Colombier, in Portfolio (ouly 25 copies printed, of which a few remain), 18l. 18 s.

\section{MIOORE'S IRISH MELODIES.}

New Edition. Fcap. Svo, with Vignette Title, 10s. cloth; bound in morocco, 13s.6d.

\section{MOORE.-THE POWER OF THE SOUL OVER THE BODY,}

Considered in relation to Health and Morals. By George Moore, M.D. Member of the Royal College of Physicians, London, etc. New Edition. Post 8vo.7s.6d. cloth.

\section{MIOORE.-THE USE OF THE BODY IN RELATION TO THE MIND.}

By George Moore, M.D. Member of the Royal College of Physicians, London, etc. New Edition. Post 8vo.9s. cloth.

\section{MOORE.-MAN AND HIS MOTIVES.}

By George Moore, M.D. Member of the Royal College of Physicians, Loudon, etc.; anthor of "The Power of the Soul over the Body," and "The Use of the Body in relation to the Mind." Pust 8vo. 8s. cloth.

\section{MORAL OF FLOWERS (THE).}

New Editio11. Royal 8vo. with 24 beautifully coloured Engravings, $1 l$. 10s. half-bound.

\section{MIOSELEY.-ILLUSTRATIONS OF PRACTICAL MECHANICS.}

By the Rev. H. Moseley, M.A., Professor of Natural Philosophy aud Astronomy in King's College, London; author of "The Mechanical Principles of Lingineering and Architecture." New Edition. Fcap.8vo. with Woodcuts, 8s. cloth.

\section{MOSELEY. - THE MECHANICAL PRINCIPLES OF ENGINEERING AND} ARCHITECTURF. By the Rev. H. Moseley, M.A.F.R.S., Professor of Natural Plilosophy and Astronomy in King's College, London; and anthor of "Illustritions of Practical Mechanics,"etc. 8vo, with Woodcuts and Diagrams, 1 .48. cloth.

\section{MOSIEIM'S ECCLESIASTICAL HISTORY,}

Ancient and Modern. Translated, with copious Notes, by James Murdock, D.D. New Hdition, revised, and continued, by the Rev.Henry Soames, M.A. 4 vols. 8vo. 48s. cloth. 


\section{MURRAY.-AN ENCYCLOPAEDIA OF GEOGRAPHY;}

comprising a complete Description of the Farth: exhibiting its Relation to the Heavenly Bodies, its Pliysical Structure, the Natural History of each Country, and the Industry, Commerce, Political 1nstitutions, and Civil and Social State of all Nations. By Hugh Murray, F.R.S.E. New Edition. 8vo. with 82 Maps, and upwards of 1,000 other Wood Engravings, $3 l$. cloth.

\section{NECKER DE SAUSSURE.-PROGRESSIVE EDUCATION;}

Or, Considerations on the Course of Life. Translated and Abridged from the French of Mudame Necker De Saussure, by Miss Holland. 3 vols. foolscap 8vo. 19s. 6d. cloth.

** Separately-vols. I. and 11. 12s.; vol. I11. 7s. 6d.

OWEN, - LECTURES ON THE COMPARATIVE ANATOMY AND PHYSIOLOGY OF THE INVERTEBRATE AN1MALS, delivered at the Royal College of Surgeons in 1843. By Richard Owen, F.R.S. Hunterian Professor to the College. From Notes taken by William White Cooper, M.R.C.S. and revised by Professor Owen. With Glossary and Index. 8vo. with nearly 140 Woodcuts, 14s. cloth.

\section{OWEN.LECTURES ON THE COMPARATIVE ANATOMY AND}

PHYSIOLOGY of the VERTEBRATF ANIMAIS, delivered at the Royal College of Surgeons in 1844 and 1846. By Richard Owen, F.R.s. Hunterian Professor to the College. I11 2 vols. Vol. I. 8vo. with numerous Woodcuts, 14s. clotls.

\section{PARABLES OF OUR LORD.}

Richly Illuminated with appropriate Borders, printed in Colours, and in Black and Gold; with a Design from one of the early German engravers. Square foolscap 8vo., uniform in size with the "Sermon on the Mount," $21 s .$, in a massive carved binding; morocco, $30 z .$, bound by Hayday.

\section{PARKES.-DOMESTIC DUTIES;}

Or, Instructions to Young Married Ladies on the Management of their Households and the Regulation of their Conduct in the various Relations and Duties of Married Life. By Mrs. W. Parkes. New Edition. Foolscap 8vo.9s, cloth.

\section{PARNELL.-A TREATISE ON ROADS,}

Wherein the Principles on which Roads should be made are explained andillustrated by the Plans, Specifications, and Cuntracts, made use of by Thomis Telford, Esq., on the Holvhead Road. By the Rt. IIon. Sir Henry Parnell, Bart. New Edition, enlarged. 8vo. with Nine Plates, 21s. cloth.

\section{PARROT.-THE ASCENT OF MOUNT ARARAT,}

By Dr. Friedrich Parrot, Professor of Natural Plilosophy in the University of Dorpat, Russian Imperial Councillor of State, etc. 'Transluted and Edited by IV. D. Cooley, Hsq. author of the "History of Maritime and Inland Discovery," etc. 8vo. with a Map by Arrowsmith, alld Wood cuts, 148 . cloth.

\section{PEREIRA.-A TREATISE ON FOOD AND DIET:}

With Observations on the Dietetical Regimen suited for Disordered States of the Diyestive Organs; and an Account of the Dietaries of some of the principal Metropolitan and other Establishments for Paupcrs, Lunatics, Criminals, Childrcu, the Sick, etc. By Jon. Pereira, M.D.F.1R.S., author of "Elements of Materia Medica." 8vo.16s. cloth.

\section{PERICLES :}

A Tale of Athens in the 83d Olympiad. By the Author of "A Brief Sketch of Greek Philosophy." 2 vols. post 8 vo. 18s. cloth.

\section{PESCHEL (C. F.)-ELEMENTS OF PHYSICS,}

By C.F. Peschel, Principal of the Royal Miritary Colłege, Dresden, etc.etc. Translated from the Germa1, witl Notes, by $\mathbb{E}$. West. 3 vols. fcap. Svo. with Woodeuts, $21 s$. cloth.

Separately $\left\{\begin{array}{l}\text { Part I. The Physics of Ponderable Bodies. Fiap. 8vo.7s.6d. cloth. } \\ \text { Part 11. Imponderable Bodies (Light, Heat, Magnetism, Electricity, }\end{array}\right.$ and Electro-Dynamics). 2 vols, fcap. Svo. 13s. 6 d. cloth.

PHILLIPS.-FIGURES \& DESCRIPTIONS OF THE PALAEOZOIC FOSSILS OF CORNIVALL, DEVON, and WEST SOMERSET; observed in the course of the Ordnance Geological Survey of that District. By John Phillips, K.R.S. F.G.S. ctc. Published by Order of the Lords Commissioners of H.M. Treasury. 8vo. with 60 Plates, conprising very numerous Figures, 98 . cloth. 


\section{PHILLIPS. - AN ELEMENTARY INTRODUCTION TO MINERALOGY;}

Comprising a Notice of the Cliaracter's, Properties, and Chemical Constitution of Minerals: with Accounts of the Places and Cireumstances in which they are found. By William Phillips, F.L.S. M.G.S.etc. A New Edition, eorreeted, enlarged, and improved, by W. H. Miller, M.A. F.R S. Professor of Mineralogy in the Unircrsity of Cambridge. 8vo. with numerous Wood Engravings. [In the press.

\section{PITMAN (THE REV. J. R.)-SERMONS}

On the principal Subjects comprised in the Book of Psalms, abridged from Eminent Divines of the Established Church. By the Rev.J. R. Pitman, A.M. Domestic Chaplain to Her Royal Highness the Duehess of Kent. 8vo. 14 s. cloth.

\section{PLUNKETT.-THE PAST AND FUTURE OF THE BRITISH NAVY.}

By Captain the Hon. F. Plunkett, R.N. 2d Edition, corrected and enlarged; with Notes, and New Information communicated by several Officers of Distinction. Post 8vo. 8s.6d. cloth.

\section{THE POCKET AND THE STUD;}

Or, How to procure and keep Horses, with some regard to obtaining the Animal required, and to keeping him ivithout emptying the Pocket. Being the result of many years' experience of "Harry Hieover." Foolscap 8vo. with a Portrait of "One of the Stud," from a sketch by "Harry Hieover."
[Nearly ready.

\section{POETS' PLEASAUNCE (THE);}

Or, Garden of all Sorts of Pleasant Flowers, which our Pleasant Poets have in Past Time (for Pastime) Planted. By Eden Warwick. Square crowil Svo. witl Twenty-nine Ornaniental Borders composed of Flowers and Insects, engraved on Wood, 30s. boards; or $45 s$. bound in morocco, by Hayday.

PORTLOCK. - REPORT ON THE GEOLOGY OF THE COUNTY OF LONDONDERRY, and of Parts of Tyrone and Fermanagh, examined and described under the Authority of the Master-General and Board of Ordnance. By J. E. Portlock, F.R.S.etc. 8 vo. with 48 Plates, $24 s$. cloth.

\section{PYCROFT.-A COURSE OF ENGLISH READING;}

Adapted to every'Taste and Capacity. With Anecdotes of Men of Genius. Bythe Rev. James Pyeroft, B.A., author of "Greek Grammar Practice," and "Latin Grammar Practice;" Editor of "Virgil, with Marginal References." Foolscap 8vo.6s. 6d. cloth.

RANKE (PROFESSOR).-RANKE'S HISTORY OF THE REFORMATION. Translated by Sarah Austin, translator of Ranke's "History of the Popes." Vols.I.and II. 8 vo. 30s.; Vol. III. 18s. cloth.

\section{READER (THOMAS).-TIME TABLES.}

On a New and Simplified Plan; to facilitate the Operation of Discounting Bills, and the Calculation of Interest on Banking and Current Aceounts, etc.: shewing, without calculation, the Number of Days from every Day in the Year to any other Day, for any Period not exceeding 365 Days. By Thomas Reader. Post 8vo. ]4s. cloth, or 17s. calf lettcred.

REID (DR.)-ILLUSTRATIONS OF THE THEORY AND PRACTICE OF VFNTILATION: with Remarks on Warming, Fxelusive Lighting, and the Communication of Sound. By D.B. Reid, M.D.F.R.S.E. ete. 8vo. with Engravings on Wood, 16s. cloth.

\section{RENAUD.-MATUTINA:}

Morming Readings, ehiefly Practieal, seleeted and original. Adapted to the use of the Younger Members of the Church of Engtand. By the Rev. George Renawd, M.A. late Fellow of C. C. C. Oxford. Fcap. 8vo. 5s, cloth.

REPTON.-THE LANDSCAPE GARDENING \& LANDSCAPE ARCHITECTURE of the late Humphrey Repton, Esq.; being his entire Works on these subjects. A New Fdition, with an Historical and scientifie Introduction, a systematic Analysis, a Biographical Notice, Notes, and a copious Alphabetical Index. By J. C. Loudon, F.L.S., etc. 8vo. with a Portrait and upwards of 250 Engravings, $30 \mathrm{~s}$. cloth; with coloured Plates, $3 l .68$. clotl.

\section{REST IN THE CHURCH.}

By the Author of "From Oxford to Rome: and, How it Fared with Some who lately made the Journey." New Edition. Fcap.8vo.6s.6d.cloth.

RICH.-AN ILLUSTRATED COMPANION TO THE LATIN DICTIONARY; Being a Dictionary of all the Words respecting Visible Objects eonnected with the Arts, Science, and Every-diny Life of the Aneients. Illustrated by about Two 'Thousand Eugravings on Wood, from the Antique. By Anthony Rich, jun. B.A. late of Caius College, Cumbridge; and one of the contributors to Dr. Smith's "Dictionary of Greek and Roman Antiquities." Post 8vo. with 2,000 Woodcuts, 18 s, eloth. 
RICHTER.-LEVANA; OR, THE DOCTRINE OF EDUCATION.

Translated from the German of Jean Paul Fr. Richter. Pust 8vo.10s. 6d. cloth.

RIDDLE.-A COMPLETE ENGLISH-LATIN AND LATIN-ENGLISH DICTlONARY, from the best sources, chietly Germall. By the Rev.J. E. Riddle, M.A. New Edition. 8vo.31s, 6d. woth.

* Separately-The Euglish-Latin Dictionary, 10s.6d.; the Latin-English Dietionary, $21 s$.

\section{RIDDLE.-A DIAMOND LATIN-ENGLISH DICTIONARY .}

A Guide to the Meaning, ?Qunlity, and right Accentuation of Latin Classical Irords. By the Rev.J.E. Riddle, M.A. New Edition. Royal $32 \mathrm{mo.} 4 s$. bound.

\section{RIDDLE.-LETTERS FROM AN ABSENT GODFATHER:}

Or, a Compendium of Religious Instruction for Young Persons. By the Rev.J. E. Riddle, M.A. Foolscap Svo.6s. cloth.

\section{RHDDLE.-ECCLESIASTICAL CHRONOLOCYY}

Or, Annals of the Christian Church, from its Foundation to the present Time. Containing 3 View of General Chureh History, and the Course of Secular Fvents; the Limits of the Church and its Relations to the State; Controversics; Sects and Partics; Rites, Institutions, and Diseipline; Ecclesiastical Writers, etc. By the Rev.J. E. Riddle, M.A. Svo. 15s. cloth.

RITCIIE (ROBERT.)-RAILWAYS: THEIR RISE AND PROGRESS, AND CONSTRUCTION, with Remarks on Railway Accidents, and Proposals for their Prevention. By Robert Ritchie, Esq., F.R.S., S. A., Civil Fingineer, Associate of the Institution ot Civil Engineers, etc. Fcap. 8vo. with Woodcuts and Diagrams, 9s. cloth.

\section{RIVERS.-THE ROSE AMATEUR'S GUIDE :}

Containing ample Descriptions of all the fine leading varieties of Roses, regularly classed in their respective Families; their History and Mode of Culture. By T. Rivers, Jull. Fourth Edition, corrected and improved. Foolseap 8vo.6s, cloth.

ROBINSON. -THE WHOLE ART OF MAKING BRITISH WINES, CORDIALS, AND LIQUEURS, IN THE GREATEST PERFECTION ; AS ALSO STRONG AN1 CORDIAL WATERS. To which is added, a Collection of Valuable Recipes for Brewing Fine and Strong Ales, and Miscellaneous Articles conneeted with the Practice. By James Robinson. Ficap. 8vo.6s. cloth.

ROBINSON (JAMES).-THE WHOLE ART OF CURING, PICKLING, and SMOKING MEAT and FISH, both in the British and Foreign Modes. With many useful Miseellaneons Recipes, and full Directions for the Construction of an Econonical Drying Chimney and Apparatus, on an entirely new Plan. By James Robinson, Eighteen Years a Practical Curer. Fcap. 8vo. 4s.6d. cloth.

\section{ROGERS. - THE VEGETABLE CULTIVATOR:}

Containing a plain and accurate Description of all the different Species of Culinary Vegetables, with the most approved Method of Cultivating them by Natural and Artificial Means, and the best Modes of Cooking them. By John Rogers, author of "The Fruit Cultivator." New Edition. Foolscap 8vo.7s. cloth.

ROGET.-THE ECONOMIC CHESS-BOARD:

Being a Chess-Board, provided with a eomplete set of Chess-Men, for playing Games in carriages, or out of doors, and for folding up, and carrving in the pocket, without dis. turbing the Game. Invented by P. M. Ruget, M.D. and registered according to Act of Parliament. New Edition. In a neat fcap. 8vo, case, price $2 s .6 d$.

\section{ROWTON. - THE FEMALE POETS OF GREAT BRITAIN,}

Chronologically arranged: with copious selections, and Critieal Remarks. By Frederic kow toll, author of "The Debater," etc. Square crown 8vo. 14s. cloth.

\section{ROWTON (F.) - THE DEBATER;}

Beiny a Series of eomplete Debates, Outlines of Delates, and Questions for Discussion. With ample references to the best sources of information upon each particular topic. By Frederic Rowton, Lecturer on General Literature. Foolscap \&vo. 6s. cloth.

\section{SANDBY.-MESMERISM AND ITS OPPONENTS.}

By George Sandby, M.A. Vicar of Flixton, Suffolk. Second Edition, considerably enlarged with an introductory Chapter on the Hostility of Scientific and Medical Men to Mesmerism. 16 no. 5s. cloth; or in two Parts, $2 s$. each, sewed.

SANDFORD (REV. JOHN).-PAROCHIALIA, or Church, School, and Parish. By the Rev. John Sandford, B.D. Viear of Dunehurch, Chaplain to the lord lishop of Worcester, Hon. Canon of Worcester, and Rural Dean. 8vo. with numerous Wodeuts, 16s. eloth. 
SANDFORD. - WOMAN IN HER SOCIAL AND DOMESTIC CHARACTER. By Mrs. John Sandford. 6th Edjition. Foolscap 8vo.6s. cloth.

\section{SANDFURD.-FEMALE IMPROVEMENT.}

By Mrs. John Sandford. New Eùition. Foolscap Svo.7s. cloth.

\section{SCHOMBURGK.-THE HIISTORY OF BARBADOS:}

Cumprising a Geographical and Statistieal Description of the Island; a Sketch of the Historical Hvents since the Settlement; and an Account of its Geoloyy and Natural Productions. By Sir Robert H. Selomburgk, Ph.D.K.R.E. etc. Royal svo. witl Chart, Views, and Engraviugs, $31 s .6 d$. cloth.

SCHOMBURGK.-A TOPCGRAPHICAL MAP OF THE ISLAND OF BARBADOS, based upon Mlayo's (Original survey in 1721, and eorrected to the year 1846. By Sir Rnbert H. Schomburgk, Ph.D. K.R.E. Engraved by Arrowsmith, on 2 large sheets, 21s. coloured.

\section{SCHOPENHAUER - YOUTHFUL LIFE AND PICTURES OF TRAVEL:}

Being the Autobiography of Madame Schopenhauer. Translated from the German. 2 vols. foolscap 8 vo. $12 \mathrm{~s}$. boards.

\section{SEAWARD.-SIR EDWARD SEAWARD'S NARRATIVE OF HIS SHIPWRECK,} and eonsequent Discovery of certain Islands in the Caribbean Sea: with a Detail of many extraorlinary and highly interesting fivents in his Life, from 1733 to 1749 , as written in his own Diary. Elited by liss Jane Porter. New Edition. 2 vols. post 8vo.21s. cloth.

\section{SELECT WORKS OF THE BRITISH POETS :}

lrom Chaucer to Withers. With Biographical Sketches, by R. Southey, LL.D. Medium 8vo. 30s. cloth; or, with gilt edges, 31 s. $6 d$.

\section{SELECT WORKS OF THE BRITISH POETS:}

From Ben .Jonson to Coleridge. With Biographical and Critical Prefaces by Dr. Aikill. A New Edition, with additional Seleetions, from more reeent Poets, by Luey Aikin. Medium 8 vo. 18s. cloth.

* * The peculiar feature of these two worksis, that the Poems included are printed entire without inutilation or abridgment.

\section{THE SERMON ON THE MOUNT.}

Intencled as is Birthday-Present, or Gift-Book for all Seasons. Printed in Gold and Colours, in the Missal Stgle; with Ornamental Borders bo () well Jones, Architect, and an llluminated Frontispiece by W. Boxall, Esq. A vew edition. Foolscap 4 to. in a rich brocaded silk cover, $21 s . ;$ or bound in morocco, by Hayday, $25 s$.

\section{SHAKSPEARE, BY BOWDLER.}

THE FAMHLY SHAKSPEARE, in which nothing is added to the Original Text; but those WVords and Fxpressions are omitted which eamnot with propriety be read aloud. By T. Bowdler, Esq. F.IR.S. New Edition. 8vo, with 36 Illustrations after Smirke, etc., 21s. eloth; or, without Illustrations, 8 vols. 8 vo. $4 l .14 s, 6 d$. boards.

\section{SHORT WHIST :}

Its Rise, Progress, and Laws; with the reeent Deeisions of the Clubs, and Oloservations to make any one a Whist Player. Containing also the Laws of Piquet, Cassino, Ecarte, Cribbage, Bachgammon. By Major $\mathrm{A} *{ }^{*} * *^{*}$ New Edition. Towhich are added, Precepts for Tyros. By Mrs. B ***** Fonlscap 8 vo.3s. clnth, gilt edges.

\section{THE GOOD SHUNAMIMITE.}

From the Scriptures-2 Kings, chap. IV. 8 to 37. With Six Original Designs by A. Klein, and an Ornamental Border to each page, in the Missal stylc, by L. Gruner. Printed in Colours and Gold. Square feap. Svo. uniform in size with "Mliracles of our Lord," 2ls. in massive carved covers; or 308 . bound in morocu, in the Missal style.

\section{SINCLAIR.-THE BUSINESS OF LIFE.}

By Catherine Sinclair, author of "The Journey of Life," "Jane Bouverie," "Modern Accomplishments," "Moder" Srciety," etc. 2 vols. fcap. 8 ro. $10 \mathrm{~s}$. cloth.

"The book, withont being of a directly devotional charucter, or belonging to the class of light reading, combines several of the best qualities of both, and nakes general literature and entertainino anecdote serve as handmaids to religions iustruction. We have seen many pumpons treatigss containing not half the tulent or a tithe of the hnowledge compressed into these unpretending lettle volumes."-Britallia. 
SINCLAIR.-THE JOURNEY OF LIFE.

By Catherine Sinclair, author of "The Business of Life," "Modern Society," "Jane Bonverie," etc. New Edition, corrected and enlarged. Fcap. 8vo.5s. cloth.

SINNETT.-BY-WAYS OF HISTORY, FROM THE TWELFTH TO THE SIXTEENTH CENTURY. By Mrs. Percy Simnett. 2 vols. post 8vo. 18s. cloth.

\section{THE SKETCHES ;}

Three Tales. Br the Authors of "Any Herbert," "The King's Messengers," and "Hawkstone." New Edition. Feap. 8vo. with six Plates, 8s. cloth.

\section{SMITH.-SACRED ANNALS :}

Or, Researches into the History and Religion of Mankind, from the Creation of the World to the Death of Isaac: derluced from the Writings of Moses and other Inspired Authors, eopiously illustrated and confirmed by the ancient Records, Traditions, and Mythology of the Heathen World. By Georgc Smith, F.S.A.etc. author of "The Religion of Ancient Britain," etc. Crown Svo. 10s. cloth.

SMITH (GEORGE).-THE RELIGION OF ANCIENT BRITAIN HISTORICALLY CONSIDERED: Or, a Succinct Account of the several Religious Systcms which have obtained in this Island from the Farliest Times to the Norman Conquest: including an Investigation in to the Early Progress of Error in the Christian Chureh, the Introduction of the Gospel into Britain, and the State of Religion in England till Popery had gained the A scendancy. By George Smith, F.A.S. New Edition. 8vo.7s.6d.cloth.

\section{SMITH (GEORGE).-PERILOUS TIMES:}

Or, the Agressions of Anti-Christian Error on Scriptural Christianity: considered in reference to the Dangers and Duties of Protestants. By George Smith, F.A.S. Member of the Royal Asiatic Society, and of the Royal Society of Literature. Foolseap 8vo. 6s. cloth.

\section{SMITH (JAMES).-THE VOYAGE AND SHIPWRECK OF SAINT PAUL:}

with Dissertations on the Sources of the Writings of St. Luke, and the Ships and Navigation of the Antients. By James Smith. Esq. of Jordarihill, F.R.S.etc. Svo. with illustrative Views, Charts, and Woodcuts, 14s. clotl.

\section{SIITH.-AN INTRODUCTION TO THE STUDY OF BOTANY.}

By SirJ. F. Smith, late President of the Linnan Society, 7th Edition, corrected; in which the object of Smith's "Grammar of Botany" is combined with that of the "Introduction." By Sir William Jackson Hooker, K.H. LL.D. etc. Svo. with 36 Steel Plates, 16s. cloth; with coloured Plates, 2l.12s.6d. cloth.

SMITH.-COMPENDIUIM OF THE ENGLISH FLORA.

By Sir J.E. Smith. New Edition, with Additions and Corrections. By Sir W.J.Hooker. 12 mo.7s. 6 . cloth.

THE SAME IN LATIN. New Edition. 12mo.7s.6d.

SMITII.-THE ENGLISH FLORA.

By Sir James Fdward Smith, M.D. F.R.S., late President of the Linnaan Society, ctc. 6 vols. 8 vo. $3 l .12 s$. boards.

SMITH (SYDNEY). - SERMONS PREACHED AT ST. PÁUL'S CATHEDRAL, the Foundling Hospital, and several Churches in London; together with others addressed to a Country Congregation. By the late Rev. Sydncy Smith, Canon Residentiary of St. Paul's Cathedral. 8vo.12s, cloth,

SMITH.-THE WORKS OF THE REV. SYDNEY SMITH. New Edition, with Additions. 3 vols.8vo. with Portrait, 36s. cloth.

SOAMES.-THE LATIN CHURCH DURING ANGLO-SAXON TIMES. By the Rev. Henry Soames, M.A., Editor of "Mosheim's Institutes of Ecclesiastical History." 8vo. 14s. clotll.

SOME PASSAGES FROM MODERN HISTORY.

By the Author of "Letters to My Unknown liriends," and "Twelve Years Ago." Foolscap Svo.6s. 6d. clotll.

SOPHOCLES, BY LINWOOD.

SOPHOCLIS TRAGCDIAi SUPERSTITES. Recensuit, ct brevi adnotatione instruxit Gulichnus Linwood, A.M. Adis Christi apud Oxonienses Alumnus. Svo.16s. cloth. 
SOUTHEY (ROBERT). - THE LATE MR. SOUTHEY'S COMMONPLACE BOOK; comprising his Readings and Collections in History, Biography, Manners and Literature, Voyages and Travels, etc.e ete.

SOUTHEY (RCBERT).-THE DOCTOR, ETC.

By the late Robert Southey. A New Edition, eomplete in One Volume. Edited by the Author's Son-in-Law, the Rev. John Wood WVarter. Square crown 8vo., with Portrait, Vignette Title-page, and Bust of the Author, $2 \mathrm{t} s$. cloth.

SOUTHEY.-THE LIFE OF WESLEY, And Rise and Progress of Methodism. By Robert Sonthey, Esq. LL.D. New Edition, with Notes by the late Samuel Taylor Coleridge, Esq., and Remarks on the Life and Ch:tracter of John Wesley, by the late Alexander Knox, Esq. Fdited by the Rev. Charles Cuthbert Southey, A.M. Curate of Cockerinouth. 2 vols. 8 vo. with two Portraits, 11 . $8 s$. cloth.

\section{SOUTHEY'S (ROBERT) COMPLETE POETICAL WORKS :}

Containing all the Author's last Introductions and Notes. Complete in One Volame, $24 s .6 d$. with Portrait and Vignette, uniform with Byron's and Moore's Poetical Works. Medium 8vo. $21 s$. cloth; or $42 s$. bound in morocco, by Hayday.

Also, an Edition in 10 vols. foolscap 8vo. with Portrait and 19 Plates, 2l. 10s.; morocco, $4 l .108$.

\section{SPIRIT OF THE WOODS (THE).}

By the Author of "The Moral of Flowers." New Edition. Royal 8vo. with 23 beautifully coloured Engravings of the Forest Trees of Great Britain, 1l.11s. $6 d$. cloth.

STABLE TALK AND TABLE TALK; OR, SPECTACLES FOR YOUNC SPORTSILEN. By Harry Hieover. 2 vols. 8vo. with Portrait, 24s. cloth.

\section{STEEL'S SHIPMASTER'S ASSISTANT.}

Compiled for the use of Merchants, Owners and Masters of Ships, Officers of Customs, and all Persons conneeted with Shipping or Commerce ; containin the Law and Local Regula tions affecting the Owmership, Charge, and Management of ships and their Cargoes ; together with Notices of other Matters, and all neeessary Information for Mariners. New Edition, rewritten throughout. Edited by Graham Willmore, Esq. M.A. Barrister-at-Law George Clements, of the Customs, London, and William Tate, author of "The Modern Cambist." 8ro.28s. cloth; or 298 . bound.

STEPHEN.-THE HISTORY OF THE CHURCH OF SCOTLAND,

From the Reformation to the Present Time. By Thomas Stephen, author of "The Book of the Constitution," "Spirit of the Church of Rome," etc. 4 vols. 8vo. with 24 highly-finished Portraits, cngraved on Steel, 32s.cloth.

STEPHENS.-A MANUAL OF BRITISH COLEOPTERA;

Or, BEETLES : eontaining a Description of all the Species of Beetles hitherto ascertained to inhabit Great Britain and Ireland, ete. By J.F. Stephens, F.L.S. Post Svo.14s. cloth.

STEWAR?.-THE MEANS OF FACILITATING THE TRANSFER OF LAND: Iu Three Lectures. By James Stewart, Esq., of Lincoln's Iun, Barrister. 8vo. 5s. cloth.

THE SUITOR'S INSTRUCTOR IN THE PRACTICE OF THE COUNTY COURTS : containing all the Information necessary for Condueting or Defending a Suit; the Fees payaule on each Step; Definitions of the Legal Terms usect in the Proceedings; an Abstraet of the Act of Parliament; the Rules of Practice, ete. etc. Also a District Directory, yiving the Names of ałt the Streets (and the number of Houses in each Street) which form the Boundaries of the Metropolitan Districts; made from an actual Peranoulation around each: and a List of the Country Districts. By a County Court Assistant Clerk. $12 \mathrm{mo}$. 4s. fid. cloth.

SUMMERLY.-THE SEA AND THE RAILWAY:

Their new Relations set forth in a Jaunt along the Manchester, Sheffield, and Lincolnshire Railway to Grinsby Docks, by Felix Summerly. With Woodcuts by C.W.Cope, A.R.A.; D. Cox, jun.; T. Creswiek, A.R.A.; and R. Redgrave, A.R.A.

[Nearly ready.

\section{SYMONDS.-THE LAW RELATING TO MERCHANT SEAMEN,}

Arranged chietly for the use of Masters and Officers in the Merchant Service. With an Appendix, eontaining the Act 7 \& 8 Vic. e. 112 ; the Regulations under which Lasears may be employed; and soine forms of Proceedings before Mayistrates. By E. W. Symonds, Esq. Chief Clerk of the Thames Police Court. Third Edition. 12mo, 5s. cloth.

TATE.-THE CONTINUOUS HISTORY OF THE LIFE AND WRITINGS OF ST. PAUL, on the basis of the Aets; with Intercalary Matter of Sacred Narrative, supplied from the Fpistles, and elucidated in occasional Dissertations: with the Horar Paulinie of Dr. Paley, in a more correct edition, subjoined. By James Tate, M.A. 8vo. Map, 13s. cloth. 
TAYLER (REV. CHARLES B.)-MARGARET;

Or, the Pearl. By the Rer. Charles B. Tayler, M.A. Rectnr of St. Peter's, Chester, author of "Lady Mary; or, Not of the World;" etc. New Edition. Foolscap Sro. 6s. cloth.

TAYLER (REV.CHARLES B.)-LADY MARY; OR, NOT OF THE WORLD. By the Rev. Cliarles B. Tayler, Rector of St. Peter's, Chester; author of "Margaret. or the Pearl," etc. New Edition. Foolscap Svo. with a Frontispiece engraved by J. Absolon, $6 s .6 d$, cloth.

TAYLOR.-LOYOLA AND JESUITISM. By Isaac Taylor. Post $8 v o$.

[In the Autumn.

\section{TAYLOR (JEREMY).-BISHOP JEREMY TAYLOR'S ENTIRE WORKS:}

With the Life of Bishop Heber. Revised and corrected by the Rev. Charles Page Eden, Fellow of Oriel College, Oxford. Vol. II. (the first in the order of publication) contains the Life of Clurist; Vol. III. the Holy Living and Dying; Vol. IV. a Course of sermous for all the Sundays of the Year. Svo.10s. fid. each, choth.

** To be completed in Ten Volumes, price 10s. 6d. each. Vol. V. containing the Episcopacy, etc. is nearly ready.

\section{THIRLWALL. - THE HISTORY OF GREECE.}

By the Right Rev. the Lord Bishop of St. David's. A new Edition, revised; with Notes. Vols. I. to IV. demy Svo. with Maps, 12s. each cloth. To be completed in 8 volumes.

[Vol. V. is nearly ready.

** Also, an Edition in 8 vols.fcap. Svo. with Vignette Titles, 2l.8s. cloth.

\section{THOMSON'S SEASONS.}

Fdited, with Notes, Philosophical, Classical, Historical, and Bingraphical, by Anthony Todd Thomson, M.D. F.L.S., Professor of Materia Medica and "Therapeutics, and of Forensic Medicine, in University Cottege, Iondon, etc. Fcap.8vo.7s.6d.choth.

\section{THOMSON'S SEASONS.}

Fitited by Bolton Corney, Esq. Illustrated with Seventy-seven Designs drawn on Wood by the Members of the Etehing Club. Engrived by Thompsou and other eminent Engravers. Equare crown Svo. uniforn with "Goldsmith's Poems," 21s. cloth; bound in morocco, by Huyday, $36 s$.

THOMSON.-EXPERIMENTAL RESEARCHES ON THE FOOD OF ANIMALS, AND THE FATTFNING OF CATTLE: with Remarks on the Food of Man. By Robert Dunclas Thomson, M.D. of the University of Giasgrow. Feap. 8ro. 5s. choth.

"The question of the oriuin of the fat of animals appears to be completely resolved by these beautiful and elaborate experiments."-Baron Liebig.

THOMSON (JOINN). - TABLES OF INTEREST.

At Tliree, four, Four-and-a-half, and Five per Cent., from One Pound to Ten Thousand, und from One to Three Hundred and Sixty-five Days, in a regular progression of Single Days; with Interest at all the above Rates, from One to Twetve Months, and from One to Ten Years. Also, Tahles shewing the Fixchange on Bills, etc.etc.etc. By John Thomson, Accountant. New Edition. 12no. Ss. bound.

THOMSON, - THE DOMESTIC MANACEMENT OF THE SICK ROOM, Necessary, in Aid of Medical Treatment, for the Cure of Diseases. By Anthony Todd Thomson, M.D. F.L.S.ctc. New Edition. Post Svo.10s.6d. cloth.

TISCHENDORFF.-TRAVELS IN THE EAST.

By Constantine Tischendorff, Eclitor of the "Codex Fiphrämi Rescriptus," "Codex FridericoAugustanus," etc. Translated from the German by W. E. Shuckard. 16mo. 6s. 6d. chuth.

TONIIINE(BISHOP).-AN INTRODUCTION TO THE STUDY OF THEBIBLE: Being the First Volume of the Elements of Christian Theology; containing Proots of the Autlienticity and Inspiration of the Holy Scriptures; a Summary of the History of the $J$ ews andccount of the Jewish Sects; and abricf Statement of the Contents of the several Books of the Old Testament. By the late George Tomline, D.D.F.R.S. New Edition. Foolscap zro. $5 s .6 d$. cloth.

TOOKE.-THE. HISTORY OF PRICES ;

Wirla reference to the Causes of their principal Variations, from 1792 tn the Present Time. preceded by a sketch of the History of the Corn'Trade in the last J'wo Centuries. By Thomis Tooke, Esq. F.R.S. 3 vols. 8 vo. $2 l$. 8s. choth.

TOOKE.-THE HISTORY OF PRICES,

And of the State of the Circulation, from 1839 to 1847 , inclusirc: with a General Review of the Curreney Question, and Remarks on the Opt ration of the Aet 7 and S Vict. c. 32 : beine a continuation of "The History of Prices from 1793 to 1539." Ly Thomis Tooke, Esa. F.R.S. 8vo. Iss. cloth. 


\section{TOPHANI.-CHEMISTRY MADE EASY,}

For the Use of Agriculturists. By John Topham, A.M. Rector of St. Andrew, St. Mary Witton, and St. Nicholas, Droitwich. New Edition. 16mo. 2s. sewed.

\section{TOWNSEND (CHARLES).-THE LIVES OF TWELVE EMINENT JUDGES}

OF THE LAST AND OF THE PRESENT CENTURY. By W. Charles Townsend, Esq., A.M. Recorder of Macclesfield, author of "Memoirs of the House of Commons." 2 vols. Svo. 28s. cloth.

\section{TURNER.-THE SACRED HISTORY OF THE WORLD,}

Attempred to be Philosophically considered, in a Series of Letters to a Son. By Sharon Turner, F.S.A. and R.A.S.L. Eighth Edition, edited by the Rev, Sydney Turner. 3 vols. post Svo. 31s, 6d. cloth.

\section{TURNER.-THE HISTORY OF ENGLAND,}

From the Earliest Period to the Death of Elizabeth. By SharonTurner, Esq.F.A.S.R.A.S.L.

New Editiens, 12 vols. Svo. $87.3 s$. efotli; or, separately-

THE HISTORY of the ANGLO-SAXONS. 3 vols. 8 vo. $2 l .5 s$.

THE HISTORY of ENGI,AND during the MIDDLE AGES. 5 vols. 8vo. 37.

THE HISTORY of the REIGN of HENRY VIII. 2 vols. 8vo.26s.

THE REIGNS of EDIVARD VI., MARY, and ELIZABETH. 2 vols.8vo.32s.

TURTON'S (DR.) MANUAL OF THE LAND AND FRESHWATER SHELLS OF THE BRITISH ISLANDS. A new Edition, thoroughly revised, with Additions. By John Edward Gray. Post Sro. with Woodcuts, and 12 coloured Plates, I5s. cloth.

TWELVE YEARS ACO :

A 'rile. By the Author of "Letters to My Unknown Friends." Foolscap 8vo. 6s. 6d. cloth.

TWISS,-ON THE RELATIONS OF THE DUCHIES OF SGHLESWIG AND HOLSTEIN TO THE CROWN OF DENMARK AND THE GFRMANIC CONFEDERA. TION, and on tle Treaty-Engagements of the Great Furopean Powers in reference thereto. By Travers Twiss, D.C.L. H.R.S., Fellow of University College, Oxford, and Adrocate in Doctors Commons. 8vo.6s.6d. cloth.

TWISS-VIEW OF THE PROGRESS OF POLITICAL ECONOMY IN EUROPE SINCF THE SIXTEENTH CENTURY: being a Course of Lectures delivered lefore the University of Oxford, in Michaelmas Term 1846, and Lent Term IS47. By Travers Twiss, D.C.L. F.R.S. Professor of Political Economy, and Fellow of University College, Oxford. 8vo. 10s.6d. cloth.

URE.-DICTIONARY OF ARTS, MANUFACTURES, AND MINES:

Containing a clear Expusition of their Principles and Practice. By Audrew Ure, M.D. F.R.S. M.G.S.M.A.S. Lond.; M. Acad. N.S. Philid.; S. Pl..Soc.N. Germ. Harov.; Mullii, etc.etc. 3d Fdition, eorrected. 8vo. with 1,240 Woodeuts, 50s. cloth.

By the same Author,

SUPPLEMENT OF RECENT IMPROVEMENTS. 2̇d Edition. 8vo. 14s. cloth.

VON ORLLCH (CAPT.)-TRAVELS IN INDIA,

And the adjacent Countries, in 1842 and 1843. By Capt. Leopold Von Orlieh. Translated from the German by H. Fvans IJloyd, Esq. 2 vols. 8vo. with coloured Frontispieces, and numerous Illustrations on Wood, 2ús. cloth.

WALFORD (J.E.)-THE LAWS OF THE CUSTOMS,

Compiled by Direction of the Lords Commissioners of Her Mijesty's Treasury, and pubIished under the Sanction of the Commissioners of Her Majesty's Customs; witl Notes and a General Index. Edited hy J.G. Walford, Esq. Solicitor for the Customs. Printed for Her Majesty’s Stationery Office, and published by Authority. 8vo. I0s.6d. cloth.

WALKER.--ELEMENTA LITURCICA;

Or, the Churchman's Primer, for the Scholastic Study of the Book of Common Prayer. By G. A. Walker, A.M , of Christ College, Cambridge. New Edition, entircly rearranged and eonsiderably ellarged. Feap. 8 vo. $48.6 d$. cloth.

WALKER (GEO.)-CHESS STUDIES :

Comprising 1,000 Games actually Played during the last Half Century ; presenting a unique Colleetion of Classical and Brilliant Specimens of Chess sikill in cvery stave of the Gane, and forming an Eucyclopedia of Rcference. By George Walker. Svo. I0s. 6d. sewcd. 
WARDLAW.-DISCOURSES ON THE PRINCIPAL POINTS OF THE SOCINIAN CONTROVEIRSY-the Unity of God, and the Trinity of Persous int the Godhead-the Supreme Divinity, of Jesus Christ-the 1)octrine of the Atonement, - the Christian Character, etc. By Ralph Wardlaw, D.P. New Edition. 8vo.15s. cloth.

\section{WATERTON.-ESSAYS ON NATURAL HISTORY,}

Chiefly Orrithology. By' Charles Waterton, Esq., author of "Wanderings in South Ameriea." With an Autobiograply of the Author, and a View of Walton Hall. New Edition. Foolscap 8vo. 8s. cloth.

SECOND SFRIES. With Continuation of Mr. Waterton's Autobiography. New Edition. Feap. 8vo. with Vignette by T. Creswick, A.R.A. $6 s .6 d$. eloth.

\section{WEBSTER.-AN ENCYCLOPAEDIA OF DOMESTIC ECONOMY ;}

Comprising such subjects as are most immediately connected with Housekeeping; as, The Cunstruetion of Domestic Fdificts, with the Modes of Warming, Ventilating, and Lighting them-A Description of the various Articles of Furniture, with the Nature of their Materials-Dnties of Servants, etc.etc. By Thomas Webster, F.G.S., etc. ete.; assisted by the late Mrs. Parkes. New Edition. 8vo. with nearly 1,000 Woodeuts, 50s. eloth.

WESTWOOD (J.OO.) -AN INTRODUCTION TO THE MODERN CLASSIFICATION OF INSECTS ; founded on the Natural Habits and comparative Organisation of the different Families. By J. O. Westwood, F. L.S. etc. 2 vols. 8vo, with numerous Illustrations, $2 l .7 s$. cloth.

WILBERFORCE (W.) - A PRACTICAL VIEW OF THE PREVAILING RELIGIOUS SYSTEMS OF PROFESSED CHRISTIANS, in the Higher and Middle Classes in this Country, contrasted with Real Christianity. By William Wilberforce, Esq. M.P. for the County of York. New Editions. 8vo. 8s. boirds. 12mo. 4s.6d. eloth.

\section{WILSON.-THE LANDS OF THE BIBLE VISITED AND DESCRIBED,}

In an Extensive Journey undertaken with speeial referenee to the Promotion of Biblieal Researeh and the Advancement of the Cause of Philan thropy. By John Wilson, D.D. F.R.S. Howorary I'resident of the Bombay Braneh of the Royal Asiatic Society, ete. 2 vols. 8vo. with Maps and numerous Illustrations, 1l. 16s. eloth.

WILLOUGHBY (LADY)-SO MUCH OF. THE DIARY OF LADY WILLOUGHBY as relates to her Domestic History, and to the Eventful Period of the reign of King Charles the First (1635 to 1648). Produced in the style of the perjod to which "The Diary" refers. New Edition. Square foolscap 8vo. 8s. boards; or 18s. bound in morocco (by Hayday).

WILLOUGHBY (LADY).-SOME FURTHER PORTIONS OF THE DIARY OF LADY IVILLOUGHBY, which do rclate to her Domestie History, and to the Stirring Fivents of the latter years of the reign of King Charles the First, the Protectoratc, and the Restoration (1648 to 1663). New Edition. Square foolscap 8vo. 8s.boards; moroeco, $18 s$. (bound by Hayday).

\section{WINTER (J. W.)-THE HORSE IN HEALTH AND DISEASE:}

Or, Suggestions on his Natural and General History, Varieties, Conformation, Paees, Age, Soundness, Stabling, Condition, Training. and Shoeing. With a Digest of Veterinary Practiee. By James IV. Winter, M.R.C.V.S.L. 8vo. 10s.6d. eloth.

\section{WOOD - A PRACTICAL TREATISE ON RAILROADS,}

And Interior Communication in General; containing numerous Experinents on the Powers of the Improved Locomntive Engines, and Tables of the comparative Cost of Conveyance on Canals, Railvays, and Turnpike Roads. By Niclolas Wood, Memb. Inst. Civ. Eng. ete. 3d Edition. Svo. with Plates and Woodeuts, 3is. 6d. cloth.

\section{WOODWARD.-ESSAYS AND SERMONS.}

By the Rev. Henry Woodward, M.A., formerly of Corpus Christi College, Oxford, Rector of Fethard, in the Diocese of Cashel. New Edition. 2 vols, fcap.8vo. 14s. cloth.

WOODWARD.-A SEQUEL TO THE SHUNAMMITE:

Being a Series of Reflections on 2 Kings iv. 17-35. By the Rev. Henry Woodward, M.A., Reetor of Fethard, in the Diocese of Cashel, and formerly of Corpus Christi College, Oxford. Fcap. 8vo.6s. cloth.

\section{ZUMP'T (PROF.) - A GRAMMAR OF THE LATIN LANGUAGE.}

By C. G. Zumpt, Ph. D. Professor in the University, and Member of the Royal Aeademy of Berlin. Translated from the gtll Erlition of the original, and adapted to the use of English Students, by Leonhard Schmitz, Ph. 1)., Rector of the High School of Edinburgl ; with numerous Additions and Corrections by the Author. New Edition. 8vo.14s. cloth.

[August 31, 1848. 


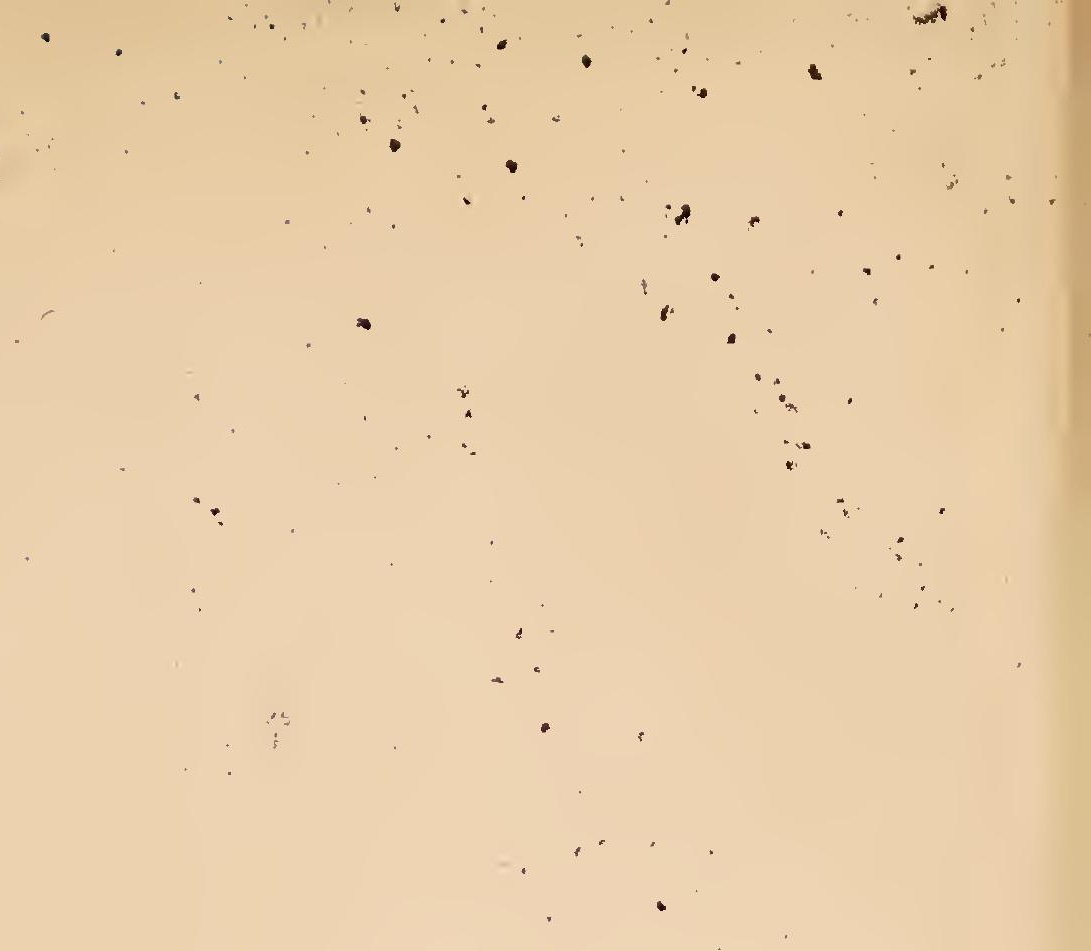




